San Jose State University

SJSU ScholarWorks

Master's Projects

Master's Theses and Graduate Research

Spring 2011

\title{
An Evaluation of the City of Palo Alto's California Avenue Pedestrian And Transit-Oriented Development (PTOD) Combining District Regulations
}

Scott Alexander McKay

San Jose State University

Follow this and additional works at: https://scholarworks.sjsu.edu/etd_projects

Part of the Urban Studies and Planning Commons

\section{Recommended Citation}

McKay, Scott Alexander, "An Evaluation of the City of Palo Alto's California Avenue Pedestrian And TransitOriented Development (PTOD) Combining District Regulations" (2011). Master's Projects. 225.

DOI: https://doi.org/10.31979/etd.ng4u-pqmv

https://scholarworks.sjsu.edu/etd_projects/225

This Master's Project is brought to you for free and open access by the Master's Theses and Graduate Research at SJSU ScholarWorks. It has been accepted for inclusion in Master's Projects by an authorized administrator of SJSU ScholarWorks. For more information, please contact scholarworks@sjsu.edu. 
AN EVALUATION OF THE CITY OF PALO ALTO'S CALIFORNIA AVENUE PEDESTRIAN AND TRANSIT-ORIENTED DEVELOPMENT (PTOD) COMBINING DISTRICT REGULATIONS

Scott Alexander McKay

May 16, 2011

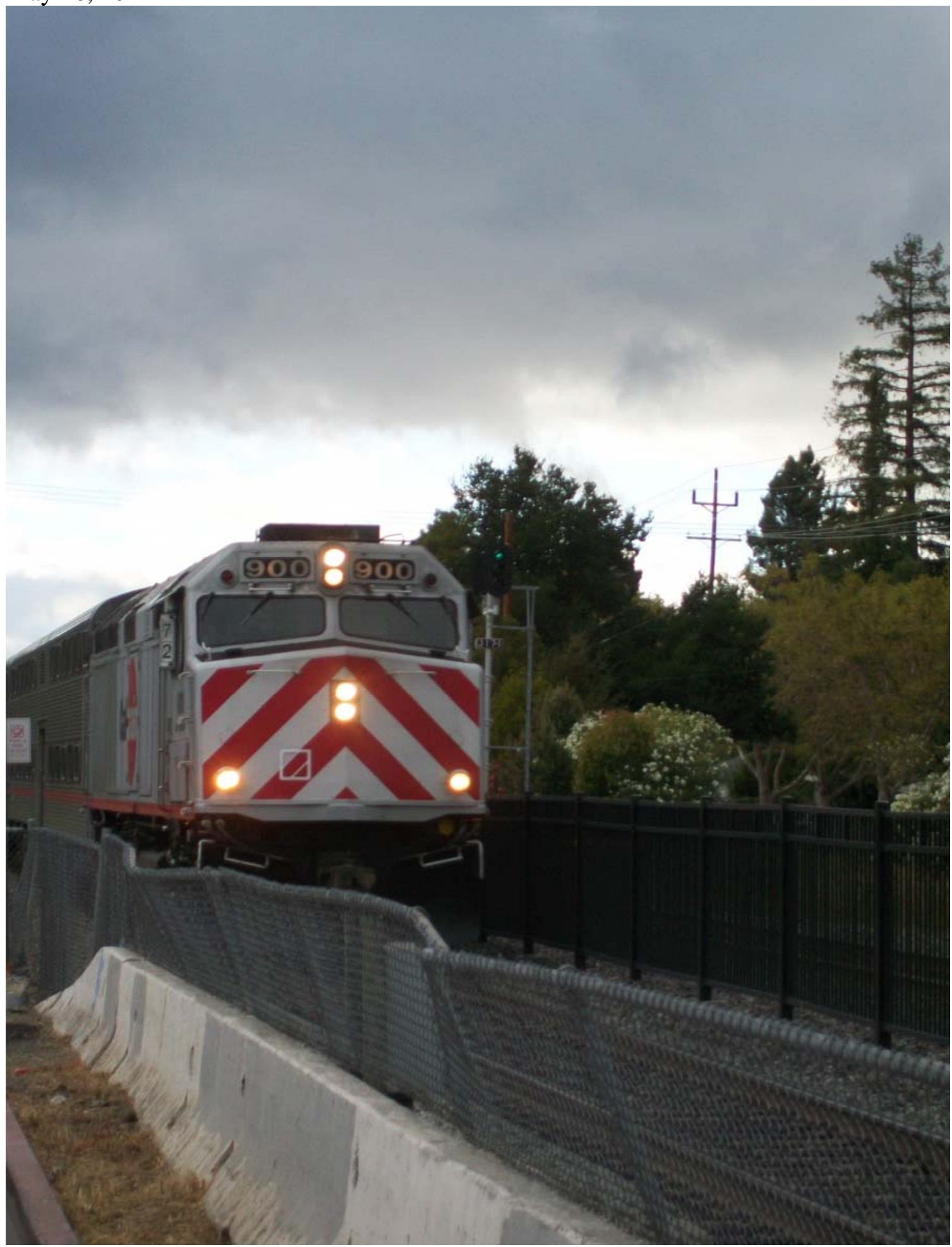

Photograph by author. 



\title{
AN EVALUATION OF THE CITY OF PALO ALTO'S CALIFORNIA AVENUE PEDESTRIAN AND TRANSIT-ORIENTED DEVELOPMENT (PTOD) COMBINING DISTRICT REGULATIONS
}

\author{
A Planning Report \\ Presented to \\ The Faculty of the Department of \\ Urban and Regional Planning \\ San José State University \\ In Partial Fulfillment \\ Of the Requirements for the Degree \\ Master of Urban Planning \\ By \\ Scott Alexander McKay
}

May 2011 


\section{ACKNOWLEDGMENTS}

I would like to express my gratitude to all of my coworkers who shared their institutional knowledge with me through in-depth interviews. Without this information, it would have been nearly impossible to understand the complete picture of the city's PTOD regulations. Also I wish to thank the City of Palo Alto itself, which has treated me so well during the past four years while I worked full time and attended night courses to make my dream of a master's degree a reality.

I would also like to thank my mother and brother for providing the family support which has helped me through the past five years, during which I have experienced both the highest and lowest points of my life. Dad, I thank you for placing such a high value on education and encouraging me to pursue my master's degree. I am glad you were able to see me get started; I only wish you were here to read the final product; R.I.P.

Last and certainly not least, I would like to thank my fiancé who has provided support and encouragement to me throughout the past five years. You have been an inspiration to me and everyone who knows you, despite enduring such senseless tragedy. I know your parents would be proud of your accomplishments and the woman you have become.

With the completion of this research report and attainment of my master's degree, I look forward to using the knowledge I have gained to work toward a more sustainable and equitable future for my community and society as a whole. I am excited about the prospect of having more time to spend with my family and friends and also on improving my health.

\section{Persistence}

"Nothing in the world can take the place of persistence. Talent will not; nothing is more common than unsuccessful men with talent; genius will not; unrewarded genius is almost a proverb. Education will not; the world is full of educated derelicts. Persistence and determination alone are omnipotent. The slogan press on has solved and always will solve the problems of the human race."

- Calvin Coolidge 


\section{TABLE OF CONTENTS}

LIST OF TABLES ….................................................................................. vii

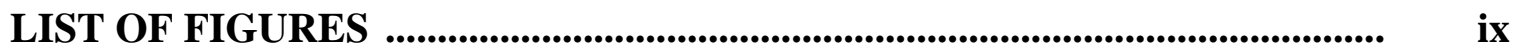

CHAPTER 1: INTRODUCTION ................................................................. 1

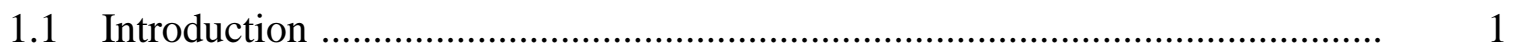

1.2 Background ........................................................................................

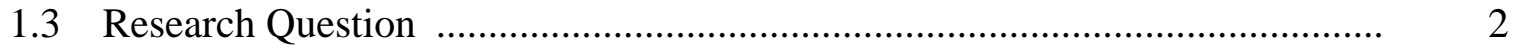

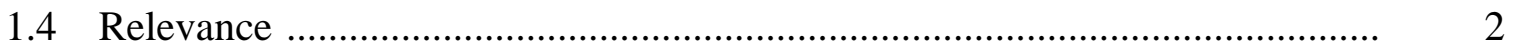

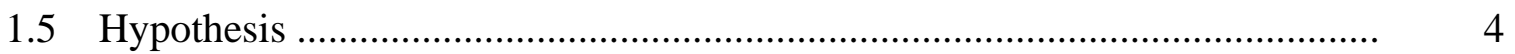

1.6 Methods ...................................................................................... 5

1.7 Overview of the Report .................................................................................

CHAPTER 2: LITERATURE REVIEW ..................................................... 9

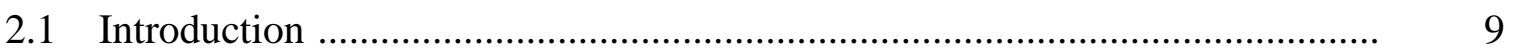

2.2 Main Themes and Debates ....................................................................... 10

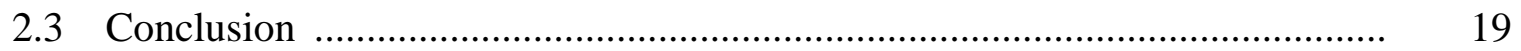

\section{CHAPTER 3: CURRENT STATUS OF STATE AND REGIONAL \\ AGENCY'S TOD POLICIES AND PROGRAMS ............................................ 21 \\ $3.1 \quad$ Introduction ......................................................................................... 21 \\ 3.2 California Air Resources Board (CARB) ……………………………….... 21 \\ 3.3 Metropolitan Transportation Commission (MTC) ………………………….. 23 \\ 3.4 Association of Bay Area Governments (ABAG) .......................................... 24 \\ 3.5 Bay Area Air Quality Management District (BAAQMD) ............................. 25 \\ 3.6 Palo Alto Transit Operators ......................................................................... 26}

CHAPTER 4: PALO ALTO HISTORY ..................................................... 29

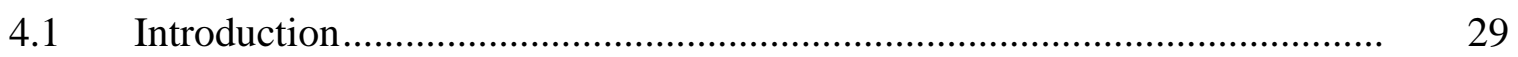

$4.2 \quad$ Mayfield ......................................................................................... 29

$4.3 \quad$ Leland Stanford.................................................................................... 34

$4.4 \quad$ Palo Alto ......................................................................................... 35

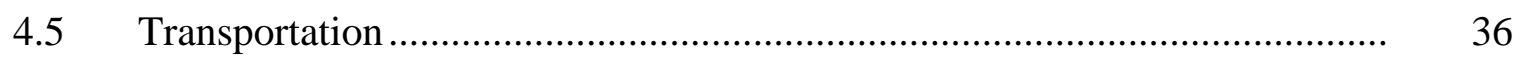

4.6 Growth and Industry ............................................................................. 39

CHAPTER 5: EXISTING POLICIES AND REGULATIONS............................... 41

$5.1 \quad$ Introduction..................................................................................... 41

$5.2 \quad$ Comprehensive Plan ................................................................................... 41

5.3 Evaluation of Comprehensive Plan Goals, Policies, and Programs............... 42

$5.4 \quad$ Housing Element Update .............................................................................. 48

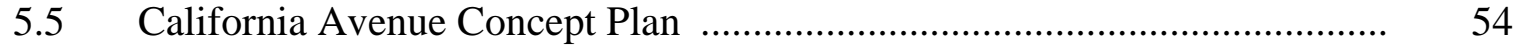

5.6 Zoning Ordinance Update: History of PTOD Regulations............................. 58

$5.7 \quad$ Review of Chapters 18.34 (PTOD) and 18.52 (Parking)................................. 63

$5.8 \quad$ Current PTOD Project and Topics.................................................................. 67 
$5.9 \quad$ Affordable Housing Requirements ……………………………………...... 69

5.10 City of Palo Alto Staff Members Interviewed for this Report ....................... 72

CHAPTER 6: FINDINGS, RECOMMENDATIONS, AND

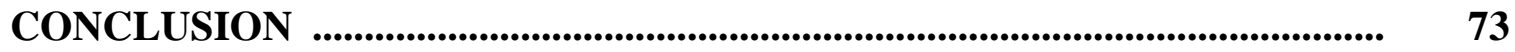

$6.1 \quad$ Findings ......................................................................................... 76

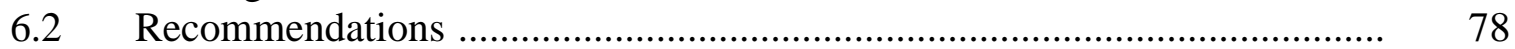

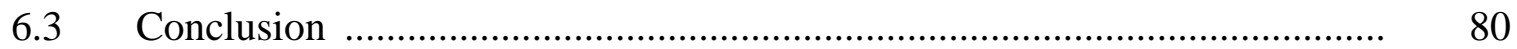

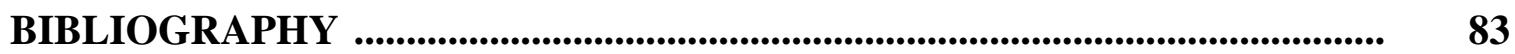

APPENDIX 1: CALIFORNIA AVE. PTOD DISTRICT BOUNDARY

MAP

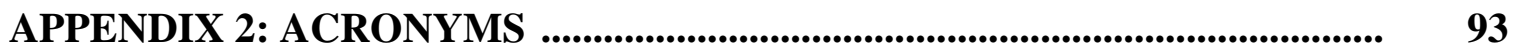

APPENDIX 3: IN-PERSON INTERVIEW QUESTIONS .................................... 95 


\section{LIST OF TABLES}

TABLE 1. Permitted and Conditionally Permitted Land Uses - California

Avenue

64

TABLE 2. Development Standards for the California Avenue PTOD District ....... 65

TABLE 3. Minimum Off-Street Parking Requirements - California Avenue ......... 66 


\section{LIST OF FIGURES}

Figure 1: Public art murals on the wall of a pedestrian alley on California Avenue in Palo Alto

Figure 2: Public art mural on the wall of Country Sun Natural Foods on California Avenue in Palo Alto

Figure 3: Public art mural on the wall of Antonio's Nut House on California Avenue in Palo Alto

Figure 4: Public art mural depicting the old Mayfield station on the wall of a building on California Avenue in Palo Alto

Figure 5: Public art in underground pedestrian tunnel leading to the California Avenue station in Palo Alto

Figure 6: View of California Avenue Caltrain station with pedestrian tunnel entrance in foreground

Figure 7: View looking down California Avenue from the Caltrain station toward El Camino Real

Figure 8: Palo Alto Central mixed-use development abutting the California Avenue Station 



\section{CHAPTER 1: INTRODUCTION}

\subsection{Introduction}

The audience for whom this planning report is written includes elected City of Palo Alto decision makers and officials such as members of the Palo Alto City Council, the Palo Alto Planning and Transportation Commission, and the Palo Alto Architectural Review Board. The audience also includes the Palo Alto City Manager, Palo Alto Planning and Community Environment Department staff, and staff members from other city departments that deal with development review and field questions from the public. The audience also includes architects, developers, and realtors, and ultimately the citizens of the City of Palo Alto and anyone else with an interest in transit-oriented development. A list of acronyms used in this report is located in Appendix 2.

\subsection{Background}

The main purpose of this study is to recommend how the City of Palo Alto should revise its California Avenue Pedestrian and Transit-Oriented Development (PTOD) Combining District regulations to more effectively support public transit use and provide a wider variety of housing types, commercial, retail, and limited office uses. The California Avenue area will play an important role in how the City of Palo Alto plans for future housing growth. By revising the PTOD regulations, the City of Palo Alto can ensure that development in the area is most effective at meeting the stated purposes of the district.

On October 11, 2006, City of Palo Alto Ordinance \#4914 added chapter 18.34 (Pedestrian and Transit-Oriented Development [PTOD] Combining District Regulations) to the City of Palo Alto's Municipal Code (PAMC). The purpose of the PTOD regulations are to encourage mixed-use development that includes residential and another use or combination of uses. The PTOD regulations allow a greater flexibility of uses to encourage the provision of a variety of higher-density housing types such as apartments and condominiums. The PTOD regulations also seek to increase public transportation use by making the area more attractive and usable for pedestrians and bicyclists.

The intent of the PTOD regulations are that a variety of housing types will be built above ground-floor commercial and retail uses, and that office uses are restricted to floors other than the ground floor. The goal is to create a vibrant streetscape and to provide services to the people who live and work in the neighborhood. Office uses are not allowed on the ground floor to ensure that street-level tenant spaces are free for commercial or retail uses.

There are six stated purposes of the PTOD regulations. However, for this planning report, the focus of the evaluation and recommendations are on the first two only: (1) support use of public transportation and (2) encourage a variety of housing types, 
commercial, retail, and limited office uses. ${ }^{1}$ The City of Palo Alto’s PTOD Combining District Regulations have been in effect for almost five years. Lately, there has been increased interest in the development potential of properties located in the PTOD Combining District. However, to date, only two applications for projects have been submitted to the city.

\subsection{Research Question}

How should the City of Palo Alto revise its California Avenue Pedestrian and Transit-Oriented Development (PTOD) Combining District regulations to more effectively support public transit use and provide a wider variety of housing types, commercial, retail, and limited office uses?

\subsection{Relevance}

The research question examined in this planning report is an important one to study for several reasons. Transit-oriented development (TOD) is a top solution to many of the environmental and planning-related problems facing urban residents and society as a whole. The social, economic, and environmental benefits of TOD are widely publicized and acknowledged. ${ }^{2}$ Cities, counties, and state agencies in California and across the country are increasingly acknowledging TOD as an important form of sustainable development.

Most local (city and county) governmental jurisdictions control land use through the administration of zoning codes. Zoning codes are the primary tool through which local jurisdictions implement their community's general plan (called a Comprehensive Plan in Palo Alto's case), which contains a vision or policies on future growth and development. ${ }^{3}$ Through the application of zoning laws, local governments may initiate special transit-oriented zones or combining districts. Local governments have the responsibility to act if they hope to solve many of the problems that afflict rapidly urbanizing areas. The increased awareness of TOD's benefits by municipalities has been further validated by the proliferation of TOD zoning districts, policies, and incentives.

The problems that TOD seeks to address are many of the widely acknowledged ills of modern society. "The transit-oriented market segments currently exhibit travel behaviors that are environmentally friendly. They walk more and take transit much more than any of the other market segments." 4 TOD holds promise in addressing a variety of

\footnotetext{
${ }^{1}$ City of Palo Alto, Title 18.34 of the Palo Alto Municipal Code: Pedestrian and Transit-Oriented Development Combining District Regulations, (2006), 1.

${ }^{2}$ California Department of Transportation, Statewide Transit-Oriented Development Study: Factors for Success (2002), 22.

${ }^{3}$ Robert Cervero, "Transit-Oriented Development in the United States: Experiences, Challenges, and Prospects,” Transit Cooperative Research Program 102 (2004), 63.

${ }^{4}$ Karla H. Karash et al., "Understanding How Individuals Make Travel and Location Decisions: Implications for Public Transportation,” Transit Cooperative Research Program 123 (2008), 7.
} 
issues including traffic congestion, climate change, housing affordability, and a shifting demographic away from the single-family detached housing model. The single-family detached housing model came into prominence during the post-war era of the 1940s and 1950s and has been the dominant form ever since. The form originated at a time of housing shortages, low gasoline prices, and major federal investment in the interstate highway system. ${ }^{5}$ Under these circumstances, the single-family detached housing model was an immediate success.

Unfortunately, the unforeseen consequences of the sprawling single-family housing form are common to many regions of the country that were developed or built during the post-war years. The suburban form, which is almost exclusively based on the automobile, dominates. Fortunately, TOD offers a viable alternative for households who do not wish to own a car. In fact, "TOD households are twice as likely to not own a car, and own roughly half as many cars as comparable households not living in TOD.," data on TOD households and car ownership clearly shows a preference for non-automobile-based mobility options. Transit-oriented development provides a method by which some communities may be able to transition to a more sustainable transit- and pedestrian-oriented development pattern.

While many of the regions of the country that were developed during this era share similar problems, the solutions are not always as clear. On the surface, TOD makes sense; but what does it really mean for a specific community? Certainly there are different approaches or components of TOD that are better suited for particular communities. For example, many cities, when setting the boundaries for a TOD district, use one-quarter mile as a default. But choosing a one-quarter-mile buffer for the boundary of a TOD district may not be appropriate. This is because in some cases, substantial shares of pedestrian travel (perhaps one-quarter to one-third mile) exceed the often-cited threshold of one-quarter mile. ${ }^{7}$ Therefore, local governments may have greater success with TOD districts if studies are done to determine the pedestrian travel patterns of the population prior to setting the boundaries. Just because a specific TOD project component, such as a distance-based boundary, was a success for one city or community does not mean that it should be arbitrarily applied in another city.

Cities and counties are increasingly supporting TOD by creating new regulations and development standards that set guidelines for the redevelopment of station areas. ${ }^{8}$ In October 2006, the City of Palo Alto enacted an ordinance that established the California Avenue PTOD Combining District on parcels within approximately 2,000 feet of the California Avenue Caltrain train station (see Appendix 1: California Avenue PTOD

\footnotetext{
${ }^{5}$ Sara J. Hendricks and Julie Goodwill, "Building Transit-oriented Development in Established Communities,” National Center for Transit Research (2002), 3.

${ }^{6}$ G. B. Arrington and Robert Cervero, "Effects of TOD on Housing, Parking, and Travel," Transit Cooperative Research Program 128 (2008), 29.

${ }^{7}$ Michael Iacono, Kevin Krizek, and Ahmed El-Geneidy, “Access to Destinations: How Close is Close Enough? Estimating Accurate Distance Decay Functions for Multiple Modes and Different Purposes,” Minnesota Department of Transportation (May 2008), 12.

${ }^{8}$ Aseem Inam, Jonathan Levine, and Richard Werbel, “Developer-Planner Interaction in Transportation and Land-use Sustainability,” Mineta Transportation Institute 01-21 (June 2002), 16.
} 
District Boundary Map). The PTOD regulations have six stated purposes that are listed in the ordinance. While the ordinance includes development standards for new buildings in the district, there is considerable flexibility in the specific transit-oriented components that individual projects can employ.

Successfully implemented TOD has the potential to greatly support the use of public transit and increase the variety of housing types in an area. However, a carelessly applied cookie-cutter approach to TOD may result in unintended and sometimes undesirable results. It is important to understand which components of TOD are appropriate for Palo Alto's unique conditions, to ensure that the right ones are chosen specifically for the California Avenue area. There have been many evaluations of individual TOD projects, districts, and regulations. This research paper is unique from other TOD evaluations and reviews because it will focus specifically on the City of Palo Alto’s PTOD regulations. Few studies, if any, evaluate or review Palo Alto's PTOD regulations.

\subsection{Hypothesis}

The City of Palo Alto’s PTOD Combining District regulations were a good first step toward implementing TOD in the California Avenue area; however, there is more that should be done. Specifically, the City of Palo Alto should revise its PTOD regulations to further support the use of public transportation and to further encourage a variety of housing types, commercial, retail, and limited office uses. By revising the PTOD regulations, Palo Alto can ensure that all future development in the California Avenue area works toward addressing the city’s housing needs while providing access and support to high-quality transit services.

For example, Chapter 18.34.040(d) of the PAMC describes Parking Adjustments, to the required parking standards, but they may not go far enough. "A primary reason for higher TOD transit use is self-selection. Current transit users and those precluded to use transit seek out TOD."9 This results in a high number of people who walk and use transit choosing to live in TOD. If people who live in TOD use transit and walk to get around, what is the proper amount of parking to require? This question takes on increased importance when we acknowledge the cost that additional parking spaces add to development. Why should residents of TOD be required to pay for parking spaces (through increased rent or purchase price) that they do not want or need? The City of Palo Alto should amend its PTOD regulations Parking Adjustments section to allow additional reductions in required parking. This will further support the use of public transportation (e.g., Caltrain, bus, and shuttle service).

Another way in which Palo Alto's PTOD regulations could be improved is by further encouraging the provision of housing for older adults. According to the Association of Bay Area Governments (ABAG), the median age of Bay Area residents

\footnotetext{
${ }^{9}$ Arrington and Cervero, "Effects of TOD on Housing, Parking, and Travel,” 2.
} 
will increase by approximately six years by $2035 .^{10}$ This represents a significant increase in older adults, with the 60-70, 70-80, and over 80-year-old age cohorts increasing considerably. Older adults drive less and use transit more than the population as a whole. They need fewer parking spaces, do not have as large an impact on some city services like schools, and could benefit from the close proximity of the PTOD district to Stanford University's medical facilities and services. The city should encourage the provision of housing for older adults in the California Avenue PTOD District.

Additional incentives should be made available to encourage a variety of housing types, commercial, retail, and limited office uses. By providing a variety of housing types, a wider range of income levels can be accommodated than when compared to a more homogeneous single-family detached housing form. ${ }^{11}$ By providing additional incentives and reduced parking requirements, developers may be more likely to build smaller units. Local governments and their elected decision makers are ultimately responsible for deciding how to accommodate the appropriate range of income levels. ${ }^{12}$ Local governments have the authority to regulate land use and enact development standards for areas under their jurisdiction. Local governments have the duty and responsibility to use the tools at their disposal (specifically zoning) to address and adapt to changing conditions.

\subsection{Methods}

There were three methods used for the research in this paper: (1) a review of published literature and studies on TOD; (2) a review of City of Palo Alto's PTOD policies, programs, and regulations; and (3) interviews of City of Palo Alto staff.

\section{(1) Researched published literature and studies on TOD.}

(a) Data sources: Data was collected from peer-reviewed and non-peerreviewed journal articles, reports, reviews, and websites.

(b) Reason for collecting the data: The data collected through this research provided examples of best practices of TOD that may be appropriate for the City of Palo Alto.

(c) Data collection procedures: Data was collected from online databases including, but not limited to Melvyl, Transportation Research Board (TRB), Transportation Research Information Service (TRIS), and others available through the SJSU library catalogs and on the web.

\footnotetext{
${ }^{10}$ Association of Bay Area Governments, “ABAG Projections 2007: Executive Summary,” Association of Bay Area Governments, http://www.abag.ca.gov/planning/currentfcst/summary1.html (accessed January 15, 2009).

${ }^{11}$ California Department of Transportation, Statewide Transit-Oriented Development Study, 30.

${ }^{12}$ Cervero, “Transit-Oriented Development in the United States,” 63.
} 
(d) Method of data analysis: Based on information that was obtained during the literature review, data was grouped into categories that may be applicable to the City of Palo Alto's California Avenue PTOD Combining District. Best practices of TOD, as identified by expert literature, were also used to categorize the data.

\section{(2) Reviewed the City of Palo Alto's PTOD policies, programs, and regulations.}

(a) Data sources: Data was collected from the City of Palo Alto Municipal Code (PAMC) Chapter 18, the City of Palo Alto's Comprehensive Plan, and other city reports and documents.

(b) Reason for collecting the data: The data was collected to understand the City of Palo Alto's current PTOD regulations. The City of Palo Alto's Comprehensive Plan was reviewed for relevant information on TOD, housing, transportation, and land-use policies and programs. The City of Palo Alto's Comprehensive Plan also provided information that was used to inform decisions about recommendations for improvements to the PTOD regulations.

(c) Data collection procedures: Documents such as Chapter 18 of the PAMC, area plans, and the City of Palo Alto Comprehensive Plan were located and reviewed.

(d) Method of data analysis: Current city policies and programs were reviewed in regards to their desired outcomes. Some general topics that were reviewed include: land use, transportation, and housing policies and programs, as well as development standards including parking requirements and floor area ratios. This information served as a starting point to determine what has been successful in the past and to inform recommendations for future changes.

\section{(3) Conducted interviews of city staff.}

(a) Data sources: Data was collected by interviewing the following City of Palo Alto staff members: Curtis Williams, Steve Staiger, Roland Rivera, Elena Lee, Clare Campbell, and Ronlando Babiera.

(b) Reason for collecting the data: The data was collected to understand the historical perspective of the City of Palo Alto's PTOD Combining District and Comprehensive Plan, as well as to gather information on the two documents' perceived successes and failures. The data will be used to inform recommendations for future policy revisions. 
(c) Data collection procedures: In-person interviews were conducted. Refer to Appendix 3 for in-person interview questions.

(d) Method of data analysis: Qualitative summaries of the city staff members' answers were used to identify common themes, as well as perceived successes and failures of the comprehensive plan's policies and programs and the PTOD regulations. This information was synthesized to determine findings and recommendations of how the City of Palo Alto's Comprehensive Plan and PTOD regulations should be changed.

\subsection{Overview of the Report}

This report includes a total of six chapters. The first chapter provides a brief history of the City of Palo Alto's PTOD Combining District regulations as well as a discussion of the research question, its relevance, and the methods employed to answer the research question. The second chapter is the literature review, which describes the main themes and debates surrounding TOD. The third chapter is a review of the current status of various state and regional agencies' TOD policies and programs. The fourth chapter discusses Palo Alto's history including transportation, growth, and industry. The fifth chapter explores the City of Palo Alto's various policies and regulations that deal with TOD. The sixth chapter provides findings, recommendations, and concludes the report. 


\section{CHAPTER 2: LITERATURE REVIEW}

\subsection{Introduction}

The practice of strategically locating development along travel routes has been in use since the earliest human settlements were placed along intersections of trails, roads, and trade routes. Development was planned at these crossroads for many of the same reasons that modern transit-oriented development is endorsed today: higher land values, decreased travel distances, and better access to destinations. While at the present time TOD refers to more recent developments in the field (past 20+/- years), it is easy to see parallels from history (e.g., the early streetcar suburbs and the suburban single-family residential communities that sprang up along the interstate highway system).

Today, when planners talk about TOD, they are speaking specifically about higher-density, mixed-use development that provides access to a transit station or stop. TOD is a popular topic in the planning field because it holds enormous potential for the realization of many of the profession's ideals, such as a reduction in environmental impacts through a more socially equitable development form. As such, there is a constantly evolving body of knowledge and studies on the topic that in many areas agree and form consensus, but in others show there is still much that is unknown.

This literature review attempts to synthesize the main themes and debates in thirty-nine studies which examined TOD. The Main Themes and Debates section is subdivided into the five following thematic areas:

1. Do land-use planning and increased density facilitate successful TOD?

2. Does TOD increase land values?

3. Does TOD decrease environmental impacts?

4. Does TOD have lower trip generation rates?

5. Does TOD increase affordable housing opportunities?

The Conclusion section of the literature review summarizes these five main themes and debates and suggests areas where future research may be needed. 


\subsection{Main Themes and Debates}

\subsubsection{Do land-use planning and increased density facilitate successful TOD?}

The first stage of transit-oriented development is usually a plan at the local level. Most cities produce a guiding policy document called a general plan. This policy document sets out goals, policies, and programs for the city and sets guidelines for future growth. Most cities also have a zoning ordinance within their municipal code that prescribes permitted and conditionally permitted uses, and provides specific development standards for new development. The development standards must be followed in order to ensure development is consistent with the city's stated goals, policies, and programs. Many cities have adopted policies that identify or endorse TOD as a desirable form. However, many have not, and most could still use work revising their specific development standards to ensure they will result in the desired policy outcomes.

In this report, thirteen studies were reviewed, which evaluated the various ways in which regulatory policies affect land-use planning and the building of successful TOD. More specifically, Cervero, Badoe and Miller, Renne, Karash et al., and Chatman all agreed that the density and mixture of land uses influenced rates of car ownership and use, transit use, and mode share. ${ }^{13}$ For example, when car ownership and frequency of use decreased, transit and non-auto mode shares increased. There was a clear consensus among the studies that pointed to this conclusion. However, two of the authors went further by conditioning their findings. Chatman explained building density will have an insignificant influence on travel unless level of service (LOS) standards and parking requirements are reduced or eliminated. ${ }^{14}$ Badoe and Miller referred to other studies that showed the impacts of density and land-use mix, on car ownership and use, transit use, and mode share, to be weak. The weakness was primarily attributed to gaps in our understanding of the interactions, and methodological and data limitations. ${ }^{15}$ It is understandable that under varying circumstances, the results may not always be similar. Overall, the general consensus is that regulatory policies positively contribute to the development of successful TOD.

While local governments and communities generally support TOD, most scholars agree there are a variety of views on the best methods to formulate and implement

\footnotetext{
${ }^{13}$ Robert Cervero, "Built Environments and Mode Choice: Toward a Normative Framework," Transportation Research D 7 (2002): 265-284; Daniel A. Badoe and Eric J. Miller, “Transportation LandUse Interaction: Empirical Findings in North America, and their Implications for Modeling," Transportation Research D 5 (2000): 235-263; John L. Renne, "From Transit-Adjacent to Transit-Oriented Development,” Local Environment 14 (January 2009): 1-15; Karash et al., "Understanding How Individuals Make Travel and Location Decisions,” 1-147; D.G. Chatman, "Deconstructing Development Density: Quality, Quantity and Price Effects on Household Non-Work Travel,” Transportation Research A 42 (2008): 1008-1030.

${ }^{14}$ Chatman, “Deconstructing Development Density,” 1008.

${ }^{15}$ Badoe and Miller, “Transportation Land-Use Interaction,” 235.
} 
comprehensive policies, plans, and principles for TOD. ${ }^{16}$ For example, Cervero found that many jurisdictions throughout the United States employed zoning overlays or combining districts in order to exclude auto-based uses and promote residential densities and floor area ratios that were favorable to TOD. ${ }^{17}$ Some frequently cited impediments to TOD implementation were the existing overwhelmingly auto-dependent land-use form of many cities, community opposition, and varying political agendas from the numerous stakeholders who could be involved in development. ${ }^{18}$ There are a variety of different ways to successfully implement TOD in order to meet local jurisdictions' diverse needs.

Levine and Inam and Boarnet and Compin explained that local governments generally favored expansion in transportation and land-use options, but different regulations at the local and regional levels played a large role in the speed and incremental approach with which TOD may be put into practice. ${ }^{19}$ While it is a promising sign that there is such a large and growing interest in TOD among governmental agencies, this can present problems when planning for funding and implementation. For example, Handy found that some Metropolitan Planning Organizations (MPOs) are having trouble keeping up with the rapidly changing technological aspects of the TOD planning process. ${ }^{20}$ This presents a potential financial stumbling block as MPOs may emphasize a single goal, while cities are trying to promote a wide variety of goals. Cervero agrees there is need for further study on the importance of vertical (federal, state, and local) versus horizontal (transit agency, municipality, and MPO) interaction in the implementation of TOD. ${ }^{21}$ Integrating various TOD program objectives into a cohesive regional policy will be a challenge for many MPOs.

While it is understandable that there are differences of opinion on the best methods to implement TOD plans and policies (varying local conditions require varying approaches) there is consensus on the best success indicators that could be a part of any city's evaluation program. For example, Renne and Wells listed the most widely accepted success indicators as:

1. Transit ridership - Increased transit ridership is often the primary goal of TOD.

\footnotetext{
${ }^{16}$ Jonathan Levine and Aseem Inam, “The Market for Transportation-Land Use Integration: Do Developers Want Smarter Growth than Regulations Allow?” Transportation 31 (November 2004): 409427; Cervero, “Transit-Oriented Development in the United States,” 1-534; Marlon Boarnet and Nicholas S. Compin, "Transit-Oriented Development in San Diego County: The Incremental Implementation of a Planning Idea,” Journal of the American Planning Association 65 (Winter 1999): 1-37; Robert Cervero, "Road Expansion, Urban Growth, and Induced Travel: A Path Analysis,” Journal of the American Planning Association 69 (Spring 2003): 145-163; Susan Handy, "Regional Transportation Planning in the US: An Examination of Changes in Technical Aspects of the Planning Process in Response to Changing Goals,” Transport Policy 15 (2008): 113-126.

${ }^{17}$ Cervero, “Transit-Oriented Development in the United States,” 454.

${ }^{18}$ Ibid., 109.

${ }^{19}$ Levine and Inam, “The Market for Transportation-Land Use Integration,” 409-427; Boarnet and Compin, "Transit-Oriented Development in San Diego County," 1-37.

${ }^{20}$ Handy, "Regional Transportation Planning in the US," 113-126.

${ }^{21}$ Cervero, “Road Expansion, Urban Growth, and Induced Travel,” 160.
} 
2. Density - Increased density is essential to increased transit ridership.

3. Quality of streetscape design - People spend more time in nice spaces.

4. Quantity of mixed-use structures - The more mixed-use structures, the further the area is in its transformation.

5. Pedestrian activity/safety - Streetscapes and infrastructure should be oriented to a pedestrian scale.

6. Increase in property value/tax revenue - As construction activity increases, the result, over time, can be an increase in tax revenue for local governmental agencies.

7. Public perception - Anti-growth sentiments can be strong, but successful redevelopment has the potential to significantly improve the value of an area and stimulate further growth.

8. Mode connections - The most efficient transit stations provide easy transferability between various modes.

9. Parking configuration - The proper amount of parking is essential to a successful TOD. ${ }^{22}$

While the above indicators are widely accepted as being the best indicators for evaluating TOD success, it is also important to choose indicators that make sense from a local perspective and that are consistent with the specific municipality's level of staffing and technological ability.

All but one of the articles agreed that TOD should be supported. Gordon and Richardson found that because in many areas a low-density, auto-based urban form is the overwhelming choice for residential living, there should not be support for compact cities. ${ }^{23}$ This conclusion seems to be based on backward thinking, and does not seem to acknowledge the growing acceptance of the unaccounted-for impacts and costs that the single-family, detached-housing form promotes. Finally, in the only article that dealt with TOD's legal basis, White and McDaniel found that while TOD represents a significant departure from traditional zoning regulations, at the conceptual level, "TOD has a sound legal and constitutional basis." ${ }^{24}$ This conclusion was reached based on the fact that many aspects of transit-oriented development have been litigated. In addition, many states have incorporated TOD principles into their zoning and planning codes and plans.

\footnotetext{
${ }^{22}$ John L. Renne and Jan S. Wells, “Transit-Oriented Development: Developing A Strategy to Measure Success,” National Cooperative Highway Research Program 294 (February 2005): 22.

${ }^{23}$ Peter Gordon and Harry W. Richardson, “Are Compact Cities a Desirable Planning Goal?” Journal of the American Planning Association 63 (Winter 1997): 95.

${ }^{24}$ Mark S. White and James B. McDaniel, “The Zoning and Real Estate Implications of TransitOriented Development,” Transit Cooperative Research Program 12 (January 1999): 39.
} 


\subsubsection{Does TOD increase land values?}

The determining factors on whether a TOD gets built are local market conditions and whether developers can make a return on their investment by building TOD. The primary goal of most for-profit developers is not lowering air pollution impacts, providing affordable housing, or trying to increase social diversity. Most developers are in the business of building structures and generating profit. TOD has the greatest potential for success if it can be implemented in a way that provides the greatest benefits for the largest group of stakeholders. While not all development is undertaken by forprofit developers, it is important to understand what drives this most significant market segment.

For this literature review, nine studies that evaluated the relationship between economics and the development of successful TOD were reviewed. The main topics that were found throughout the literature were land values, developers' perceptions, financial barriers, labor markets, and employment and job-to-housing balance. More specifically, six of the studies evaluated land-use mix, transit proximity, and developers' perceptions in relation to land values. They found a variety of different results. This mix of results showed that there were many different variables that could affect the desirability and value of land. It also showed that it was important for developers to evaluate local conditions, policies, and perceptions in order to implement TOD successfully. ${ }^{25}$ The significance of these variables is discussed in more detail in the following paragraphs.

Researchers found that a mix of land uses positively impacted residential land values, which resulted in mixed-use development near transit stops having higher prices and generally outperforming others in the market. ${ }^{26}$ The reason for the higher prices was because the land around urban rail stations was highly accessible. ${ }^{27}$ Given these results, it is no surprise that there was not as strong an influence at terminal stations. Finally, there was agreement that building housing and mixing land uses benefited local governments' financial standing. This is a result of higher property tax proceeds, which are based on higher assessed values of the residential property and greater sales tax proceeds.

Cervero, Badoe and Miller, and Gordon and Richardson found opposite or mixed results than the previous studies', which found that mixed-use development near transit stops had higher prices. For example, they asserted that for every study that shows being

\footnotetext{
${ }^{25}$ Robert Cervero and Michael Duncan, “Neighborhood Composition and Residential Land Prices: Does Exclusion Raise or Lower Values?” Urban Studies 41 (February 2004): 299-315; Cervero, "Road Expansion, Urban Growth, and Induced Travel,” 145-163; Badoe and Miller, "Transportation Land-Use Interaction,” 235-263; Robert Cervero, “Jobs-Housing Balance Revisited,” Journal of the American Planning Association 62 (Autumn 1996): 492-511; Gordon and Richardson, “Are Compact Cities a Desirable Planning Goal?” 95-107; Cervero, “Transit-Oriented Development in the United States,” 1-534.

${ }^{26}$ Cervero and Duncan, “Neighborhood Composition and Residential Land Prices,” 299-315; Cervero, “Jobs-Housing Balance Revisited,” 492-511; Cervero, “Transit-Oriented Development in the United States,” 1-534.

${ }^{27}$ Cervero, “Jobs-Housing Balance Revisited,” 499.
} 
near transit raises property values, there is another study that shows it does not. ${ }^{28}$ The differences could be based on the fact that there are different benefits that accrue to different mixes of land uses and in different locales. Also, there is incomplete knowledge on how the proximity of various modes of transit affects property values. Gordon and Richardson added that analysis of employment data indicated a continuation of the decentralization of most activities, and concluded that "downtown renewal efforts had failed." ${ }^{29}$ While there are many variables that can lead to differences in findings between the studies on property values, the overall economic case for promoting TOD is valid and well established.

Three studies evaluated economic performance as well as labor markets and employment. ${ }^{30}$ Overall, the studies showed that metropolitan areas, with good accessibility between jobs and housing, enjoyed economic benefits and higher productivity levels. However, Cervero concluded that job surplus cities may be "more of a planning failure than a market failure."31 This is because many affluent cities with surplus jobs restrict housing growth either for financial or exclusionary reasons. Without state encouragement, many communities are unwilling to allow new housing, especially lower-income units, where they are most needed. ${ }^{32}$

This intentional exclusion of low-income units is unfortunate because one of the best ways to reduce vehicle miles traveled (VMT) is to add more housing in or near jobrich cities. It is also important when planning for new housing to make sure that the housing product is tailored to the income level and taste of the targeted workers. Arrington and Cervero found "access to high-quality transit is becoming increasingly important to firms trying to attract creative class workers in the knowledge economy."33 An additional financial reason that was cited to move toward a more mixed-use, transitbased development pattern included the finding that some places with sprawling, autobased patterns were poor economic performers. Regionally, inadequate housing was identified as eventually leading to economic decline, making regional transportation and environmental problems worse. Overall, most studies indicated that TOD generally improves land values and holds promise for economic development. Unfortunately, some of the important social benefits of TOD, such as the opportunity to provide affordable housing, are not accounted for in economic evaluations of the benefits of TOD.

\footnotetext{
${ }^{28}$ Cervero, “Road Expansion, Urban Growth, and Induced Travel,” 145-163; Badoe and Miller, “Transportation Land-Use Interaction,” 235-263; Gordon and Richardson, “Are Compact Cities a Desirable Planning Goal?” 95-107.

${ }^{29}$ Gordon and Richardson, “Are Compact Cities a Desirable Planning Goal?” 100.

${ }^{30}$ Cervero, “Jobs-Housing Balance Revisited,” 492-511; Robert Cervero, "Efficient Urbanization: Economic Performance and the Shape of the Metropolis,” Urban Studies 38 (2001): 1651-1671; Arrington and Cervero, "Effects of TOD on Housing, Parking, and Travel," 1-67.

${ }^{31}$ Cervero, “Jobs-Housing Balance Revisited,” 507.

${ }^{32}$ Ibid.

${ }^{33}$ Arrington and Cervero, "Effects of TOD on Housing, Parking, and Travel," 1.
} 


\subsubsection{Does TOD decrease environmental impacts?}

The basic justification for pursuing TOD is the underlying concept that compact, mixed-use, development centered around transit stations leads to a decrease in environmental impacts. This is when compared to sprawling auto-based development, which has been the predominant neighborhood form since at least the post-World War II period. In this section, seven studies are reviewed that evaluated the ways in which TOD and the environment are related. The main topics discussed were air pollution and greenhouse gas emissions (mainly in terms of VMT), as well as the energy use and sustainability advantages of a more compact development pattern.

There is shared consensus that TOD results in a more sustainable built form, with lessening of specific environmental impacts, when compared to other more sprawling development forms. ${ }^{34}$ Gordon and Richardson supplied the lone dissenting view. ${ }^{35}$ The most direct environmental benefit of TOD is a reduction in carbon emissions and air pollution, brought about by a reduction in VMT and vehicle hours traveled (VHT). Salon et al., Handy, and Stone et al. all studied land-use and zoning regulations at the local level and found that local governments can have a large effect on carbon emissions and air pollution. ${ }^{36}$ The greatest gains can be made by enacting policies that allow for higher densities, a mix of uses, and consequently more alternatives to driving. These policies allow people to drive less because they are brought closer to their destinations and they have better access to other modes. Stone et al. also added that residential density in urban areas is more than twice as effective in reducing vehicle travel and emissions than in suburban areas. ${ }^{37}$ This shows that policies and regulations that enable TOD can reach their greatest potential in urban areas. While the authors are correct on the environmental benefits of TOD, the magnitude of the predominating suburban development pattern is discouraging.

Land use and planning are the most viable means of achieving large emissions reductions, which means it is up to local governments to act. Stone et al. explained that the U.S. Environmental Protection Agency (EPA) is prohibited from regulating land use at the local and regional levels by the Clean Air Act. This has resulted in an end-of-pipe

\footnotetext{
${ }^{34}$ Deborah Salon et al., "City Carbon Budgets: A Proposal to Align Incentives for ClimateFriendly Communities,” Energy Policy 38 (2010): 2032-2041; Susan Handy, “Smart Growth and the Transportation Land-Use Connection: What Does the Research Tell Us?” International Regional Science Review 28 (April 2005): 146-167; Brian Stone Jr., et al., “Is Compact Growth Good for Air Quality?” Journal of the American Planning Association 73 (2007) 404-418; William B. Shore, "Land-Use, Transportation and Sustainability,” Technology in Society 28 (2006): 27-43; Chia-Nung Li and Tsung-Yu Lai, "Why Should Cities Change from DOT to TOD?” Institution of Civil Engineers 162 (May 2009): 7178; Jose A. Gomez-Ibanez et al., "Driving and the Built Environment: The Effects of Compact Development on Motorized Travel, Energy Use, and CO2 Emissions,” National Research Council 298 (2009): 1-240.

${ }^{35}$ Gordon and Richardson, “Are Compact Cities a Desirable Planning Goal?” 95.

${ }^{36}$ Salon et al., "City Carbon Budgets,” 2032-2041; Handy, "Smart Growth and the TransportationLand Use Connection: What Does the Research Tell Us?” 146-167; Stone et al., "Is Compact Growth Good for Air Quality?” 404-418.

${ }^{37}$ Stone et al., "Is Compact Growth Good for Air Quality?” 404.
} 
approach at the city and regional level that has not been particularly successful. ${ }^{38}$ In addition to air pollution and carbon emissions, there are other environmental and sustainability issues that may be more efficiently addressed with a more coordinated regional approach. Energy distribution and use, water use, food production, and waste generation and disposal are all adversely affected by a decentralized and sprawling development pattern. Shore concludes by emphasizing that while the U.S. has begun to recentralize, additional legislation and plans are needed at the regional level. ${ }^{39}$ The studies indicate that a top-down approach, with more guidance at the regional, state, and federal levels, holds the greatest promise for effecting significant change.

While land use and planning in the U.S. are usually handled at the local and regional levels, it is important to note that many environmental contaminants, such as air pollution, do not respect city, state, or even national boundaries and can adversely affect people worldwide. It is important for all people to acknowledge this fact and work toward the common good. In the only study from abroad (Taipei City, China) Li and Lai agreed with the findings of many of the studies conducted domestically; there is a relationship between sustainable development and the concepts of TOD. ${ }^{40}$ The studies were lacking in their description of the magnitude of the positive impacts. Gomez et al. agreed with the other authors that TOD has a greater potential to reduce VMT, energy use, and carbon emissions, but added that, to what degree, is in many cases unclear. ${ }^{41}$

Taking it a step further, Gordon and Richardson found that because energy is a scarce resource, markets should be allowed to guide it, and government intervention is the real source of the problem. ${ }^{42}$ Most would agree that energy is a scarce resource; but, the fact of the matter is the energy markets do not currently account for many of the externalities associated with energy production and use, and until they do so, the markets will need government intervention in order to benefit the public good. Overall, the body of knowledge on TOD and the environment indicates that it does result in a decrease in environmental impacts.

\subsubsection{Does TOD have lower trip generation rates?}

At the most basic level, TOD is intended to result in development that supports the use of public transportation. TOD should impact travel behavior by providing more opportunities to use alternative transportation modes. Transit is an integral part of TOD, and there have been many studies that look at the transit and transportation issues surrounding TOD. The clearest message that has come out of these studies is that TOD can be an effective tool to support the use of public transportation and provide environmental and societal benefits.

\footnotetext{
${ }^{38}$ Ibid.

${ }^{39}$ Shore, “Land-Use, Transportation and Sustainability,” 27.

${ }^{40} \mathrm{Li}$ and Lai, "Why Should Cities Change from DOT to TOD?" 76.

${ }^{41}$ Gomez-Ibanez et al., "Driving and the Built Environment,” 184.

${ }^{42}$ Gordon and Richardson, “Are Compact Cities a Desirable Planning Goal?” 97.
} 
Twelve studies evaluated travel behavior and the development of successful TOD, including: job to housing balance, commuting behavior, transit ridership, mode share, parking requirements, and the public perception of transit. Some of the biggest benefits from TOD were reductions in VMT and VHT by cities that had achieved a job-tohousing balance. Cervero and Duncan attributed this to linking jobs and housing with transit, thereby enabling retail and service trips to be combined with work trips. This study showed that achieving a job to housing balance and mixed-use TOD, are complementary land-use strategies. ${ }^{43}$

Five of the studies - Cervero and Gotham, Southworth, Khattak and Rodriguez, Gomez et al., and Weinstein et al._-agreed that neighborhood layout does have an effect on commuting behavior. Furthermore, transit-based, mixed-use neighborhoods had lower automobile trip generation and VMT rates, and higher walking and biking shares than automobile-based neighborhoods. Transit neighborhoods also had higher densities, which suggests that residents were substituting walking and biking for auto trips. ${ }^{44}$ The walking and biking mode shares increased because destinations became closer, which resulted in shorter trip lengths, and made it easier for people to get around. In addition, the studies agreed that pedestrians are typically willing to walk about half a mile to a station. While the half-mile walking range is often cited, planners should pay particular attention to the local community's perception of walking and adjust plans accordingly. In some cases, pedestrians may be willing to walk further or shorter distances, based on variables such as streetscape, topography, and local climate.

TOD can have a variety of effects on transit ridership, car ownership, and people's perception of transit. For example, Arrington and Cervero, Lund, Rhindress et al., and Karash et al. found that a top reason households said they moved to TOD was because of better access to transit; as a result, transit ridership for work trips increased in TOD areas. Also, current transit use was the greatest indicator of continued support. ${ }^{45} \mathrm{It}$ is clear from the studies that people who choose to live in TOD use transit at a much higher rate and own significantly fewer cars than those who do not. It is therefore important for local governments to establish parking requirements that are flexible

\footnotetext{
${ }^{43}$ Robert Cervero and Michael Duncan, "Which Reduces Vehicle Travel More: Jobs-Housing Balance or Retail-Housing Mixing?” Journal of the American Planning Association 72 (Autumn 2006): 488.

${ }^{44}$ Robert Cervero, and Roger Gorham, "Commuting in Transit Versus Automobile Neighborhoods,” Journal of the American Planning Association 61 (Spring 1995): 210-226; Frank Southworth, "On the Potential Impacts of Land Use Change Policies on Automobile Vehicle Miles of Travel,” Energy Policy 29 (2001): 1271-1283; Asad J. Khattak and Daniel Rodriguez, “Travel Behavior in Neo-Traditional Neighborhood Developments: A Case Study in USA,” Transportation Research A 39 (2005): 481-500; Gomez-Ibanez et al., "Driving and the Built Environment,”1-240; Asha WeinsteinAgrawal, Marc Schlossberg, and Katja Irvin, "How Far, by Which Route and Why? A Spatial Analysis of Pedestrian Preference,” Journal of Urban Design 13 (February 2008): 81-98.

${ }^{45}$ Arrington and Cervero, "Effects of TOD on Housing, Parking, and Travel," 1-67; Hollie Lund, "Reasons for Living in a Transit-Oriented Development, and Associated Transit Use," Journal of the American Planning Association 72 (Summer 2006): 1-144; Mindy Rhindress et al., "Understanding How to Motivate Communities to Support and Ride Public Transportation,” Transit Cooperative Research Program 122 (2008): 1-92; Karash et al., "Understanding How Individuals Make Travel and Location Decisions," 1-147.
} 
enough to allow for reductions in parking requirements to adequately achieve the cost savings associated with less parking.

Davis et al. found that public perception often forces cities to require more parking than is usually needed. ${ }^{46}$ This translates to additional costs to developers, which is then passed on to owners and renters and leads to an undermining of the entire concept of TOD. Handy points out that new transportation infrastructure spending on transit systems has the potential to influence where growth occurs, much as it does with new highway capacity. ${ }^{47}$ This is another reason it is important for cities and regions to clearly identify their goals and locations for future long-term growth. Overall, the body of knowledge on TOD and travel behavior indicates that TOD does result in lower automobile trip generation rates. It is important to take a long-term comprehensive approach to funding transportation infrastructure improvements and to make sure that future infrastructure, such as roads and rail lines, will work cohesively toward the common goal of enhanced mobility.

\subsubsection{Does TOD increase affordable housing opportunities?}

The most controversial aspect of TOD is the social diversity, equity, and affordable housing topics. In many communities, neighborhood opposition to TOD is directly related to the perception that higher-density housing and affordable housing will result in lower property values for existing residents. In addition, many neighbors also oppose TOD because they believe that diversity will come with affordable housing, which to some is perceived negatively.

Eight studies evaluated, and generally agreed, that social issues, including affordable housing, diversity, demographics, and the social equity of TOD residents, are important to understand when formulating and implementing TOD policies. More specifically, Bhat and Guo, White and McDaniel, and Arrington and Cervero found that TOD presented the opportunity to produce affordable housing. ${ }^{48}$ Bhat and Guo found that low-income households owned fewer cars and were constrained to live in areas that necessitated longer commutes or had higher employment density. ${ }^{49}$ White and McDaniel agreed with these findings and further concluded that TOD is a promising way to meet public need while increasing transit ridership, producing affordable housing opportunities and other development opportunities along transit corridors and station areas. ${ }^{50}$ TOD has

\footnotetext{
${ }^{46}$ Amelie Y. Davis et al., "The Environmental and Economic Costs of Sprawling Parking Lots in the United States,” Land Use Policy 27 (2010): 260.

${ }^{47}$ Handy, "Smart Growth and the Transportation-Land Use Connection,” 157.

${ }^{48}$ Chandra R. Bhat and Jessica Y. Guo, “A Comprehensive Analysis of Built Environment Characteristics on Household Residential Choice and Auto Ownership Levels,” Transportation Research B 41 (2007): 506-526; White and McDaniel, “The Zoning and Real Estate Implications of Transit-Oriented Development,” 1-51; Arrington and Cervero, “Effects of TOD on Housing, Parking, and Travel,” 1-67.

${ }^{49}$ Bhat and Guo, "A Comprehensive Analysis of Built Environment Characteristics on Household Residential Choice and Auto Ownership Levels,” 521.

${ }^{50}$ White and McDaniel, "The Zoning and Real Estate Implications of Transit-Oriented Development," 40.
} 
a great potential to meet affordable housing needs, but special attention must be paid to parking requirements and the effect they have on prices. For example, some TOD does not achieve its affordability potential because of the added costs of development, based on incorrect assumptions about traffic generation and required parking spaces.

Scholars examining demographics of TOD residents found a pattern of childless individuals or couples, who were usually younger professionals or older empty nesters. In addition, they found a wide age spectrum, but affordability was often the top consideration in deciding to locate in TOD. ${ }^{51}$ With TOD will come new challenges to address in terms of diversity and cultural acceptance. Blanco et al. acknowledged the point that embracing diversity in urban places requires tolerance of both diversity itself and conflict. Also, community as defined by common race, ethnicity, social class, and age may need to be redefined to be based more on the occupation of common space. ${ }^{52}$ This change in the definition or perception of community is very pertinent and important when planning for redevelopment generally.

Finally, Winston and Maheshri and Lin Gau looked at issues of social equity in TOD. Part of the rationale for providing public funding for transit is that it provides a socially desirable outcome and adds to social equity. ${ }^{53}$ However, while rail expansion generally receives strong political support, it is important for planners and policymakers to carefully evaluate the costs and benefits of transit projects to ensure they provide the desired outcomes and they are socially equitable. Similarly, in a study from the Chunghsiao-Fuhsing station area in Taipei, China, Lin and Gau found that allowing increased floor area ratios for various land uses can boost subway ridership; it is important to balance the reduced social equity costs and impacts to the living environment. ${ }^{54}$ In other words, there may be a limit to the intensity of land use of an area before it may become inhospitable for human habitation. Overall, the body of knowledge on TOD, social diversity, and equity did have some clear findings. For example, TOD does result in increased opportunities for affordable housing.

\subsection{Conclusion}

Transit-oriented development holds great promise for being a tool which can be successfully employed to bring about changes to the built environment. While it is clear

\footnotetext{
${ }^{51}$ Arrington and Cervero, "Effects of TOD on Housing, Parking, and Travel," 1-67; Badoe and Miller, “Transportation Land-Use Interaction,” 235-263; Hilda Blanco et al., “Hot, Congested, Crowded and Diverse: Emerging Research Agendas in Planning,” Progress in Planning 71 (2009): 153-205; GomezIbanez et al., "Driving and the Built Environment," 1-240.

${ }^{52}$ Blanco et al., "Hot, Congested, Crowded and Diverse,” 195.

${ }^{53}$ Clifford Winston and Vikram Maheshri, "On the Social Desirability of Urban Rail Transit Systems,” Journal of Urban Economics 62 (2007): 362-382; J.J. Lin and C.C. Gau, “A TOD Planning Model to Review the Regulation of Allowable Development Densities around Subway Station," Land Use Policy 23 (2006): 353-360.

${ }^{54}$ Lin and Gau, “A TOD Planning Model to Review the Regulation of Allowable Development Densities around Subway Station,” 353.
} 
that certain aspects of TOD, such as increased density and decreased environmental impacts, provide quantifiable benefits, there are other aspects that are more difficult to interpret. For example, with increased density there often comes community opposition from existing neighbors. Each municipality must balance the need for affordable housing with good transit access, with neighborhood opposition, to determine what the appropriate level is for their specific community. Also, there does not appear to be a clear answer for the question of TOD and land values; most of the time, TOD results in an increase in land values, but this is not always the case.

While TOD certainly results in lower automobile trip generation rates, VMT, and emissions, there are still reasons that TOD may not be the best solution in all cases. For example, many low-density or remote areas do not readily lend themselves to this development form. Also, some communities are based specifically on opposite ideals from TOD. For example, low-density, single-family house communities planned around the automobile may want to preserve that form specifically because it keeps prices relatively high and the demographics of the population relatively homogenous. When dealing with development and people, it is hard to reach a conclusion that fits every circumstance, every time. Perhaps the most important lesson we can learn from the existing research on TOD is that more often than not, the best way to proceed is to look to past experiences as a starting point and try to tailor a specific solution for the particular community's needs. 


\section{CHAPTER 3: CURRENT STATUS OF STATE AND REGIONAL AGENCY'S TOD POLICIES AND PROGRAMS}

\subsection{Introduction}

There are several state and regional agencies that set policies and programs which are applicable to how Palo Alto plans for growth. These agencies and their policies and programs affect how Palo Alto plans for growth within its boundaries as well as other jurisdictions across the region and state. Some policies and programs are directly related to TOD. Others take a more indirect approach by addressing air quality concerns or development in general. The five agencies whose policies and programs will be reviewed in this chapter include: the California Air Resources Board, the Metropolitan Transportation Commission, the Association of Bay Area Governments, the Bay Area Air Quality Management District, and the California Department of Transportation. There is also a section on transit operators who are currently operating in Palo Alto. It is important to understand these agencies' TOD policies and programs to ensure that Palo Alto is in compliance with any requirements and to make sure Palo Alto's PTOD regulations are comprehensive.

\subsection{California Air Resources Board (CARB)}

The California Air Resources Board (CARB) is a state-level agency that was established with the responsibility of protecting the public health and safety of people who live within its jurisdiction in relation to air quality issues. This is accomplished with an understanding of the environmental and economic realities of the state. ${ }^{55}$ The CARB's aims to provide safe and clean air to Californians while reducing greenhouse gases (GHG). ${ }^{56}$

As the lead state agency dealing with air quality, the CARB works through regional air districts such as the Bay Area Air Quality Management District (BAAQMD) to develop and implement air quality policies and programs. The goal of these programs is to ensure that air quality in the state is in compliance with the state and federal Clean Air Acts. It has become increasingly apparent that these programs are most successful through multi-jurisdictional cooperation, especially when developing GHG reduction strategies. $^{57}$

To ensure that California's air quality is in compliance with the state and federal Clean Air Acts, two bills were recently enacted that directly address GHG emissions

\footnotetext{
${ }^{55}$ Air Resources Board, “ARB Mission and Goals,” Air Resources Board, http://www.arb.ca.gov/html/mission.htm (accessed May 13, 2010).

${ }^{56}$ Air Resources Board, "Introduction to the Air Resources Board,” Air Resources Board, http://www.arb.ca.gov/html/brochure/arb.htm (accessed May 13, 2010).

${ }^{57}$ Air Resources Board, “Air Quality and Transportation Planning,” Air Resources Board, http://www.arb.ca.gov/planning/planning.htm (accessed May 13, 2010).
} 
reduction in the state. The first, Assembly Bill 32, sets targets for statewide GHG emissions reduction. The second, Senate Bill 375, provides a framework for how local jurisdictions can meet the reduction targets. As a result of these laws, local and regional jurisdictions are planning strategies to reach the GHG emissions reduction targets set by the CARB.

\section{Assembly Bill 32 (AB 32)}

Assembly Bill 32 (AB 32), California Global Warming Solutions Act of 2006, is a bill sponsored by State Assemblyman Fabian Nuñez that was signed into law in 2006. The law requires the reduction of state GHG emissions to 1990 levels by the year 2020 . AB 32 also gives the CARB authority to regulate sources of GHG emissions that contribute to climate change. According to the CARB, transportation accounts for 40 percent of state GHG emissions. To meet the GHG reduction targets under AB 32, emissions will need to be reduced by 30 percent from 2020 projections or about 15 percent from current levels. ${ }^{58}$ Therefore, to meet the emissions reduction targets required by $\mathrm{AB} 32$, emissions from the transportation sector must be addressed.

As the lead agency the CARB is responsible for setting up the regulatory framework to ensure the requirements of $\mathrm{AB} 32$, including reporting and verification of state GHG emissions are met. ${ }^{59}$ While the transportation sector accounts for the largest source of greenhouse gas (GHG) emissions in the state, virtually every industry that participates in the State's economy will play a role in meeting the reduction goals. Since AB 32's enactment, the CARB has begun to implement policies to reduce GHG emissions. In addition, the CARB has developed and adopted a scoping plan that will contain the main strategies for reducing GHG emission. ${ }^{60}$

\section{Senate Bill 375 (SB 375)}

Senate Bill 375 (SB 375), Linking Regional Transportation Plans to State Greenhouse Gas Reduction Goals, is a bill authored by State Senator Darrell Steinberg that was signed into law in 2008. The law requires local governments in California to meet GHG emissions reduction targets by revising planning policies and zoning regulations in order to minimize driving and maximize the use of alternative travel modes. The responsibility for achieving the targets has been placed upon the 18 regional MPOs in California.

In preparation for meeting the targets, each MPO will develop an integrated regional transportation, land-use, and housing plan known as a Sustainable Communities

\footnotetext{
${ }^{58}$ Air Resources Board, “Climate Change Program,” Air Resources Board, http://www.arb.ca.gov/cc/cc.htm (accessed May 13, 2010).

${ }^{59}$ Wikipedia, “Global Warming Solutions Act of 2006,” Wikipedia, http://en.wikipedia.org/wiki/Global_Warming_Solutions_Act_of_2006 (accessed May 13, 2010). ${ }^{60}$ Ibid.
} 
Strategy (SCS). ${ }^{61}$ The ultimate intent of the SCS is to reduce GHG emissions from the transportation sector while improving the quality of life of California's communities. In the Bay Area, the lead agency is the MTC, acting as the regional MPO, and the Association of Bay Area Governments (ABAG).

SB 375 achieves its goals by aligning the Regional Housing Needs Assessment (RHNA) and Regional Transportation Plan (RTP) with local land-use planning documents, such as the general plan housing element and zoning ordinance, in order to reduce GHG emissions from motor vehicle trips. The CARB has been charged with working with local and regional agencies to set targets for reducing GHGs for each of the MPOs in the state. ${ }^{62}$

\subsection{Metropolitan Transportation Commission (MTC)}

The Metropolitan Transportation Commission (MTC) was created as the San Francisco Bay Area's Metropolitan Planning Organization (MPO). An MPO is a federally designated planning, financing, and coordinating agency responsible for transportation planning and funding in its region. The MTC also functions as the Bay Area's Regional Transportation Planning Agency (RTPA), a state designation. The MTC is responsible for the nine counties, 101 cities, and 7 million people who reside in the region's 7,000 square miles. ${ }^{63}$

Based on the requirements of SB 375, the RTP prepared by each MPO must incorporate a Sustainable Communities Strategy (SCS), which is a regional growth plan that addresses transportation investment and GHG emissions reduction in the region. More specifically, the Bay Area's SCS must define the most efficient and equitable plan for accommodating the Bay Area's population increases across all income groups over the next 25 years. ${ }^{64}$ The anticipated outcome of this effort is a significant reduction in GHG emissions from the car and light truck sector. The SCS will designate proposed locations of uses, residential densities (dwelling units / acre), and building intensities (floor area ratios) for specific areas and the region as a whole. ${ }^{65}$

The Focus initiative is a current planning effort by the Bay Area's four regional planning agencies (MTC, ABAG, BAAQMD, and Bay Conservation and Development Commission [BCDC]). The goal of the effort is to plan for a sustainable future for the current and future residents of the Bay Area. The main component of the Focus initiative is the 120 Priority Development Areas (PDAs) located within 60 Bay Area jurisdictions.

\footnotetext{
${ }^{61}$ Air Resources Board, “Senate Bill 375 - Regional Targets,” Air Resources Board, http://www.arb.ca.gov/cc/sb375/sb375.htm (accessed May 13, 2010).

${ }^{62}$ Ibid.

${ }^{63}$ Metropolitan Transportation Commission, “About MTC,” Metropolitan Transportation Commission, http://www.mtc.ca.gov/about_mtc/about.htm (accessed May 13, 2010).

${ }^{64}$ Joseph P. Bort, "Fact Sheet," Metropolitan Transportation Commission, http://www.mtc.ca.gov/legislation/SB375_Fact_Sheet.pdf (accessed May 13, 2010).

${ }^{65}$ One Bay Area, "Background,” One Bay Area, http://www.onebayarea.org/background.htm (accessed May 13, 2010).
} 
The PDAs were designated as being near public transit and suitable for infill development. The Focus initiative seeks to validate the idea that new development should be near existing and planned transit resources to most effectively reduce GHG emissions. $^{66}$

While the PDAs cover only approximately three percent of the region's land area, they are being planned to accommodate approximately 50 percent of the region's projected population increase through $2035 .{ }^{67}$ Cities and counties are in the process of amending their local governing documents to ensure they are planning for their share of the growth. By designating a PDA in their community, local jurisdictions have made a commitment to support the effort by focusing housing, retail, and other infrastructure in these areas. The City of Palo Alto's California Avenue PTOD Combining District area is identified as one of the PDAs. In addition, the City of Palo Alto recently received several grants from the MTC for projects in the area including an update to the city's Bicycle Transportation Plan, Park Boulevard Bicycle Boulevard improvements, bike rack installations, enhanced crosswalks, and bicycle route directional signage. The Focus initiative and other grant and incentive programs provide much-needed funding to local jurisdictions to begin implementing the SCS of the RTP.

\subsection{Association of Bay Area Governments (ABAG)}

The Association of Bay Area Governments (ABAG) was formed as the state's first Council of Governments (COG).The ABAG is responsible for coordinating and addressing regional issues that affect the nine counties, 101 cities, and seven million people who live in the Bay Area. ${ }^{68}$ ABAG's mission statement is, ABAG is committed to enhancing the quality of life in the San Francisco Bay Area by leading the region in advocacy, collaboration, and excellence, in planning, research, and member service. ${ }^{69}$ The most pressing issues that ABAG and the Bay Area face can be summed up in the following areas: housing issues, transportation issues, social equity issues, and environmental issues.

The availability of affordable housing is one of the biggest issues in the Bay Area. Imbalances in jobs and housing result in longer and more congested commutes. Housing and transportation issues disproportionately affect the lowest-paid members of the region. All of these challenges are directly tied into the region's natural systems and environment. Due to the regional nature of these issues, it is important to address them from a regional perspective. ${ }^{70}$ Another role that ABAG holds is the determination of each city and county's fair share of the region's projected future housing needs. Local

\footnotetext{
${ }^{66}$ Ibid.

${ }^{67}$ Ibid.

${ }^{68}$ Association of Bay Area Governments, “ABAG History,” Association of Bay Area Governments, http://www.abag.ca.gov/overview/history.html (accessed May 13, 2010).

${ }^{69}$ Association of Bay Area Governments, “ABAG Overview,” Association of Bay Area Governments, http://www.abag.ca.gov/overview (accessed May 13, 2010).

${ }^{70}$ Association of Bay Area Governments, "Bay area Challenges," Association of Bay Area Governments, http://www.abag.ca.gov/overview/challenges.html (accessed May 13, 2010).
} 
governments must then plan to accommodate the projected need by amending their housing elements within their general plan.

The Regional Housing Needs Assessment (RHNA) is a forecast of future population growth prepared by the ABAG for each of its constituent members in the Bay Area region. The California Department of Housing and Community Development (HCD) provides population projections to each region. The purpose of the RHNA is to equitably allocate housing units for all income levels across each county and city in the region. To ensure compliance, local governmental organizations must update the housing elements of their general plans. ${ }^{71}$ In this RHNA cycle, Palo Alto has been allocated 2,860 units. Under the new rules brought about by the enactment of SB 375, Palo Alto will update its housing element every eight years as opposed to the previous requirement of five years. Another anticipated outcome of SB 375 is the schedule for the RTP, the RHNA, and the housing element update will be coordinated on an eight-year schedule. ${ }^{72}$

\subsection{Bay Area Air Quality Management District (BAAQMD)}

The Bay Area Air Quality Management District (BAAQMD) was created with the responsibility of addressing stationary sources of air pollution in the Bay Area region. The nine counties of the San Francisco Bay Area make up a regional air basin, which must address similar air pollution issues. Since air pollution does not respect jurisdictional boundaries, it is important for the nine counties and local cities to act in a coordinated manner. ${ }^{73}$ The BAAQMD aims to protect and improve air quality for Bay Area residents, while also being conscious of the global climate. ${ }^{74}$ Air quality truly is a regional or even global issue.

The BAAQMD has acknowledged and endorsed the principles of smart growth, as well as TOD, and plays an important role in ensuring their adoption by local jurisdictions. Two ways it accomplishes this include through the analysis of the potential air quality impact of cities' and counties' general plans, as well as review of significant development projects. It identifies potential problems and provides comments about the potential significant impacts. The BAAQMD supports the project alternatives and landuse and transportation decisions that will least impact air quality and that reduce motor vehicle use. ${ }^{75}$ Because of this fact, the BAAQMD has partnered with other regional and local government agencies to promote TOD and other forms of smart growth. The

\footnotetext{
${ }^{71}$ Association of Bay Area Governments, "Latest News,” Association of Bay Area Governments, http://www.abag.ca.gov/planning/housingneeds/ (accessed May 13, 2010).

${ }^{72}$ Ibid.

${ }^{73}$ Bay Area Air Quality Management District, “The Air District,” Bay Area Air Quality Management District, http://www.baaqmd.gov/The-Air-District.aspx (accessed May 13, 2010).

${ }^{74}$ Ibid.

${ }^{75}$ Bay Area Air Quality Management District, “Planning, Rules and Research Division,” Bay Area Air Quality Management District, http://www.baaqmd.gov/Divisions/Planning-and-Research.aspx (accessed May 13, 2010).
} 
BAAQMD acknowledges TOD's potential to provide housing, jobs, and retail and commercial services within a walkable community with excellent access to transit. ${ }^{76}$

\subsection{Palo Alto Transit Operators}

Palo Alto's California Avenue Caltrain station is a multimodal transit station that is currently served by Caltrain, Valley Transportation Authority (VTA) bus service, Dumbarton Express bus service, and several local shuttles. In 2006, the City of Palo Alto enacted the California Avenue PTOD Combining District regulations. This combining district allows greater flexibility in the development standards for new buildings in the vicinity of the station. In addition, there are context-based design criteria that ensure that new development is responsive to its context and compatible with adjacent development.

By enacting these regulations, the City of Palo Alto has taken a step toward becoming more compact and transit-oriented, with a resulting decrease in GHG emissions and a greater variety of mobility options. In addition, this added flexibility provides an incentive for Caltrain to redevelop the station area under a joint development agreement. The development would promote transit use by allowing residents and employees easy access to transit, generate additional revenue for Caltrain, and enhance the overall station area environment.

\section{Valley Transportation Authority (VTA)}

The Santa Clara Valley Transportation Authority (VTA) was created to manage the county's transportation system. VTA's main objective is the construction, operation, and maintenance of the county's bus and light-rail systems. One of the strategic goals contained in VTA's long-range planning document is to integrate transportation and land-use planning. ${ }^{77}$ To accomplish this goal, VTA established a TOD program.

The program promotes many of the components of TOD such as intensification and mix of land uses while providing for greater pedestrian accessibility at appropriate locations. However, land-use authority remains under the jurisdiction of local and county governmental agencies. Therefore, VTA works collaboratively with local jurisdictions to successfully implement TOD projects. In support of this program, cities are increasingly amending their zoning codes and regulations to include TOD districts at existing and future transit stations. ${ }^{78}$

\footnotetext{
${ }^{76}$ Bay Area Air Quality Management District, “Smart Growth,” Bay Area Air Quality Management District, http://www.baaqmd.gov/Divisions/Planning-and-Research/Smart-Growth.aspx (accessed May 13, 2010).

${ }^{77}$ VTA, “Transit-oriented Development (TOD) Program,” Santa Clara Valley Transportation Authority, http://www.vta.org/projects/tod.html (accessed May 13, 2010).

${ }^{78}$ Ibid.
} 
One of VTA's programs that aims to promote transit and pedestrian-oriented projects is the Community Design and Transportation (CDT) program. The program consists of grants to assist cities and the County of Santa Clara to include transit and pedestrian-oriented elements in infrastructure projects related to transit facilities, streets, and downtown areas. ${ }^{79}$ In April of 2010, the City of Palo Alto submitted an application to the CDT program for a variety of streetscape improvements including new streetlights, landscaped medians, wider sidewalks with bulb-outs, benches, restaurant tables and chairs, bike racks, kiosks, and improvements to the plaza near the Caltrain station. The project also includes a proposed reduction from four travel lanes to two to allow for sidewalk extensions and to slow traffic on the street. Up to 17 additional on-street parking spaces will be provided with the project.

${ }^{79}$ VTA, “Memorandum," Santa Clara Valley Transportation Authority, http://www.vta.org/projects/CDT_Capital_Application.pdf (accessed May 13, 2010). 


\section{CHAPTER 4: PALO ALTO HISTORY}

\subsection{Introduction}

Some of the information in this chapter was compiled during an in-person interview with the City of Palo Alto and Palo Alto Historical Association's Historian, Steve Staiger. As the City Historian, Steve is recognized as a leading authority on Palo Alto's history. This interview was conducted on August 12, 2010 at the City of Palo Alto’s Main Library.

Human habitation in the area that is now known as Palo Alto has a long and colorful history. For the purposes of this research report, the focus will begin with the town of Mayfield, then discuss Leland Stanford's influence, the creation of the City of Palo Alto, a review of early transportation in the city and surrounding region, and conclude with the city's early growth and industry. It is important to understand the history of Palo Alto to be able to formulate policies and programs that respect its deep roots, while also allowing growth in an almost completely built-out city.

\subsection{Mayfield}

The original human inhabitants of the area were the Ohlone people. Next was the era of Spanish exploration and settlement, which eventually brought an end to the Ohlones' way of life. After Mexico gained its independence from Spain, the rancho period - categorized by vast cattle herds - took place. Soon settlers arrived from throughout America and the rest of the world and California quickly became a state. ${ }^{80}$

Mayfield and Palo Alto were founded as two separate and distinct towns. Mayfield's roots stretch much deeper than Palo Alto's. Mayfield began as a town around 1853. This early period of Mayfield's history was characterized by the introduction of resource extraction activities. In Mayfield's case, farming and lumber harvesting were the predominant industries. At this point in California's history, many towns sprang up at the crossroads of routes for stagecoaches and wagons, which were the main modes of travel. One of these towns was Mayfield, near the intersection of today's El Camino Real and California Avenue. ${ }^{81}$

These early years can be described as Mayfield's most prosperous time. This is largely due to the shipping of lumber and grain through the area. However, after several decades of growth the local economy in Mayfield slowed significantly. Few new buildings were constructed. The salon industry became the main driver of the local economy. Construction of the university (Leland Stanford Junior University) provided

\footnotetext{
${ }^{80}$ Ward Winslow, Palo Alto: A Centennial History (Palo Alto: Palo Alto Historical Association, 1993), ${ }^{2 .}{ }^{81}$ Ibid., 3.
} 
some economic momentum and gave Mayfield new life late in the 1880s. What is now known as the College Terrace neighborhood became part of Mayfield in $1891 .{ }^{82}$

With the construction of the San Francisco to San Jose train line, many San Francisco businessmen began to obtain large peninsula estates. ${ }^{83}$ Mayfield was a wellestablished community by the time when the area that was to become Palo Alto began to take shape less than two miles to the north. Around this same time, the first six families moved to Palo Alto and soon thereafter (1894) it formed its own government. ${ }^{84}$

Palo Alto incorporated approximately 10 years before Mayfield, even though Mayfield was the original settlement in the area. By the time of incorporation, there were significant differences between Palo Alto and Mayfield. Generally speaking, residents of Palo Alto had a higher education level and, to some degree, were wealthier than the residents of Mayfield, which was primarily a blue-collar community. ${ }^{85}$

The Town of Mayfield followed suit and incorporated in 1903. However, at the time "eight saloons patronized by rowdy Stanford students, farm workers, and townspeople were the only lucrative businesses in town."86 The town's growth had stalled because the influx of new residents as well as trades people had been diverted to Palo Alto which was seen as being less rough around the edges. In fact, Palo Alto actively marketed itself as a university town as opposed to a remnant from the Wild West. Palo Alto possessed attractive new homes and strove to be an intellectual and educational center. Palo Alto residents voted to ban saloons in $1905 .^{87}$

Both Mayfield and Palo Alto had their own train stations located near their respective downtowns. Southern Pacific Railroad ran a commuter line from the very first year that Palo Alto was established. ${ }^{88}$ This meant people were commuting to San Francisco from Palo Alto via rail daily. The California Avenue station served Mayfield's downtown, and would have drawn riders more from the Mayfield and south Palo Alto residential neighborhoods to catch the train. If one were living down in that part of the peninsula at the time, and one's job was in San Francisco (because there was no Silicon Valley at that time), the train was definitely the way to get there.

After several additional decades, on July 6, 1925, Palo Alto annexed Mayfield, and Mayfield's 1,700 residents were added to the existing 9,000 Palo Altans. ${ }^{89}$ Despite their long history of growth in close proximity, Mayfield's distinct background and traditions still remain strong in the minds of local residents.

\footnotetext{
${ }^{82}$ Ibid., 28.

${ }^{83}$ Ibid., 3.

${ }^{84}$ Ibid., 23.

${ }^{85}$ Steve Staiger, interview by author, Palo Alto, CA, August 12, 2010.

${ }^{86}$ Winslow, Palo Alto, 30.

${ }^{87}$ Ibid.

${ }^{88}$ Staiger, interview by author.

${ }^{89}$ Winslow, Palo Alto, 33.
} 
Mayfield had continued to develop as a separate town until its annexation to Palo Alto in 1925. Its main commercial street, California Avenue, became a second business district for the city as the land between Mayfield and University Avenue had rapidly been developed. The California Avenue area's value as a transit hub and proximity to Stanford Research Park has increasingly been identified as a strategic location for future growth in Palo Alto. ${ }^{90}$ During the following years, the California Avenue area developed with less public scrutiny as the downtown area. Some early commercial architecture and storefronts are still visible, but most were covered over.

The original gridiron street pattern still exists and there have not been many lot mergers, which has preserved the smaller lot pattern with many different owners. Most buildings along California Avenue are two stories tall, and parking is rear placed with access by alleys. The pre-automobile scale of development provides an environment that is comfortable for pedestrians and bicyclists. Recently, new businesses have been moving into the area, and there is renewed interest from the city in infrastructure upgrades including streetscape projects. An emphasis has been placed on preserving its unique character. $^{91}$

Today, California Avenue is viewed as a smaller second main street, which is also served by a multimodal transit station. It is considered more local-serving than the University Avenue main street. California Avenue is the closest business district to employees and visitors to Stanford Research Park and portions of Stanford University. It is the oldest part of the City of Palo Alto, with origins dating back to the Town of Mayfield. One way in which California Avenue has successfully embraced its past is through the public art murals that decorate the walls of many pedestrian alleyways and building walls of local businesses in the area. The following five pictures showcase examples of these murals. See Figures 1-5 below.

${ }^{90}$ City of Palo Alto, Planning and Community Environment Department, Enhancing the New Century: Palo Alto Comprehensive Plan 1998-2010 (1998), L-4.

${ }^{91}$ Ibid., L-25. 


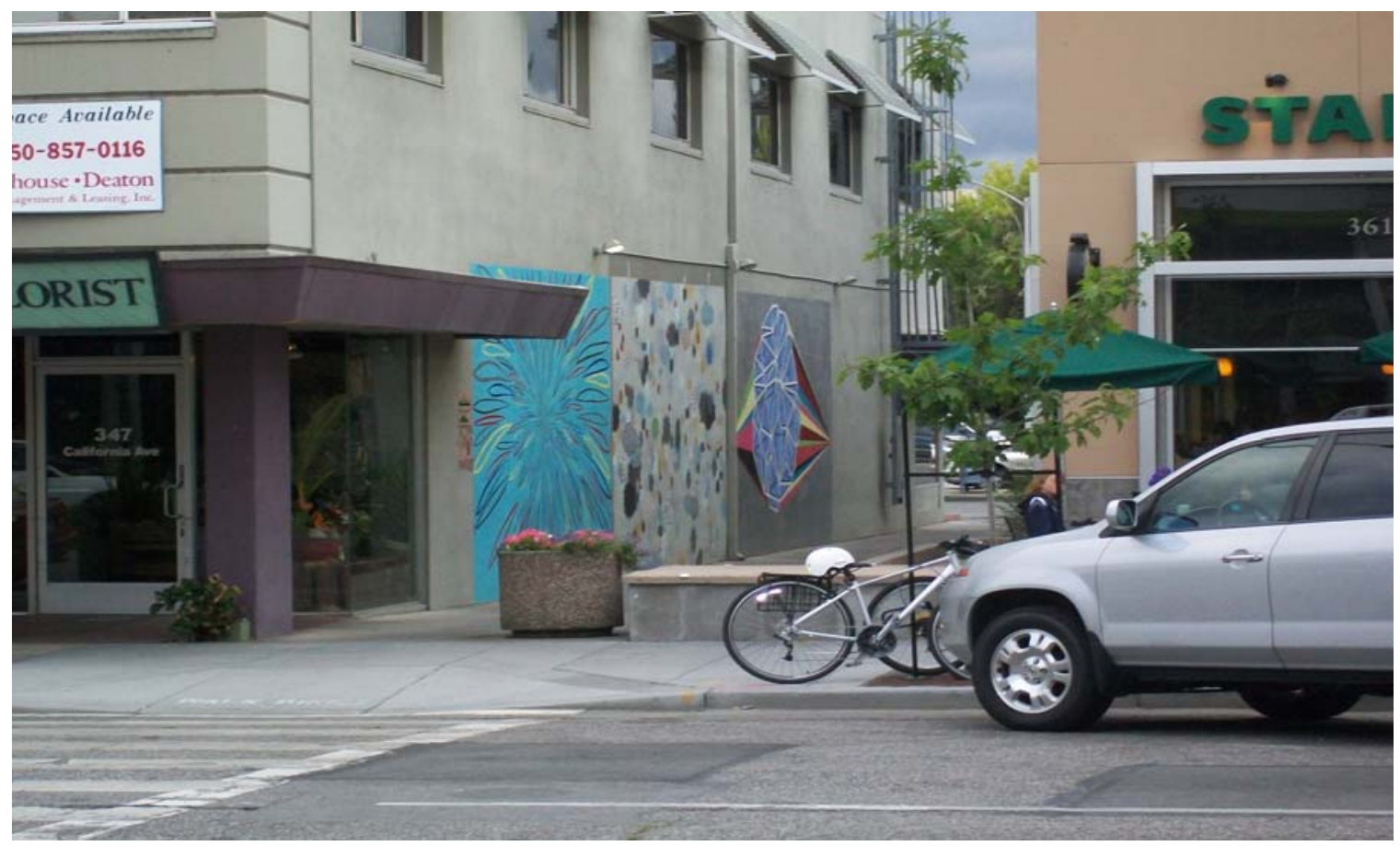

Figure 1: Public art murals on the wall of a pedestrian alley on California Avenue in Palo Alto. Photograph by author.

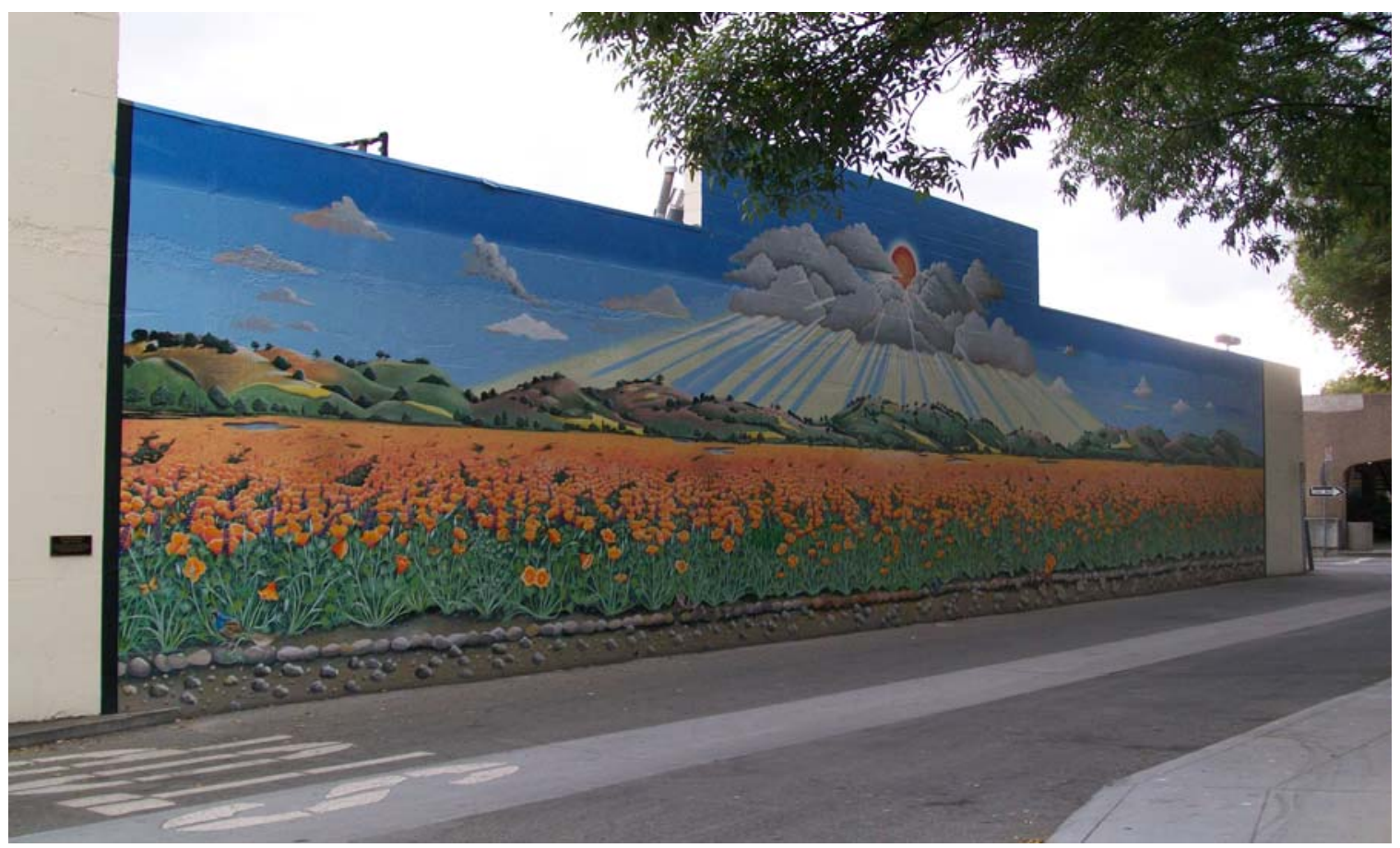

Figure 2: Public art mural on the wall of Country Sun Natural Foods on California Avenue in Palo Alto. Photograph by author. 


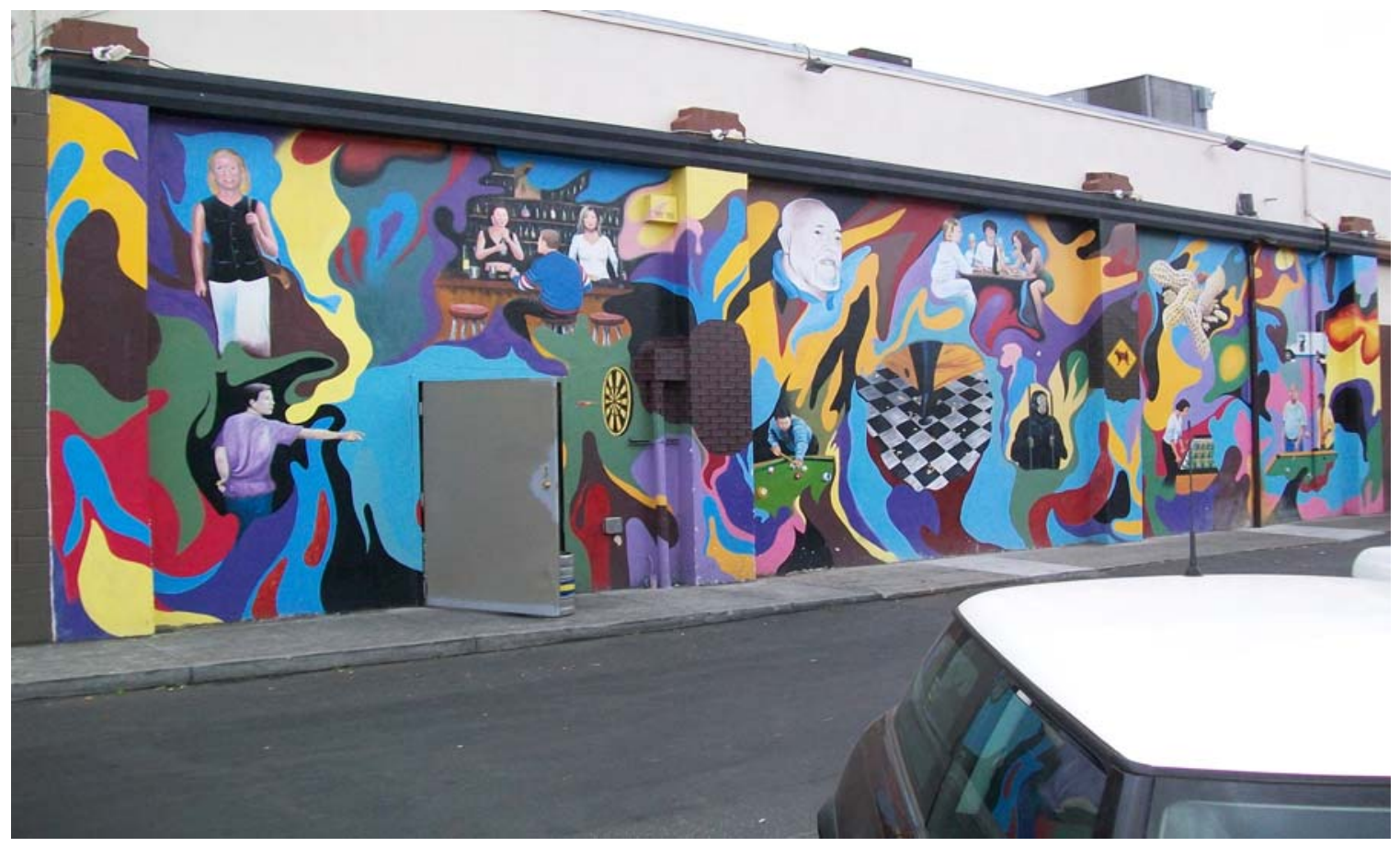

Figure 3: Public art mural on wall of Antonio's Nut House on California Avenue in Palo Alto. Photograph by author.

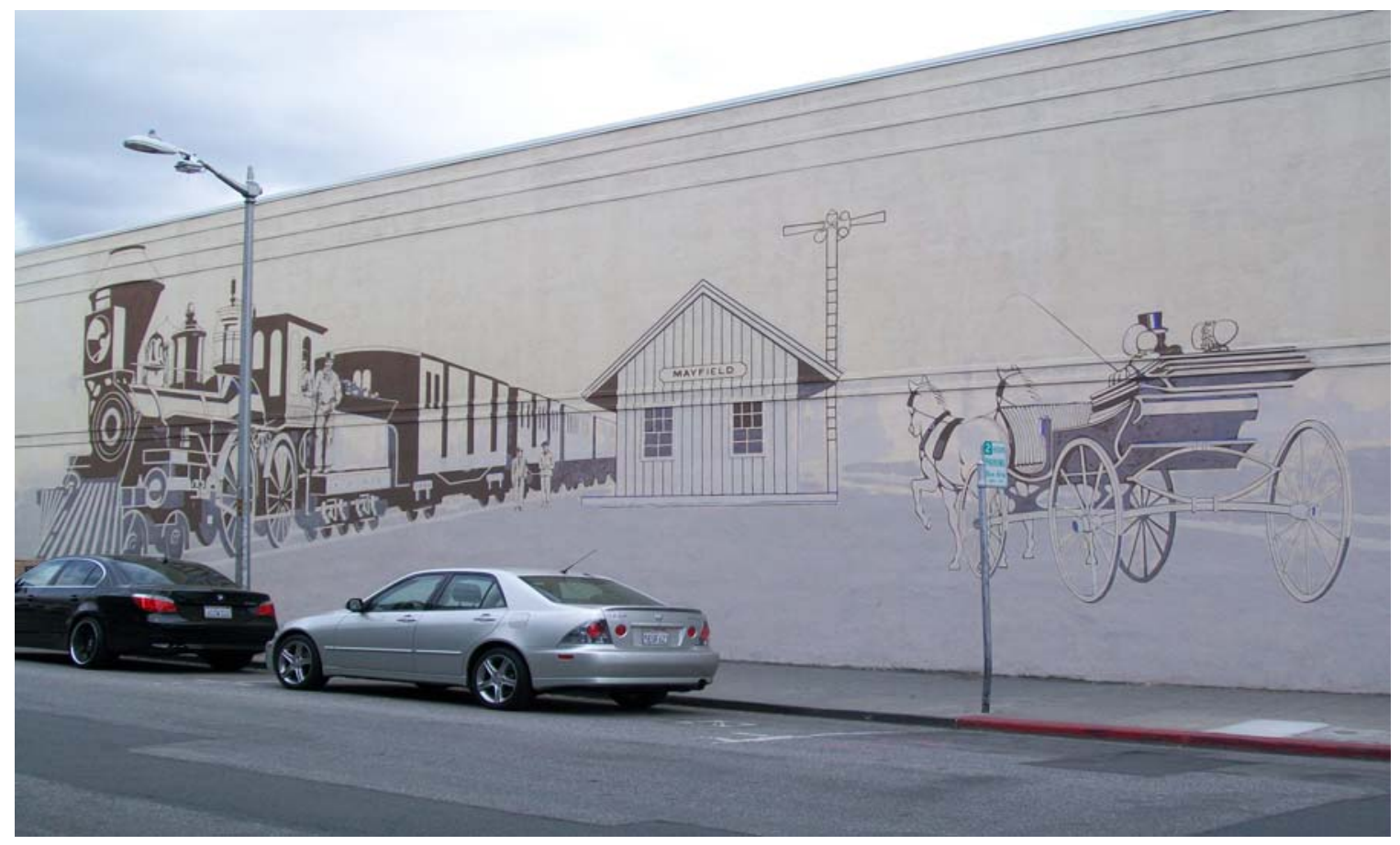

Figure 4: Public art mural depicting the old Mayfield station on the wall of a building on California Avenue in Palo Alto. Photograph by author. 


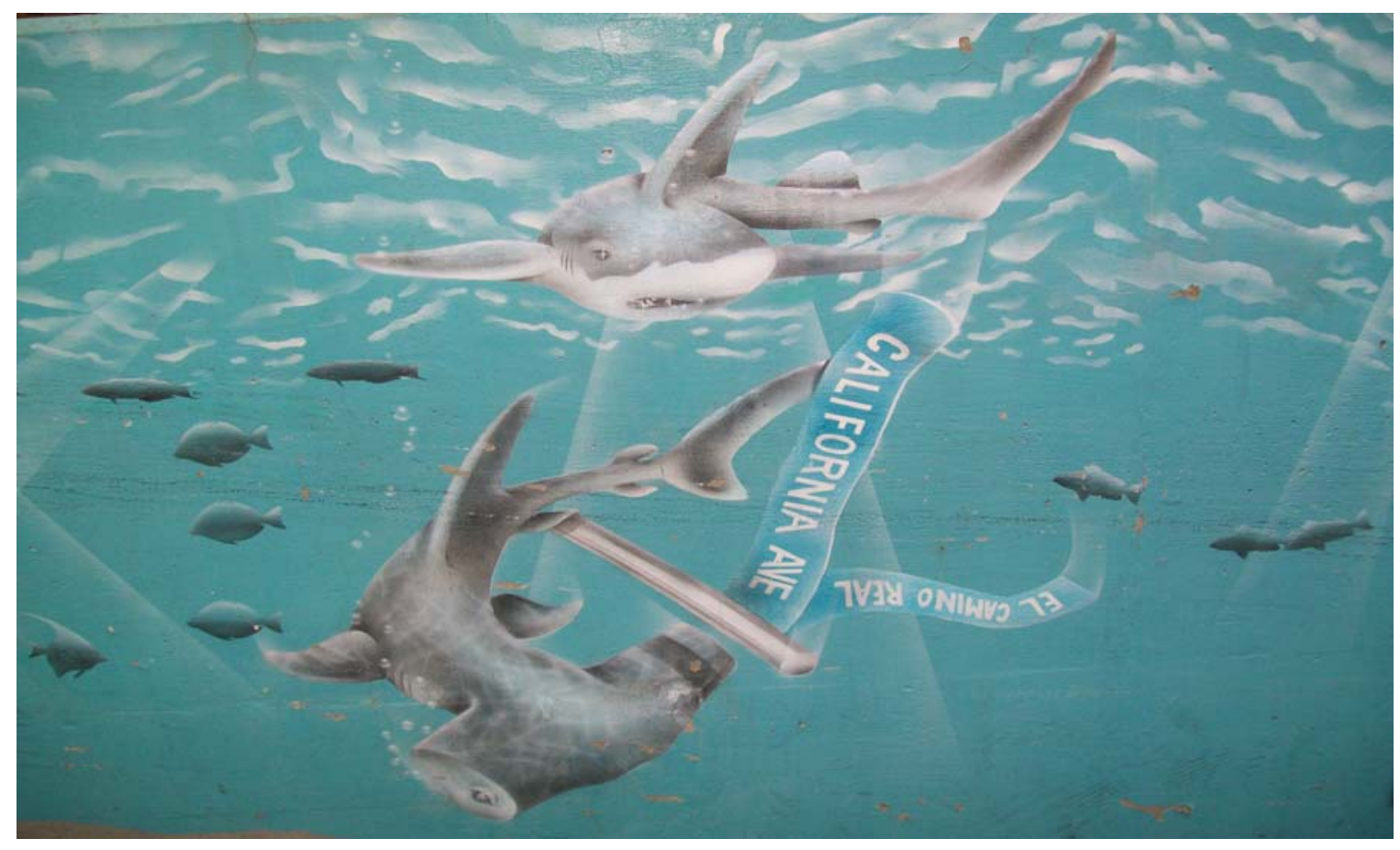

Figure 5: Public art in underground pedestrian tunnel leading to the California Avenue station in Palo Alto. Photograph by author.

\subsection{Leland Stanford}

Railroad baron and politician, Leland Stanford, moved from Sacramento to San Francisco around 1874. Soon thereafter, he began looking for a location to build a stock farm to breed race horses. Within two years, he had found a suitable country property by the banks of the San Francisquito Creek. It was there he began to build what became his Palo Alto Stock Farm. Stanford continued to assemble land in the area by purchasing adjacent ranches in the area, and his estate eventually grew to more than 8,000 acres. ${ }^{92}$

The 1884 death of their only child, Leland, Jr., led to a change of course. Stanford and his wife made the decision to create and endow a university as a memorial to their son. The location that was chosen for the university would be their Palo Alto Stock Farm. ${ }^{93}$ The founding of the university led to the eventual establishment of the City of Palo Alto.

The close proximity of Stanford University to Palo Alto means their shared roots can lead to increased future collaboration. ${ }^{94}$ The past and futures of the two entities will be forever connected. "Some of the most significant opportunities for growth and change in the Palo Alto vicinity are on Stanford University lands." ${ }^{~}$ In fact, while the Stanford

\footnotetext{
${ }^{92}$ Winslow, Palo Alto, 2.

${ }^{93}$ Ibid., 35.

${ }^{94}$ Ibid., 1 .

${ }^{95}$ City of Palo Alto, Enhancing the New Century, L-3.
} 
campus itself is located in unincorporated Santa Clara County, much of the university's income-producing lands are within Palo Alto. These lands include the Stanford Research Park and Stanford Shopping Center. This means that the city has jurisdiction over many of the activities that take place there.

Fortunately, the City of Palo Alto and Stanford University share a similar outlook toward growth. The city and Stanford have many opportunities to support these shared goals through collaboration on projects located both on and off Stanford University lands. ${ }^{96}$ The relationship between the city and university has been complex and tense at times, but overall there have been mutual benefits. Their close proximity has led to many opportunities for collaboration when conducting land-use and planning activities. Some recent land-use and transportation planning collaborations have included the University Avenue transit station and expansion of the university's Marguerite Shuttle Bus within the city. ${ }^{97}$ The city can look to Stanford University as a partner when planning for future growth.

\subsection{Palo Alto}

The name Palo Alto refers to the once tall redwood tree near the banks of the San Francisquito Creek, where early Spanish explorers first camped. ${ }^{98}$ In Spanish it literally means tall tree. Since the first explorers arrived the population of Palo Alto and the region as a whole has skyrocketed. "In the century since its incorporation as a city in April 1894, Palo Alto’s population has grown to nearly 59,000 and its area from 737.55 acres (1.15 square miles) to 25.98 square miles."99 Palo Alto remains a leader in quality of life, education, and technological innovation.

Palo Alto was originally known as University Park, and generally included the land bounded by San Francisquito Creek, Embarcadero Road, the railroad, and Middlefield Road. ${ }^{100}$ It got its start in 1890 , when lots in the town, which had recently been subdivided, were auctioned. Palo Alto was created by Leland Stanford as a dry town. In fact, there was a deed restriction on properties that prohibited the sale and manufacture of alcohol. This stood in contrast to the neighboring community of Mayfield, whose residents did not agree to become a dry town. The reason for Stanford's insistence on this was not his religion, but because he was a politician. ${ }^{101}$ Whatever the actual reason, this slight distinction resulted in two divergent paths for the communities.

The City of Palo Alto, with its close relationship to the university, valued education at all levels from the very beginning. Mayme Bass Suiter, the principal of the first Palo Alto school in 1893, recalled her early pupils: "The children came from all over

\footnotetext{
${ }^{96}$ Ibid.

${ }^{97}$ Ibid.

${ }^{98}$ Staiger, interview by author.

${ }^{99}$ Winslow, Palo Alto, 1.

${ }^{100}$ Ibid., 41.

${ }^{101}$ Staiger, interview by author.
} 
the world," she said. "They were mostly younger brothers and sisters in families who had come here so their older offspring could attend Stanford.”102 Palo Alto was a university town from the very beginning and, in many ways, was planned to serve the university. This resulted in a populace that valued and sought education.

The two towns continued to develop around their own downtowns: Mayfield with California Avenue and Palo Alto with University Avenue. In the years that followed, Palo Alto was thriving while Mayfield was not growing as quickly. Around this time, there was a movement for Palo Alto to annex Mayfield. In 1925, Palo Alto did so. The Mayfield library was renamed the South Palo Alto Library, and many steps were taken to transition Mayfield and fold its identity into Palo Alto’s. Some residents of Mayfield perceived the move as an effort that was intended to replace Mayfield's identity entirely. In fact, some old-time residents have proudly identified themselves as residents of Mayfield, as opposed to Palo Alto, as recently as the 1960s and 1970s. ${ }^{103}$

Palo Alto saw its largest expansion during the decade after World War II. The city continued to annex land to the south and east, which resulted in its boundary expanding south to Mountain View and the city's residential land area nearly doubling. The original town center was the commercial district along University Avenue, although the geographic center of the city has shifted several miles south. ${ }^{104}$ New neighborhood shopping centers, such as Alma Plaza and Midtown, were developed to serve the growing suburban population. All of the new residents needed places to work, which resulted in much of the city's commercial land being annexed in the 1950 s. ${ }^{105}$ This period of expansion coincided with the transformation of the city from a university town to a world leader in technology.

Currently, Palo Alto’s land area consists of approximately 26 square miles. Over half of this area has been dedicated as natural areas in parks and preserves (Foothills Park and the Baylands Nature Preserve). Most of the remaining area within the city's boundaries is built-up, with single-family residential uses predominating and less than one percent of the total land area consisting of vacant land. ${ }^{106}$ This reality has led to a renewed focus on future growth through infill and redevelopment. In a community survey conducted during the comprehensive plan process, the community overwhelmingly reaffirmed its commitment to the protection of the Baylands and Foothills. It is possible to shift the city's growth pattern to one based on infill development while also protecting the community qualities that are valued in Palo Alto. ${ }^{107}$ To ensure that future development is successful, a collaborative approach must be undertaken.

\subsection{Transportation}

\footnotetext{
${ }^{102}$ Winslow, Palo Alto, 43.

${ }^{103}$ Staiger, interview by author.

${ }^{104}$ City of Palo Alto, Enhancing the New Century, L-3, L-4.

${ }^{105}$ Ibid., L-4.

${ }^{106}$ Ibid.

${ }^{107}$ Ibid., L-5.
} 
Until the first Spanish explorers arrived on horseback, walking was the main means of locomotion in the San Francisco Bay Area. As was the case in many areas, footpaths and trails first established by the native people eventually developed into the first roads. In summer, a trail that meandered roughly along today’s Middlefield Road was favored, because it was shorter and had an easy crossing at San Francisquito Creek. ${ }^{108}$ However, during the rainy season, the higher road was most often travelled. This higher road was the one favored by the Spanish explorers and missionaries. This eventually resulted in travel promoters in the early 20th century titling it El Camino Real, (The King's Highway, in Spanish) to commemorate the original Spanish expeditions. ${ }^{109}$

Back when the area was first settled, a trip from the northwest Santa Clara Valley to San Francisco would have taken several days. Surveyors laid out what is now called El Camino Real in the 1850s; its original name was simply the San Francisco to San Jose Road. ${ }^{110}$ The road allowed the first four-wheel vehicles, including stagecoaches and wagons, a fairly direct route between the two cities. For decades before the Bayshore Highway and then the Bayshore Freeway, were built, El Camino Real was the main thoroughfare for traffic up and down the peninsula. ${ }^{111}$ Demand was so great that a stagecoach line between San Jose and San Francisco started in September 1849, at a cost of $\$ 32$ per passenger. By 1853, additional competition had driven the price of a one-way fare down to $\$ 10 .{ }^{112}$

The San Francisco to San Jose Railroad reached Mayfield in 1863. Soon thereafter, regular two-trains-a-day service between Mayfield and San Francisco began operation. The extension of the line to San Jose was completed early in $1864 .{ }^{113}$ This was to be the beginning of passenger service up and down the peninsula. A local philanthropist (William Paul) facilitated the shift of the station location to where the current California Avenue station now stands by donating free land for the new depot. ${ }^{114}$

By 1870, the railroad was controlled by Southern Pacific Company, which continued to run two trains each way daily. ${ }^{115}$ This marked the beginning of commuter rail service in Palo Alto, and it continues to this day via Caltrain. Around this time, trains in general were becoming the favored means of intercity transportation. The original depot established at California Avenue in 1869 served until 1954, when a new building replaced it. ${ }^{116}$ The current California Avenue station was built along with the adjacent Palo Alto Central mixed-use development.

\footnotetext{
${ }^{108}$ Winslow, Palo Alto, 2.

${ }^{109}$ Ibid.

${ }^{110}$ Ibid., 147.

${ }^{111}$ Ibid.

${ }^{112}$ Ibid., 148.

${ }^{113}$ Ibid., 149.

${ }^{114}$ Ibid., 26.

${ }^{115}$ Ibid., 149.

${ }^{116}$ Ibid., 150.
} 
The first Palo Alto train station was located at University Avenue and the railroad tracks. An early resident, Susan K. Branner, wrote the following of her family's arrival by train in Palo Alto in 1891: “. . . when we finally stepped off at Palo Alto, we found a small platform for a station. Not a house or building of any kind was in sight. What is now Palo Alto was an open field apparently stretching away for miles . .."117 However, plans were already in motion to change that. Landscape architect Fredrick L. Olmstead had been retained by Senator Stanford to revise campus plans to provide a direct connection (via Palm Drive) to a proposed downtown Palo Alto rail station. ${ }^{118}$

Around that time a wood-frame station was built on the campus side of the tracks. In 1941, the Southern Pacific Railroad built a new modern style station, which still remains today. ${ }^{119}$ Commuter service continued to expand. By 1954, commute service reached a peak of 16,000 commuters carried daily on board the trains. ${ }^{120}$ The main depot remained on the campus side of the tracks with a smaller shelter on the downtown side of the tracks.

After the completion of new freeways in the 1950's, many rail passengers were drawn away from rail service and onto the recently completed interstate highway system. As their numbers grew, autos changed the appearance of Palo Alto as was the case, sooner or later, almost everywhere in the nation. By 1980, with support from the California Transportation Agency, Caltrain was created to operate commuter service, and the Palo Alto station was rehabilitated. ${ }^{121}$ Around this time, the Palo Alto station became a regional transit hub serving both Santa Clara County and San Mateo County bus and shuttle passengers as well as Caltrain rail commuters. Since that time, a number of factors, including reverse commutes to peninsula and Silicon Valley jobs, helped boost Caltrain ridership to more than 23,000 passengers a day in the early 1990 s. $^{122}$

Before the completion of the freeway, commute traffic was primarily restricted to the morning with people rushing from their houses to catch the train and with the reverse commute in the evening. Palo Alto was primarily residential in character and traffic issues were not yet on the radar. The only time traffic congestion was an issue was a few Saturdays per year when there was a major football game at Stanford University. ${ }^{123}$ Today, many of the main roads used to access Palo Alto and its job centers are thoroughly congested during commute times. This reality is yet another reason that the city has identified TOD as a promising form for future infill and redevelopment.

Palo Alto was one of the first in the nation to dedicate a formal bicycle system. Since that time, the city has continued to support bicycling and has planned for expanded infrastructure. This includes coordinating planning with neighboring communities to overcome barriers to bicycle travel in and around Palo Alto. Today, Palo Alto's bicycle

\footnotetext{
${ }^{117}$ Ibid.

${ }^{118}$ Ibid.

${ }^{119}$ Ibid.

${ }^{120}$ Ibid., 151.

${ }^{121}$ Ibid.

${ }^{122}$ Ibid., 153.

${ }^{123}$ Staiger, interview by author.
} 
system includes both on- and off-road bicycle lanes, as well as pedestrian paths and bridges. ${ }^{124}$ Palo Alto continues to actively plan for pedestrian and bicycle infrastructure improvements.

Palo Alto has also made great progress through its bicycle parking requirements for new construction. As a result, bicycle parking can be found at most recently developed destinations. However, the city has identified areas where additional bicycle parking is still needed, including parts of downtown. In addition, secure bicycle parking at multimodal transit stations, such as California Avenue, has been identified for improvement. Another important improvement is the acceptance by transit operators of bicycles on buses and trains, but capacity is limited. Palo Alto has several policies and programs in place to continue to promote improved and expanded bicycle infrastructure and continues to work with public transit operators to increase onboard capacity. ${ }^{125}$

\subsection{Growth and Industry}

For much of its early history, Palo Alto was primarily residential in nature-the exception being the city's downtown commercial core. The main impetus for change was when Stanford University transitioned from being a university to a major employer. Also, in the early 1950s, the concept of the industrial park or research park was first introduced. The Stanford Research Park was being built up prior to 1950, with the first tenant moving in around 1952-1953. ${ }^{126}$ What that did was create a tax basis in town, but with it came the undesired side effect of traffic congestion.

The development and growth of the Stanford Research Park led to the creation of many jobs, and resulting traffic congestion, when the workers would all arrive and depart in that part of town. There were limited freeways at the time, and that left commuters the option of taking El Camino Real or the residential streets. This is really when traffic congestion may have first been perceived by residents of the maturing city. ${ }^{127}$

Almost all negative perceptions of growth during this time were traffic related. Once workers got to the Stanford Research Park, they were out of sight and out of mind. During the late 1950s, the Stanford Hospital relocated from San Francisco to the Stanford Medical School in Palo Alto. ${ }^{128}$ This represented another traffic generator and associated traffic issues on the north side of campus. All this traffic had to drive through Palo Alto to get to Highway 101, as it still does today.

Around this same time (the late 1950s), Palo Alto also saw the development of the Stanford Shopping Center. It was one of the first regional shopping centers developed in

\footnotetext{
${ }^{124}$ City of Palo Alto, Enhancing the New Century, T-9.

${ }^{125}$ Ibid., T-14.

${ }^{126}$ Staiger, interview by author.

${ }^{127}$ Ibid.

${ }^{128}$ Ibid.
} 
California. ${ }^{129}$ Previously, many of the people who shopped at the Stanford Shopping Center would have shopped at their local downtown or taken a trip to San Francisco. When the Stanford Shopping Center first opened, it had a hardware store, a Woolworth's, a grocery store, and an emporium (Brooks Brothers) department store. ${ }^{130}$ Most of the early stores were branches from San Francisco.

Residential development in Palo Alto between the end of World War II and the 1960s was skyrocketing. Developers like Joseph Eichler (a prominent local developer) and his competitors were building like crazy. The population more than doubled in that short time. ${ }^{131}$ This exponential growth resulted in a variety of public perceptions on growth and development in general. The population in 1960 and 2000 was about the same, and has gone up only slightly in the last few years. ${ }^{132}$ The population in Palo Alto during that 40-year period was essentially flat, with no population growth. One reason for this halt in growth was there was no place to easily grow. Palo Alto was essentially built out on all sides.

Since that time, there has been a slow, but distinct change in the demographics of the population of Palo Alto. In the 1950s, Palo Alto primarily had larger families with anywhere from three to six kids. ${ }^{133}$ Over time, the number of households has increased only slightly, but at the same time the family size has dropped off, so the result is the population has remained relatively constant with a slight uptick over time, since the boom years.

\footnotetext{
${ }^{129}$ Ibid.

${ }^{130}$ Ibid.

${ }^{131}$ Winslow, Palo Alto, 2.

${ }^{132}$ Staiger, interview by author.

${ }^{133}$ Ibid.
} 


\section{CHAPTER 5: EXISTING POLICIES AND REGULATIONS}

\subsection{Introduction}

There are many local policies and regulations that apply to new development in the City of Palo Alto in general and the California Avenue area specifically. This chapter will review the City of Palo Alto’s long-range policy document, known as the comprehensive plan. A discussion will follow each quoted policy and will serve to interpret and provide suggestions for future modifications. The chapter will also cover the update that is currently underway for the housing element, and the newly designated California Avenue Concept Plan. Next there will be a review of the zoning ordinance update process and a review of Chapters 18.34 and 18.52 of the PAMC. The chapter will conclude with a discussion of a current TOD project and related topics.

\subsection{Comprehensive Plan}

California law requires that every city and county in the state produce and adopt a general plan which describes policies and principles for growth and development within the jurisdiction's boundaries over the long term. In Palo Alto, this plan is known as the Comprehensive Plan. The comprehensive plan is the most important policy document that guides future development in the city. The seven state-mandated elements for local plans are land use, circulation, housing, open space, conservation, safety, and noise. ${ }^{134}$

The Palo Alto Comprehensive Plan has seven major themes:

1. Building community and neighborhoods

2. Maintaining and enhancing community character

3. Reducing reliance on the automobile

4. Meeting housing supply challenges

5. Protecting and repairing natural features

6. Meeting residential and commercial needs

7. Providing responsive governance and regional leadership ${ }^{135}$

Within the City of Palo Alto's Comprehensive Plan, a goal is described as a general end toward which the city will direct effort. A policy is a specific statement of principle or of guiding actions that implies clear commitment, but is not mandatory. A program is an action, activity, or strategy taken in response to an adopted policy in order to achieve a specific goal or objective. ${ }^{136}$ These three terms are used to provide direction on how growth and development should occur in the city.

\footnotetext{
${ }^{134}$ City of Palo Alto, Enhancing the New Century, I-2.

${ }^{135}$ Ibid., I-2, I-3.

${ }^{136}$ Ibid., I-4.
} 
Section 5.3 will introduce and discuss the transit-oriented goals, policies, and programs from three of the seven elements (land use, transportation, and housing) contained in the City of Palo Alto's Comprehensive Plan. The discussion will serve to interpret and provide suggestions for future modifications.

\subsection{Evaluation of Comprehensive Plan Goals, Policies, and Programs}

\section{Land-Use Element}

Program L-14: “Create and apply zoning standards for Transit-Oriented Residential housing prototypes, including consideration of minimum density standards. Develop design guidelines that ensure that such housing is compatible with the University Avenue/downtown and California Avenue centers where it may be permitted.”137

This program has already been accomplished, in part, by the 2006 adoption of chapter 18.34 of the zoning ordinance (Pedestrian and Transit-Oriented Development [PTOD] Combining District Regulations) and the context-based design criteria contained therein. At the current time, the regulations only apply to the California Avenue station with the section on University Avenue/downtown being reserved for future adoption. The PTOD regulations did not include minimum-density standards, although they were considered in the policy formation process. The PTOD regulations could be improved in the future through the addition of minimum-density standards.

Policy L-28: "Maintain the existing scale, character, and function of the California Avenue business district as a shopping, service, and office center intermediate in function and scale between downtown and the smaller neighborhood business areas." "138

This policy has been accomplished, to some extent, through numerous community meetings with neighborhood stakeholders to ensure that any new development in the area respects their perception of what the district should be. These meetings have been in conjunction with the current California Avenue Specific Area Plan effort, and in preparation for a road narrowing project partially funded through a VTA grant. The idea of maintaining the existing scale of the district as intermediate in function and scale between downtown and smaller neighborhood business areas may need to be revisited. California Avenue holds great potential for accommodating the city's future growth in a transit-oriented manner, but to what extent it will achieve success will depend heavily on the scale of future development. If development is limited in scale to what is currently there, a significant opportunity may be lost.

Program L-27: “Create regulations for the California Avenue area that allow for the replacement or rehabilitation of smaller buildings while preventing buildings that are out of scale with existing buildings." 139

\footnotetext{
${ }^{137}$ Ibid., L-18.

${ }^{138}$ Ibid., L-24.

${ }^{139}$ Ibid., L-24, L-25.
} 
This program has a similar response to the previous policy. Many of the existing commercial buildings along California Avenue are considered legal nonconforming, as in many cases, they are larger than the current regulations would allow. It may be wise to revisit this program to allow higher-density development after careful discussion with neighboring stakeholders. The California Avenue area holds great potential for accommodating the city's future growth in a transit-oriented manner, but to what extent it will achieve success will depend heavily on the scale of future development.

Program L-28: "Work with merchants, property owners, and city representatives to create an urban design guide for the California Avenue business district.”140

This program has already been accomplished, in part, by the 2006 adoption of the PTOD regulations and the Context-Based Design Criteria contained therein. The Context-Based Design Criteria provide urban design guidelines that are required for new development in the California Avenue area. These design criteria could be revisited and revised in the future to ensure that the desired built form is being achieved.

Policy L-29: "Encourage residential and mixed-use residential development in the California Avenue area."141

This policy has already been addressed, in part, through the 2006 adoption of the PTOD regulations. The PTOD regulations include development standards that allow an increased floor area ratio for mixed-use development within the California Avenue area. The development standards could be revisited in the future, and increased with community support, to provide a more vibrant pedestrian and transit-oriented environment.

Program L-78: “Encourage the use of Planned Community (PC) zoning for parking structures downtown and in the California Avenue area."142

This program has seen little if any recent action in the California Avenue area. The vast majority of parking in the area is made up of city-owned, surface parking lots, placed at the rear of the commercial buildings that line California Avenue. This pattern is present along much of the corridor and represents perhaps the biggest opportunity for redeveloping and revitalizing the California Avenue area. Several parking structures have been built downtown and the results have been overwhelmingly positive. This program should be carefully carried over to the California Avenue area in order to achieve similar benefits.

\footnotetext{
${ }^{140}$ Ibid., L-25.

${ }^{141}$ Ibid.

${ }^{142}$ Ibid., L-49.
} 


\section{Transportation Element}

Policy T-1: "Make land-use decisions that encourage walking, bicycling, and public transit use. Transportation and land use are inextricably linked. Low-density land-use patterns generally dictate the use of an automobile, while higher-density and mixed-use patterns generally translate into higher transit usage and pedestrian activity. Transit stations and bus routes present opportunities for higher-density development. Palo Alto recognizes the relationship between transportation and land use and will promote a landuse pattern that supports walking, bicycling, and reduced dependence on cars." ${ }^{\text {"143 }}$

This policy has been employed, to some extent, but there is still much room for improvement. For example, as recently as 2004 and 2005, new multifamily housing projects were approved in areas of the city that are neither mixed-use nor near transit. The city has since acknowledged the shortcomings of these projects and reaffirmed its commitment to increased density in transit-oriented, mixed-use neighborhoods. However, several of the policies in the land-use element seem to be inconsistent. For example, the California Avenue area holds perhaps the greatest potential for a mixed-use, transitoriented neighborhood, but its future development seems to be limited to the scale of the existing primarily one- and two-story development pattern. These policies and programs should be revisited to ensure they are consistent and supportive of the underlying goals of the city.

Program T-1: "Encourage infill, redevelopment, and reuse of vacant or underutilized parcels employing minimum density requirements that are appropriate to support transit, bicycling, and walking."144

This program has yet to achieve great success in the California Avenue area. For example, there are still many underutilized parcels consisting primarily of surface parking lots that hold tremendous potential for transit-oriented, mixed-use, infill development. To achieve the greatest success, these parcels must be developed with minimum-density regulations. This will ensure that an appropriate density is achieved in order to support a high-quality transit service level. Also, by employing the Context-Based Design Criteria, the pedestrian and bicycling environment will be enhanced. The pedestrian tunnel shown in Figure 6 is an excellent example of pedestrian and bicycling infrastructure that supports those modes.

\footnotetext{
${ }^{143}$ Ibid., T-2.

${ }^{144}$ Ibid.
} 


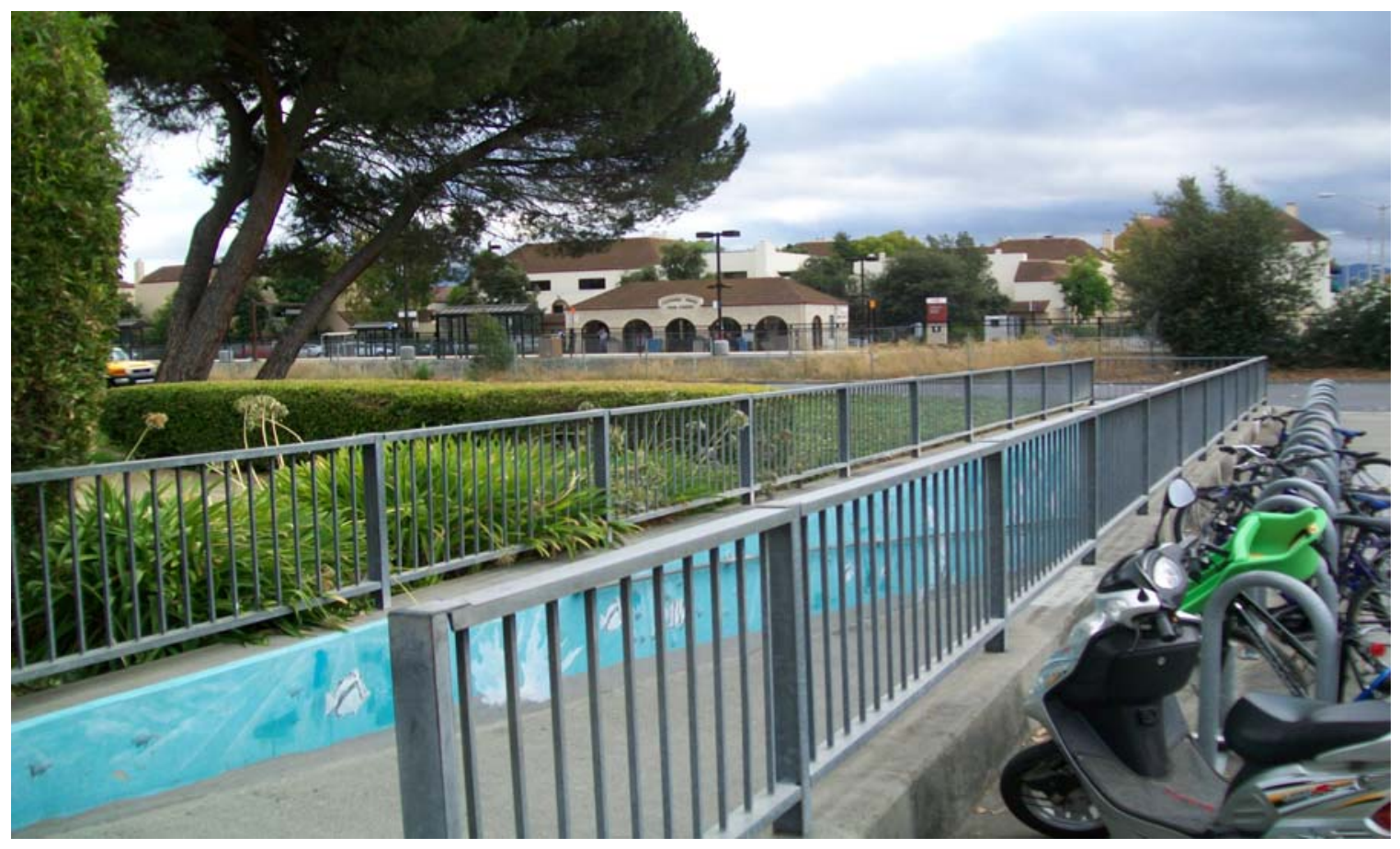

Figure 6: View of California Avenue Caltrain station with pedestrian tunnel entrance in foreground. Photograph by author.

Program T-2: "Promote mixed-use development to provide housing and commercial services near employment centers, thereby reducing the necessity of driving." "145

This program has yet to achieve success in the California Avenue area. California Avenue is located between one of the city's largest employment centers (Stanford Research Park) and the California Avenue multimodal transit station. It represents an excellent opportunity to provide housing and commercial services near an employment center, thereby reducing the necessity of driving. However, some of the city's comprehensive plan land-use policies seem to stand in opposition to this goal by limiting the scale of future development to that of the existing buildings. The city should seek to remedy this situation by providing a clearer picture of what is acceptable in the area, as well as continuing to upgrade the infrastructure to support this goal.

Program T-3: "Locate higher-density development along transit corridors and near multimodal transit stations."

This program has yet to achieve success in the California Avenue area. While some new high-density buildings have been built near the downtown station, few, if any, have been built in the California Avenue area. This lack of higher-density development may be partially due to inconsistencies in the comprehensive plan, and also because of community opposition to higher-density development in the California Avenue area.

\footnotetext{
${ }^{145}$ Ibid., T-3.

${ }^{146}$ Ibid.
} 
Future revisions should seek to provide a clearer and more consistent picture of what the community's vision is for the future of the California Avenue area.

Program T-8: “Create a long-term education program to change the travel habits of residents, visitors, and workers by informing them about transportation alternatives, incentives, and impacts. Work with the Palo Alto Unified School District and with private interests, such as the Chamber of Commerce, to develop and implement this program."

This program has been met with moderate success. For example, Palo Alto currently has a high percentage of school-aged children who bicycle to school. Also, the city has been very proactive in implementing Transportation Demand Management (TDM) programs for new development and in promoting bicycling and transit as commute modes. An area that could use improvement is in educating the community adjacent to the California Avenue station area on how increased density around the transit station can enhance their neighborhood and improve their access to high-quality transit. This effort could work in tandem with efforts to revise certain comprehensive plan policies and programs that may currently be inconsistent or even in opposition.

Policy T-45: "Provide sufficient parking in the University Avenue/downtown and California Avenue business districts to address long-range needs.”"148

This policy has yet to achieve success in the California Avenue area. As mentioned above, the majority of parking in the California Avenue area is provided through city-owned surface parking lots. These lots are frequently near capacity throughout the day. It is reasonable to assume that if the city facilitated additional parking in the area it would yield a similar response to what has been observed in the downtown area: increased private developer interest in higher-density development projects.

\section{Housing Element}

Policy H-2: “Identify and implement a variety of strategies to increase housing density and diversity in appropriate locations. Emphasize and encourage the development of affordable and attainable housing."149

This policy has been met with marginal success. For example, there have been some higher-density residential and mixed-use projects developed near the downtown transit station in recent years. However, there have also been several projects that were developed in less than ideal locations during that time. The city should reaffirm and strengthen its commitment to increased density in appropriate locations, and only allow new high-density development in close proximity to high-quality transit.

\footnotetext{
${ }^{147}$ Ibid., T-4.

${ }^{148}$ Ibid., T-25.

${ }^{149}$ Ibid., H-7.
} 
Program H-1: "Increase housing density immediately surrounding commercial areas and particularly near transit stations by either increasing allowed densities or encouraging development at the higher end of the existing density range for sites within 2,000 feet of an existing or planned transit station or along two major transit corridors, El Camino Real and San Antonio Road, wherever appropriate.",150

Again, this program has been met with only marginal success in recent years. Some larger projects are located near transit, but others are just the opposite. The city should revise its comprehensive plan policies and programs to ensure they give a clear direction on where future growth should occur in the city. New high-density development should be restricted to areas that meet these criteria. Otherwise, the results will undermine any progress being made elsewhere in the city.

Program H-10: "Encourage the development of housing on parking lots by adopting incentives that will lead to housing production while maintaining the required parking."

This program has seen no success in the California Avenue area. Again, there are numerous city-owned surface parking lots in the area that are suitable for the type of development described in this program. However, the city has not initiated any such development there. Comprehensive plan policies and programs may need to be revisited to ensure they are mutually supportive of this goal. Also, minimum residential densities will ensure that the development achieves the desired outcome.

Program H-7: "Modify parking requirements to allow higher densities and reduced housing costs in areas appropriate for reduced parking requirements.”152

This program has had some success with the 2006 adoption of the PTOD regulations. These regulations include allowances for increased density development, as well as reduced parking requirements. Reduced parking requirements, in turn, drive down the cost of the housing product. This program should be monitored and revised accordingly to ensure that it is having the desired effect, in light of the absence of minimum-density requirements.

Program H-3: "Evaluate zoning incentives that encourage the development of diverse housing types including smaller, more affordable units and two- and three-bedroom units suitable for families with children.,"153

This program has not had much success yet. The PTOD regulations made some progress through the inclusion of Below Market Rate (BMR) density bonuses and by requiring that the diversity of building types increase with increased lot sizes. However, the California Avenue area is made up primarily of smaller lots owned by many different

\footnotetext{
${ }^{150}$ Ibid.

${ }^{151}$ Ibid., H-12.

${ }^{152}$ Ibid.

${ }^{153}$ Ibid., H-22.
} 
owners, which limits the effectiveness of the diverse housing type requirement. The city should revisit this program to ensure that the allowable housing types are realistic and will attract a desirable demographic.

Program H-2: "Consider enacting minimum-density requirements in multiple family zones."154

This program has yet to be fully embraced. While minimum density requirements have been considered for multifamily zones (such as in developing the PTOD regulations), they did not ultimately end up being included in the development standards for any residential zoning districts in the City of Palo Alto. The PTOD regulations could be improved in the future through the addition of a minimum-density development standard.

\subsection{Housing Element Update}

The comprehensive plan is the guiding policy document that the City of Palo Alto uses to ensure orderly development in the community. The housing element is one of the seven state-mandated elements and serves as the city's blueprint for future housing growth. The housing element is the only comprehensive plan element, which is required to be certified by the state. The housing element is first adopted by the City Council and then sent to the state for certification. The state agency that does the certification is called the Housing and Community Development (HCD) Department. ${ }^{155}$ Prior to certifying a jurisdiction's housing element, the state undertakes a thorough review to ensure compliance with the required components.

One step the city takes toward certifying its housing element is the review and assessment of the city's existing goals, policies, and programs. This includes a critique with comments on how well or poorly each performed. Another step is to identify any new goals, policies, and programs. For example, the vision for the city may have changed since it was last updated because of the economy or changing times. ${ }^{156}$ The housing element's goals, policies, and programs are updated to reflect and support the community's changing vision. The last step is a housing inventory of potential housing sites. Each RHNA cycle, every COG is allocated a number of housing units by the state. Each COG then devises a methodology to allocate the housing units to local jurisdictions within their region.

The housing element goals, policies, and programs section is continually updated to reflect the changing vision of the city. For example, in Palo Alto, historically developers have not built to the maximum residential density allowed on parcels zoned for multifamily residential. One option that a city has is to put a minimum density requirement in place to help achieve the targets of the housing element. ${ }^{157}$ In this way, the

\footnotetext{
${ }^{154}$ Ibid.

${ }^{155}$ Babiera, interview by author, Palo Alto, CA, September 9, 2010.

${ }^{156}$ Ibid.

${ }^{157}$ Ibid.
} 
housing element update process is used to guide the direction of future policies and programs by identifying places for improvement.

A similar example of how the goals, policies, and programs evolve through this process includes some multifamily housing sites that were built far away from transit. This development occurred despite several policies that stipulated residential development should be transit-oriented. The anticipated result in this housing element cycle is the City Council will give a strong directive (to staff) that their priority in terms of housing sites will be those that are within half a mile of transit stations and within a quarter of a mile of El Camino Real. ${ }^{158}$ These priorities align well with both city and regional planning objectives.

The City Council's new directive would be in contrast to the several sites that were recently developed further out, near Highway 101, in an industrial area without good access to services and transit. Part of what staff may be looking toward with the new housing element policies is the review of the PTOD regulations and other areas of the zoning code. Staff will determine if opportunities exist to prescribe maximum unit sizes, minimum densities, and further parking reductions. ${ }^{159}$ These changes would help to ensure that the PTOD regulations result in the desired outcomes of increasing the variety of housing types and supporting public transit.

The largest site in the vicinity of the California Avenue station area is currently occupied by Fry's Electronics, a large electronics retailer. The Fry's site has historically been a job and revenue center for the city: first, as a packing plant (Bayside Cannery), then a soft drink bottling plant, a Maximart supermarket, and most recently Fry's Electronics. ${ }^{160}$ The Fry's site will eventually play a major role in how the city plans for its future housing growth.

The Fry's site is currently zoned for multifamily residential, despite the historical commercial and retail use of the property. While the Fry's site is not being counted toward the housing numbers this cycle, it will likely play an important role in future cycles. ${ }^{161}$ The current housing element cycle goes through 2014. Fry's has a lease on the site until 2014, and the lease is extendable to 2019. It is their choice to stay or go, so the city does not know if and when they are going to move. Fry's has stated they do not intend on doing anything before 2014; but from the property owner's standpoint, he or she would probably prefer to turn it over to residential or mixed-use. ${ }^{162}$ It is important for the city to have regulations in place to ensure a smooth and orderly transition of this important area.

\footnotetext{
${ }^{158}$ Curtis Williams, interview by author, Palo Alto, CA, September 27, 2010.

${ }^{159}$ Ibid.

${ }^{160}$ Winslow, Palo Alto, 159.

${ }^{161}$ Williams, interview by author.

${ }^{162}$ Ibid.
} 


\section{Regional Housing Needs Assessment (RHNA)}

Each jurisdiction in California must update its housing element every seven years in order to be certified by the state. The main underlying goal of the housing element is to plan for the requirements of the RHNA, which is a jurisdiction's fair share or allocation of the housing needs for the region. ${ }^{163}$ The main causes of population change are the economy and whether or not companies are hiring. Overall, the trend in California is toward growth, and it will continue to grow regardless of the current economic downturn. As Roland Rivera said, it is just such a great place to live and offers such a diverse choice of employment opportunities. ${ }^{164}$ As a result, planning for this continued growth has taken a high level of importance in the Bay Area region.

The California Department of Housing and Community Development (HCD) uses a formula to come up with the housing unit allocation or quotas to assign to each COG to keep up with demand in the state. Then each COG formulates its own individual methodology, based on local conditions and criteria, to allocate the housing units to each local jurisdiction within its region. Local jurisdictions then decide how to plan for the anticipated growth.

ABAG is the COG for the nine-county San Francisco Bay Area. As such, it sets the number of housing units that must be planned for if the City of Palo Alto (and other jurisdictions) is going to meet its share of the projected population increase in the state of California. ABAG and other COGs use a formula to determine how to allocate the housing units (supply) in such a way as to meet the population increase (demand) in California. Some of the criteria the units allocated are based on include transit availability, existing employment, and future employment projections. ${ }^{165}$ These criteria identify Palo Alto as an excellent location for future residential growth.

For this seven-year cycle (which runs January 1, 2007 through December 31, 2013), Palo Alto was allocated 2,860 units by ABAG. A unit is considered to be affordable if it is below 120 percent of the area median income. About 1,900 of those units are for people making below 120 percent of the area median income. ${ }^{166}$ This is a relatively high number of units because of Palo Alto's high concentration of jobs.

There are four different income categories in which individuals are classified for the RHNA. They include (1) very low income, (2) low income, (3) moderate income, and

(4) above moderate income. ${ }^{167}$ The exact dollar amounts for each category are specific to each jurisdiction and are updated every cycle. When jurisdictions calculate how many units they have provided toward meeting their fair share of the housing unit allocation, there is no distinction made by the age of the owner. It is entirely based on the individual's income level and in which of the four income categories they are

\footnotetext{
${ }^{163}$ Babiera, interview by author.

${ }^{164}$ Roland Rivera, interview by author, Palo Alto, CA, August 31, 2010.

${ }^{165}$ Ibid.

${ }^{166}$ Babiera, interview by author.

${ }^{167}$ Ibid.
} 
classified. ${ }^{168}$ It is important for the city to plan for a variety of housing types to accommodate individuals from a variety of income levels.

The requirement is not to build the units during the cycle, but to plan for the development of those units. So there is a distinction between building the units and planning for the units. If the city has enough land that is zoned appropriately to accommodate the 2,860 units, then they do not need to rezone. On the other hand, if a municipality does not have enough land zoned to accommodate the allocated units, then they would need to initiate a rezoning process to provide the difference. The city must account for a specific number of units within each of the four income categories. ${ }^{169}$ By showing that they have zoning in place to accommodate the units, the city is making progress toward their eventual construction.

In the current RHNA cycle, Palo Alto has been allocated 2,860 units, and in the past the City Council has identified areas near transit as being appropriate areas for intensification of land use. It is anticipated that the Palo Alto City Council will direct staff to identify transit-oriented areas appropriate for growth even more in this cycle than in the past. ${ }^{170}$ Therefore, in the current draft of the housing inventory, staff has identified a large number of residential units within mixed-use zoning districts because of the City Council's directions: Development should be near fixed rail, may not result in the loss of commercial square footage, and must preserve single-family residential neighborhoods. ${ }^{171}$ As a result of these past directions, staff has been looking at the University Avenue area, the California Avenue area, and the El Camino Real corridor as these areas hold the greatest potential for transit-oriented development.

City staff has identified about 2,820 housing units, which are primarily located in the City Council specified areas. The only exceptions are the several projects that were already built away from transit such as, Vantage, Echelon, and Arbor Real. ${ }^{172}$ These units were counted toward the current allocation even though they were entitled prior to the beginning of the current RHNA cycle. This is because the units are allocated based on the year when the building permit is issued to begin construction, as opposed to when the entitlement is granted. City staff has not looked specifically at the California Avenue area yet because there is a concept plan being drawn up concurrently, and staff does not want to get ahead of that. They will wait for the California Avenue Concept Plan to identify the sites and how many units are going to be included to meet this cycle's 2,860 unit allocation. $^{173}$

Staff conducted a preliminary analysis looking at the existing zoning designations and the density of the existing uses. Under these criteria, if California Avenue were built out, it could accommodate a range of approximately 600-900 residential units in the

\footnotetext{
${ }^{168}$ Ibid.

${ }^{169}$ Ibid.

${ }^{170}$ Williams, interview by author.

${ }^{171}$ Rivera, interview by author.

${ }^{172}$ Ibid.

${ }^{173}$ Babiera, interview by author.
} 
area. ${ }^{174}$ This is far below the allowed maximum density per acre under the PTOD regulations (50 du/ac including density bonus). Staff made their estimate by reviewing what existed in the area and by looking at the allowed uses. Therefore, this is a moderate estimate and could be much higher under different circumstances.

California Avenue and University Avenue both have good potential for redevelopment because of their close proximity to transit and the variety of people from various income levels who work there. ${ }^{175}$ Ultimately it is up to the City Council to provide guidance on where any changes are going to be made to the housing element. The main purpose of the RHNA is to ensure that housing stock for all income levels is provided within each jurisdiction in order to move toward a more equal job-to-housing ratio. ${ }^{176} \mathrm{~A}$ balanced job-to-housing ratio is desirable as it leads to reduce VMT and, as a result, reduced GHG emissions.

\section{Job-to-Housing Balance}

Palo Alto is considered a job-rich city, with about three jobs to each housing unit. This is significant to acknowledge as cities that have more jobs usually have more people who commute to work, and, as a result, generate more GHGs. This is especially true of more affluent job-rich cities such as Palo Alto. While Palo Alto is classified as job rich, regional center San Jose is considered housing rich as are many affluent neighboring cities such as Los Gatos. ${ }^{177}$ Many job-rich cities also have elevated housing prices as it is generally desirable to have a shorter commute.

However, there are benefits to having a concentration of jobs. For example, Palo Alto is an employment center; from a transit point of view, all those jobs help to support the city's transit stations. ${ }^{178}$ In that regard, spreading out the jobs would not make sense. Palo Alto has fixed rail transit stations so it makes the city a more suitable location for having a larger number of jobs. While it may make sense for Palo Alto to have a more balanced job-to-housing ratio, it may not for other neighboring communities such as Los Gatos, Los Altos, or Portola Valley. Those cities do not possess the ideal characteristics to accommodate high job growth due to extremely high housing prices and because they are not particularly well served by transit.

In jurisdictions that are well served by mass transit, it should be a priority to encourage a more balanced job-to-housing ratio. If Los Gatos and other traditionally residential communities are required to add jobs, the result will be an increase in VMT and resulting GHG emissions. This is because a very small percentage of the people who work in Los Gatos would actually be able to afford to live there. ${ }^{179}$ San Jose should have

\footnotetext{
${ }^{174}$ Ibid.

${ }^{175}$ Ibid.

${ }^{176}$ Rivera, interview by author.

${ }^{177}$ Ibid.

${ }^{178}$ Williams, interview by author.

${ }^{179}$ Rivera, interview by author.
} 
a more balanced ratio, and, in particular, they should continue to enhance their policies and programs to create more jobs, because they have such a large housing stock. Anywhere with access to mass transit should aim for being closer to a one-to-one balanced ratio. ${ }^{180}$ In addition to lowering VMT, this will ensure that future transit infrastructure is most efficiently planned.

Through the RHNA's methodologies and the allocation of housing units to jurisdictions within their region, COGs are able to influence the job-to-housing balance. Generally, the COG tries to work toward a more balanced job-to-housing ratio. This typically results in Palo Alto being allocated a relatively high number of housing units. ${ }^{181}$ The whole process is still fairly new, as this is only the 4th RHNA cycle since it was introduced and each cycle has a slightly different methodology. But generally, the methodology seems to be moving in this direction.

In the past, the RHNA mainly sought to identify where the jobs were located and where the housing was located within a region. Then its scope was expanded to include putting more housing near where the jobs were located and more jobs where the housing was located. Over the following RHNA cycles, the methodologies employed by many COGs in general, and the MTC more specifically (in Palo Alto's case), have evolved to consider a wider variety of criteria such as the location of jobs, housing, services, and mass transit. ${ }^{182}$ It is important for the city to recognize and plan for these changing criteria so they can most effectively plan for future growth.

Palo Alto currently has a high number of jobs, excellent services, and is well served by mass transit access, which means that based on ABAG's methodology, it is allocated a high number of housing units. In this RHNA cycle, the methodology resulted in jurisdictions that have a high number of existing jobs, fixed rail transit stations, and services, receiving a higher number of housing units in the RHNA. ${ }^{183}$ One of the goals of the RHNA is to balance out the regional job-to-housing ratio. However, a balanced jobto-housing ratio may make more or less sense from one community to the next.

Nevertheless, most cities are moving in the general direction of a more balanced ratio.

\section{Priority Development Areas (PDAs)}

The ABAG Focus initiative is a regional program for planning growth that was created approximately five years ago. One of the main components of the Focus initiative is the identification of Priority Development Areas within the region. PDAs are focused development areas that are usually about 100 acres in size. Cities were required to submit an application to ABAG in order to designate an area within their boundaries as a PDA. Palo Alto applied to ABAG for California Avenue to be a PDA because it is near transit, there are services there, and the Stanford Research Park and employment center is across

\footnotetext{
${ }^{180}$ Ibid.

${ }^{181}$ Ibid.

${ }^{182}$ Ibid.

${ }^{183}$ Ibid.
} 
the street (El Camino Real). ${ }^{184}$ Based on those criteria, the California Avenue area is an ideal area to focus federal and state grant money in order to create a vibrant, mixed-use area.

In the past, in order to get state and federal grants and aid, jurisdictions would accumulate points based on criteria such as the possession of a certified housing element. These points would act as bonuses when applying for state and federal grants and aid. Currently cities still receive points for having a certified housing element; but now the application also asks the question, Is this particular project going to be located in a $P D A{ }^{185}$ If it is, then the project receives additional bonus points. This is important to understand because grants can help to upgrade pubic infrastructure and to make an area attractive for developers.

The California Avenue PDA has primarily the same boundary as the California Avenue PTOD district, with the main difference being that the Fry's site is not currently included within the PTOD boundary (see Appendix 1 for a copy of the PTOD district boundary map). ${ }^{186}$ Part of the reason Palo Alto was so interested in the PDA program was because the city already had the California Avenue PTOD zoning in place. On the application to designate a PDA, there was a question: Is zoning in place for intensification of land uses ${ }^{187}$ In Palo Alto's case, the answer was yes, we have the PTOD regulations in place. The presence of existing TOD regulations was one of the criteria that was looked upon favorably. Another criterion that was looked favorably upon was the California Avenue PDA's proximity to the VTA 522 Bus Rapid Transit (BRT) stop. With a BRT line and the two Caltrain stations in Palo Alto, the city was identified as being an ideal location to concentrate additional housing and growth.

\subsection{California Avenue Concept Plan}

City staff are currently working on a California Avenue Concept Plan project as a part of the comprehensive plan update. One of the ultimate goals of the plan is to determine if there is enough support to allow staff to recommend changing the overlay part of the PTOD zoning to allow it by right. ${ }^{188}$ This would streamline the process by requiring property owners to go only to the Architectural Review Board for design review. Under the current regulations, the process includes a rezoning which must be approved by the City Council and then a separate Major Architectural Review Board process for the actual building design.

The boundary of the California Avenue Concept Plan is roughly the same as that of the PTOD district. However, the concept plan area also includes the Fry's site. Within the California Avenue Concept Plan, staff is focusing on three subareas. The three

\footnotetext{
${ }^{184}$ Rivera, interview by author.

${ }^{185}$ Ibid.

${ }^{186}$ Ibid.

${ }^{187}$ Ibid.

${ }^{188}$ Williams, interview by author.
} 
subareas were identified based on community feedback and include (1) the California Avenue business area itself, (2) the Park Boulevard area, and (3) the Fry’s site. ${ }^{189}$

One of the big questions staff is evaluating with the California Avenue Concept Plan is, Should the Fry's site be kept commercial ${ }^{190}$ This would be in line with the general directive from City Council to retain existing commercial square footage. However, in the case of the Fry's site, it may not be an ideal commercial site as it does not have direct access to major freeways or frontage on El Camino Real. People do not usually go to Fry's unless they already know it is there, because they cannot see it when they drive by. Also, there is additional competition from Best Buy (another electronics retailer recently built in East Palo Alto just off Highway 101) so it may not be the best commercial site. Staff will be looking at what might happen if it is redeveloped with a mixed-use or residential form.

The zoning and comprehensive plan land-use designation for the site is currently multifamily residential. Staff are studying questions such as, What do we want to do with the site? Do we want the use to revert to the underlying multifamily residential zoning? Do we want it to stay as a commercial use with the potential to generate revenue into the future ${ }^{191}$ Those questions will ultimately be decided by the City Council.

While the California Avenue Concept Plan—and Fry's site, more specificallyrepresent great locations to direct growth within the city, it brings up the question, Should development be intensified in the California Avenue area? The current comprehensive plan referenced the California Avenue / Ventura Avenue area for some intensification because of its commercial orientation and proximity to transit. However, it does not give a clear picture of how much intensification may be appropriate. The question has become, How are we handling the transition which is occurring in this area ${ }^{192}$ Also, public perceptions have been changing over time, so plans must be updated.

The City Council directed staff to prepare the California Avenue Concept Plan to provide additional guidance, within the comprehensive plan, with respect to development in the area. The concept plan will help to address the transition occurring in the area and revisit current policies and programs. Staff is not proposing zoning changes as a part of the concept plan, but staff is trying to answer the question, What do we want for this particular area for the next comprehensive plan cycle ${ }^{193}$ It is important to ensure that the surrounding community is involved in the decision-making process.

As a part of the California Avenue Concept Plan, staff held separate meetings with three stakeholder groups including the local neighborhood associations, the California Avenue Business Owners Association, and the property owner of the Fry's site. Staff also held three larger communitywide workshops that included representatives

\footnotetext{
${ }^{189}$ Elena Lee, interview by author, Palo Alto, CA, September 9, 2010.

${ }^{190}$ Williams, interview by author.

${ }^{191}$ Lee, interview by author.

${ }^{192}$ Ibid.

${ }^{193}$ Ibid.
} 
from these three groups. Staff and consultants gathered input at those meetings and came up with three alternatives for each of the three subareas. ${ }^{194}$

The California Avenue Concept Plan will make recommendations on which alternatives should be adopted. The Planning and Transportation Commission (PTC) and City Council will then select and adopt an alternative, which will then be included in the larger comprehensive plan update process. Environmental and technical studies, as well as any changes in land use that are proposed, will be officially adopted as part of the comprehensive plan process. ${ }^{195}$ The concept plan will also serve to provide a preview of the area before staff gets too far along in the comprehensive plan update process. ${ }^{196}$ It is important to understand the changing demographics in the area to properly plan for growth.

The California Avenue Concept Plan will help to answer the overall question, What will the city's approach to housing be in the future? It will also provide guidance on the city's overall approach to housing. All of these different aspects are being discussed at the same time. ${ }^{197}$ Generally, the direction has been to not radically deviate from the existing land-use designations. The intent has been to determine what is there now, to find out how the community feels about it, and what makes sense as far as development.

The three general alternatives staff is considering include (1) leaving things as they are, (2) mixed use with medium density, (3) mixed use with medium to high density. At this point in the process, staff is just looking at building envelopes, building massing, but not specific density numbers. ${ }^{198}$ For example, under the scenarios above, alternative (2) would represent two- to three-story buildings, and alternative (3) would represent three- to four-story buildings. The existing form along much of the corridor is one- to two-story buildings, so these scenarios represent as much as a 100 percent increase in density over the existing development. California Avenue's current auto-orientated streetscape is evident in Figure 7.

\footnotetext{
${ }^{194}$ Ibid.

${ }^{195}$ Ibid.

${ }^{196}$ Ibid.

${ }^{197}$ Ibid.

${ }^{198}$ Ibid.
} 


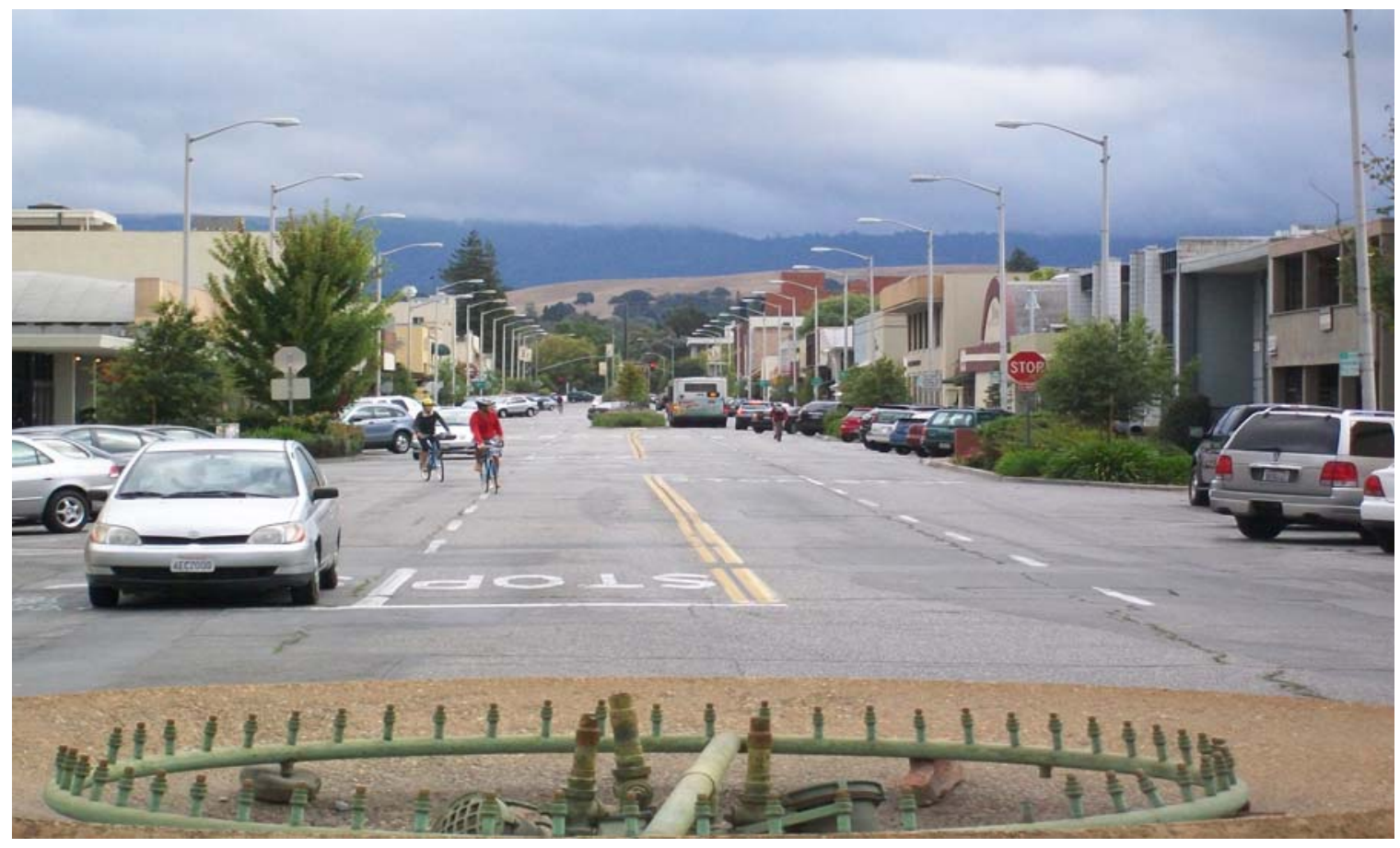

Figure 7: View looking down California Avenue from the Caltrain station toward El Camino Real. Photograph by author.

The current comprehensive plan also identifies the California Avenue / Ventura Avenue mixed-use area adjacent to the California Avenue business district. This area is also served by the California Avenue Multimodal Transit Station. The California Avenue / Ventura Avenue area also offers exceptional opportunities for new transit-oriented development, as it includes several underutilized properties likely to be redeveloped in the near future. New housing in this area could provide the momentum for new pedestrian amenities and shuttle bus connections to nearby Stanford Research Park. ${ }^{199}$ It is important to plan for this growth in advance so that it does not occur in a haphazard and inefficient manner.

It is very likely that California Avenue's close proximity to the Stanford Research Park will continue to lead to increased development pressure in the area. The Stanford Research Park contains many prominent technology companies. It is anticipated that the Stanford Research Park frontage along El Camino Real will be redeveloped to reinforce the important connection between the research park, the California Avenue business district, and the California Avenue transit station. ${ }^{200}$ The California Avenue area should be planned and developed with complementary uses and at an intensity of use which respects the extremely close proximity to this regional job center.

${ }^{199}$ City of Palo Alto, Enhancing the New Century, L-26.
${ }^{200}$ Ibid., L-35. 


\subsection{Zoning Ordinance Update: History of PTOD Regulations}

\section{Zoning Ordinance Update (ZOU)}

The PTOD regulations were originally developed and implemented as a result of the Zoning Ordinance Update (ZOU) program. The ZOU was a program initiated by the City of Palo Alto in 2000 to review and update the entire zoning ordinance. The current Director of the City of Palo Alto's Planning and Community Environment Department, Curtis Williams, was involved with the ZOU from 2000 until 2006 when he was hired on as a full-time staff member. ${ }^{201}$ In addition to city staff, many consultants worked on the ZOU to develop regulations for higher-intensity uses and to integrate (into the zoning ordinance) the latest comprehensive plan directives which included higher-intensity residential, with a pedestrian- and bicycle-oriented environment, and a focus on creating services. ${ }^{202}$ Cities must continually work to ensure their zoning ordinance and comprehensive plan are consistent.

Staff started by reviewing and analyzing the existing zoning ordinance. What staff found was the zoning for the downtown area already allowed relatively high-intensity residential and commercial development. Therefore, there was not a pressing need to make changes there; and there is a 50 -foot height limit in the downtown area. ${ }^{203} \mathrm{In}$ addition, the city already had a pretty good tax basis for downtown; but California Avenue, on the other hand, appeared to be underdeveloped and underzoned in that respect. ${ }^{204}$ Therefore, it was identified as a good candidate for growth.

At the time, many of the properties in the immediate vicinity of California Avenue were zoned commercially, which allowed some residential, but only as part of mixed-use development. Other areas of California Avenue had a variety of uses including industrial and office uses, but did not allow for residential uses at all. ${ }^{205}$ The PTOD regulations served as the means to implement the comprehensive plan policies and programs that specifically talk about developing transit-oriented development regulations for the area around California Avenue and University Avenue ${ }^{206}$ As early as 2000, the area was increasingly being identified as a suitable area for transit-oriented development.

The local political climate at the time may have also had a detrimental effect on the creation of the PTOD regulations. Several large residential projects had been approved around the time of the ZOU and formulation of the PTOD regulations. These projects led to a growing community sentiment that too many multifamily residential projects were being approved. The residential market in Palo Alto and nationwide was

\footnotetext{
${ }^{201}$ Williams, interview by author.

${ }^{202}$ Ibid.

${ }^{203}$ Ibid.

${ }^{204}$ Ibid.

${ }^{205}$ Ibid.

${ }^{206}$ Ibid.
} 
skyrocketing at the time. ${ }^{207}$ In addition, some of the proposed multifamily residential development was not in ideal locations.

The city was receiving applications for projects that were located on land that was further out from the central city or downtown (University Avenue) area. These applications involved the redevelopment of land that had been zoned industrial, light industrial, and research park, to multifamily residential and they were usually not very close to transit stations, but near Highway $101 .{ }^{208}$ As a result, the city wanted to try to focus the location of development and, specifically, multifamily residential back to areas that had good access to transit and to goods and services. That was the fundamental concept behind the comprehensive plan update and $\mathrm{ZOU}^{209}$ It is important to understand the dynamics that were in effect at the time when the PTOD regulations were originally implemented.

\section{History of PTOD Combining District Regulations}

The PTOD regulations were based on a directive from the comprehensive plan policies and programs that specifically talk about developing Transit-Oriented Residential regulations for the area around California Avenue and University Avenue. "Transit-Oriented Residential allows higher-density residential dwellings in the University Avenue / downtown and California Avenue commercial centers within a walkable distance, approximately 2,000 feet, of the city's two multimodal transit stations. The land-use category is intended to generate residential densities that support substantial use of public transportation and especially the use of Caltrain."210 The PTOD regulations served the purpose of codifying the comprehensive plan policies into the zoning code.

The city was doing a complete Zoning Ordinance Update (ZOU) at the time and staff were working through the various chapters of the zoning ordinance of the municipal code. Part of the effort involved developing the new PTOD regulations and incorporating them into the city's zoning ordinance. The city would then have codified regulations and development standards that promoted higher-density, transit-oriented development. ${ }^{211}$

Design standards, known as the Context-Based Design Criteria, were included in the PTOD district regulations to ensure redevelopment in the area was inclusive of the existing streetscape. ${ }^{212}$ The PTOD development standards were purposely crafted to be fairly open with the intent that the PTC would have more flexibility in making project specific recommendations which the City Council could then adopt. ${ }^{213}$ The goal was to ensure that site-specific conditions and constraints would be respected by the development.

\footnotetext{
${ }^{207}$ Ibid.

${ }^{208}$ Ibid.

${ }^{209}$ Ibid.

${ }^{210}$ City of Palo Alto, Enhancing the New Century, L-13.

${ }^{211}$ Clare Campbell, interview by author, Palo Alto, CA, August 31, 2010.

${ }^{212}$ City of Palo Alto, Enhancing the New Century, L-13.

${ }^{213}$ Lee, interview by author.
} 
Staff created the PTOD regulations as an overlay district, so property owners could choose whether to develop more residential than could otherwise be built using the development standards contained in the underlying zoning district. ${ }^{214}$ Before the late 1990s, it was really difficult to get people to build housing in Palo Alto. That is one of the reasons the PTOD regulations were so focused on promoting additional residential. ${ }^{215}$ However, from 2000 to 2006, politically it was becoming difficult because several large multifamily residential projects were proposed to go through and there was concern that California Avenue's distinct character might change too quickly. ${ }^{216}$

Due to these circumstances, instead of making the PTOD regulations by right, they become an overlay or combining district that had to be applied for through a rezoning process. This decision was partly reached through discussions with property owners (mainly nonresidential uses) who said they did not want to be rezoned to residential, even despite the fact that they were not being required to make any changes at the time. ${ }^{217}$ By making the PTOD regulations an overlay, property owners could retain the choice to keep the underlying zoning designation and uses, as they had always been, or request the PTOD zoning through a rezoning process. In this way, the request for rezoning would still be heard by the Planning and Transportation Commission and the City Council so there would still be an opportunity for public input and control.

The PTOD regulations state if a parcel is more than one acre it must have two housing types; if it is more than two acres, it must have three housing types. ${ }^{218}$ The housing types that are referred to in the beginning of the PTOD regulations are really intended to be smaller attached units, or single-family, or townhomes - projects with zero lot lines. It is really those housing types that the PTOD regulations are meant to encourage as opposed to BMR units. This is because the city already has requirements for BMR units. Also, in the PTOD regulations, there are some bonuses for density, floor area ratio (FAR), and maximum height, if a property owner proposes to build more BMR units than he or she would otherwise be required to provide. ${ }^{219}$

The PTOD regulations have the standard parking requirements (contained in Chapter 18.52), which are based on use categories, with more parking-intense uses requiring more parking spaces. The allowed parking adjustments described in Chapter 18.52 apply to projects that use the PTOD regulations, but are applied at the Planning Department Director's discretion. Also, there are several additional parking allowances unique to the PTOD regulations. ${ }^{220}$ These parking regulations are important to ensure that the resulting development is truly transit-oriented.

Not all of staffs' recommendations for the PTOD regulations were enacted by the decision makers. For example, staff wanted to include minimum-density requirements in

\footnotetext{
${ }^{214}$ Williams, interview by author.

${ }^{215}$ Ibid.

${ }^{216}$ Ibid.

${ }^{217}$ Ibid.

${ }^{218}$ Ibid.

${ }^{219}$ Ibid.

${ }^{220}$ Lee, interview by author.
} 
the PTOD regulations. Staff did not end up including minimum-density requirements, at the direction of the decision makers, who were concerned about potential public objection. It was the PTC that really had the most to do with not including a minimum density in the PTOD regulations. ${ }^{221}$ This one omission may have had the greatest negative impact on the success of the PTOD regulations.

Originally, the PTOD boundary was proposed to extend all of the way around to capture the Fry's site. This boundary was based on the widely accepted idea that people are generally willing to walk up to 2,000 feet to reach a major fixed rail transit station. In addition, the Fry's site was going to revert back to multifamily residential zoning. However, there was opposition from the owners of the Fry's site who wanted to preserve it as a commercial use. The ultimate result was that the Fry's site was removed from the PTOD district to appease the site's owners and relieve some of the perceived pressure to redevelop the site.

Another result was that instead of the nonconforming commercial use ending with the stated expiration date, it was extended by the city. ${ }^{222}$ The city recognized the substantial sales tax revenue that the business generated. As a result of these circumstances, the City Council directed staff to remove the Fry's site from the PTOD boundary area and, as a result, it is still zoned multifamily residential. ${ }^{223}$ The City Council also directed staff to study if there was a way to retain Fry's, and if not Fry's, a way to keep the same amount of retail or commercial on the site. ${ }^{224}$

Also, around this time, the homeowners' association representative for the 101 California Avenue property (a large, mixed-use development that abuts the California Avenue train station) was not very supportive of the new PTOD regulations. He expressed concerns that additional housing would not necessarily result in increased ridership, and disagreed with many of the underlying planning theories and concepts concerning TOD in general. These same theories and concepts are understood and supported by planning experts and are frequently used to justify TOD. In addition, existing residents in the area were very concerned about parking overflow into their neighborhoods, as the PTOD regulations do allow for a reduction in required parking. ${ }^{225}$

Overall, with the advent of the PTOD regulations, staff was trying to encourage a variety of housing options, while also reducing vehicle use by introducing opportunities to reduce required parking, even for commercial uses. ${ }^{226}$ This process took place over two years, and included multiple community meetings which ensured that the community had opportunities to provide input. While the PTOD regulations may end up helping the city toward meeting its RHNA, it was not the primary goal. ${ }^{227}$ This is a particularly

\footnotetext{
${ }^{221}$ Campbell, interview by author.

${ }^{222}$ Ibid.

${ }^{223}$ Williams, interview by author.

${ }^{224}$ Ibid.

${ }^{225}$ Ibid.

${ }^{226}$ Ibid.

${ }^{227}$ Ibid.
} 
interesting fact, as it now appears that the area is increasingly being identified as a promising location for future housing growth.

Staff had meetings with the California Avenue Business Owners Association, which represents business interests in the California Avenue area. Some of the members of the business group were a little unsure, but generally they were supportive. ${ }^{228}$ They did have some concerns about traffic, but they understood that more people in the area equals more business.

At the time, residents' general perceptions were that the downtown University Avenue area was getting the most attention from developers, and redevelopment projects were being initiated there. While there was community sentiment against changing the zoning of the California Avenue area, there were community residents who recognized the PTOD regulations as an opportunity for the California Avenue area. There were people on both sides of the issue. Some did not want traffic, but did want all of the amenities that are required by the PTOD regulations and Context-Based Design Criteria (which were also being developed concurrently with the ZOU). ${ }^{229}$

The PTOD regulations are also intended to enhance the pedestrian and bicyclist experience along Park Boulevard (a nearby city-designated Bicycle Boulevard). ${ }^{230}$ This was one of the probable benefits of TOD that was identified at the time and used to educate city staff and the public on why TOD was a good thing that Palo Alto should pursue. With this and other efforts, the city consciously tried to use technical studies to educate the public on why establishing a TOD district within the city would be a good idea. ${ }^{231}$ It was important that the city educate the community on the potential costs and benefits of the revised zoning to secure their support.

The PTOD regulations were based on the best practices in TOD at the time. City staff tried to take the PTOD regulations even further, but the PTC was not comfortable with going too far, given the political climate at the time. Some of the recommendations that were ultimately dropped included minimum residential densities and maximum allowable parking limits. There were numerous revisions and drafts of the PTOD regulations. ${ }^{232}$ It is important to note that many of the more aggressive TOD components that were identified and proposed by staff were taken out because the decision makers did not feel comfortable with them at the time.

Providing a variety of housing types and, specifically, smaller units seems to be against the wishes of many current residents of the city. This is presumably because many people are opposed to changes that they perceive as being harmful to the neighborhood character and value of their property. It is also important to understand the development climate at the time within the city. Around the time of the PTOD

\footnotetext{
${ }^{228}$ Ibid.

${ }^{229}$ Ibid.

${ }^{230}$ Ibid.

${ }^{231}$ Ibid.

${ }^{232}$ Ibid.
} 
regulations, the city processed applications for the rezoning of the Palo Alto Bowl (bowling alley) site, Summer Winds Nursery, and the Fry's site. As a result, these three sites were zoned for multifamily residential, but had nonconforming commercial uses. The market for housing was skyrocketing at the time and residents were worried about the potential impacts (to schools, parks, and libraries) of too many multifamily residential units being built. ${ }^{233}$

City staff were instructed to revise the zoning ordinance, to ensure additional applications would not be submitted to turn commercial and industrial sites into multifamily residential. Developers at the time were interested in big multifamily residential developments. It was also around this time that there was a big shift in direction from the PTC and City Council. They shared the concern of many city residents: that residential development was running rampant in the city. This public perception shift against new multifamily residential development in the city was at the same time the city effort to prepare the PTOD regulations was almost complete. This ultimately resulted in staff being directed to make the regulations an overlay, as opposed to by right, and many of the most aggressive standards were removed. ${ }^{234}$

\subsection{Review of Chapters 18.34 (PTOD) and 18.52 (Parking)}

The PTOD regulations in their approved and codified format are contained in PAMC Chapter 18.34. There is also supplemental information about parking requirements and adjustments in PAMC Chapter 18.52. It is important to review these municipal code sections carefully to ensure that the requirements are understood. Chapter 18.34 of the PAMC codifies the goals and intent of the PTOD combining district into tangible guidelines through the use of zoning. More specifically, permitted and conditionally permitted uses, development standards, and parking requirements are described.

\section{Chapter 18.34 (PTOD)}

The PTOD regulations prescribe allowable land uses and development standards with which new development in the district must comply. The maximum allowable density of residential uses is expressed in terms of dwelling units per acre (du/ac). In nonresidential areas, the maximum intensity of use is expressed through floor area ratios (FAR). The FAR is the ratio of building area to lot area on a site. For example, if the lot area of a site is 5,000 square feet and the FAR is .5, then a maximum of 2,500 square feet can be built on the lot.

Table 1 contains the permitted (P) and conditionally permitted (CUP) land uses and development standards (respectively) for the California Avenue PTOD district. As Table 1 shows, multiple-family residential housing, mixed-use development, where

\footnotetext{
${ }^{233}$ Ibid.

${ }^{234}$ Ibid.
} 
residential and nonresidential uses are combined, and hotels are the only permitted uses in the PTOD district. Live/work units are conditionally permitted (subject to the issuance of a conditional use permit [CUP]).

Table 1: Permitted and Conditionally Permitted Land Uses - California Avenue

\begin{tabular}{|c|c|c|}
\hline Land Uses & $\begin{array}{c}\text { PTOD } \\
\text { California Avenue }\end{array}$ & $\begin{array}{c}\text { PTOD } \\
\text { University Avenue [Reserved] }\end{array}$ \\
\hline Multiplefamily residential housing & $\mathrm{P}$ & \\
\hline $\begin{array}{l}\text { Mixed-use development, where } \\
\text { residential and non-residential uses are } \\
\text { combined }\end{array}$ & $\begin{array}{c}\mathrm{P} \\
\text { See Section 18.34.030(b) below for } \\
\text { specific uses }\end{array}$ & \\
\hline Live/Work Units & $\begin{array}{c}\text { CUP } \\
\text { Subject to limitations of Section } \\
18.34 .040(\mathrm{~b})\end{array}$ & \\
\hline Hotel & $\begin{array}{c}\mathrm{P} \\
\text { Subject to limitations of Section } \\
18.34 .040 \text { (c) }\end{array}$ & \\
\hline $\mathrm{P}=$ Permitted Use & CUP $=$ Conc & nal Use, Use Permit Required \\
\hline
\end{tabular}

Source: City of Palo Alto, Title 18.34 of the Palo Alto Municipal Code: Zoning Ordinance, (2006), 2.

Table 2 contains the development standards for the California Avenue PTOD district. Table 2 shows, among other development standards, that the maximum residential density in the PTOD district is 40 dwelling units to the acre. Also, there are a variety of maximum floor area ratios that may be used, depending on the proposed use. For example, a 100 percent residential project has a maximum floor area ratio of one to one, a mixed-use project has a maximum floor area ratio of one and one quarter to one, and a hotel use has a maximum floor area ratio of two to one. This information shows that the highest floor area may be obtained through the development of a hotel project in the PTOD district. 
Table 2: Development Standards for the California Avenue PTOD District

\begin{tabular}{|c|c|c|}
\hline Standards $^{1}$ & PTOD - California Avenue & PTOD - Downtown [Reserved] \\
\hline Max. Dwelling Units: & $40 \mathrm{DU}^{2} \mathrm{AC}{ }^{2}$ & \\
\hline \multicolumn{3}{|l|}{ Max. FAR: } \\
\hline $100 \%$ Residential FAR & $1.0: 1^{2}$ & \\
\hline Mixed Use FAR & $1.25: 1^{2,3}$ & \\
\hline Mixed Use Non-Residential FAR Cap & $\begin{array}{c}\text { Total: } 0.35{ }^{4} \\
\text { Office and research and } \\
\text { development uses: } 0.25 \mathrm{FAR}\end{array}$ & \\
\hline Hotels & 2.0 & \\
\hline Height: & 40 feet ${ }^{2}$ & \\
\hline \multicolumn{3}{|l|}{ Open Space: } \\
\hline Minimum area required & $\begin{array}{l}5 \text { or fewer units: } 200 \text { s.f. per unit } \\
6 \text { or more units: } 100 \text { s.f. per unit }\end{array}$ & \\
\hline Minimum dimensions & $\begin{array}{l}\text { Private open space: } 6 \text { feet } \\
\text { Common open space: } 12 \text { feet }\end{array}$ & \\
\hline Standards $^{1}$ & PTOD - California Avenue & PTOD - Downtown [Reserved] \\
\hline Parking: & $\begin{array}{l}\text { Rates established by use, } \\
\text { per Chs. } 18.52 \text { and } 18.54\end{array}$ & \\
\hline Parking Adjustments: & See Section 18.34 .040 (d) & \\
\hline \multicolumn{3}{|c|}{ Setbacks and daylight plane requirements for properties adjacent to R-1 and R-2 zones: } \\
\hline Setbacks & $\begin{array}{l}\text { On portion of site that abuts: } \\
\text { 1. Interior side yard: } 6 \text { feet } \\
\text { 2. Rear yard: } 20 \text { feet }\end{array}$ & \\
\hline Daylight Plane & $\begin{array}{l}\text { On portion of site that abuts: } \\
\text { 1. Interior side yard: } \\
\text { a. Initial height at interior side lot } \\
\text { line: } 10 \text { feet } \\
\text { b. Angle (degrees): } 45 \\
\text { 2. Rear yard: } \\
\text { a. Initial height at rear setback line: } \\
16 \text { feet } \\
\text { b. Angle (degrees): } 45\end{array}$ & \\
\hline \multicolumn{3}{|c|}{ Setbacks and daylight and daylight plane requirements for properties adjacent to Caltrain Right-of-Way: } \\
\hline Setbacks & $\begin{array}{l}\text { On portion of site that abuts Caltrain right- } \\
\text { of-way. } 5 \text { feet (landscaped) }\end{array}$ & \\
\hline Daylight Plane & $\begin{array}{l}\text { On portion of site that abuts Caltrain right- } \\
\text { of-way: } \\
\text { a. Initial height at property line } \\
\text { w'Caltrain right-of-way: } 16 \text { feet } \\
\text { b. Angle (Degrees): } 45\end{array}$ & \\
\hline
\end{tabular}

Source: City of Palo Alto, Title 18.34 of the Palo Alto Municipal Code: Zoning Ordinance, (2006), 3, 4.

\section{Chapter 18.52 (Parking)}

The PTOD regulations refer to Chapter 18.52 (Parking) to determine the minimum amount of required parking spaces. Table 3 details the minimum number of vehicle and bicycle parking spaces that are required based on the use category and amount of floor area. As the table shows, certain pedestrian-oriented uses, such as personal services, have a much lower number of required parking spaces compared to other less desirable uses. There are also a certain number of required bicycle parking spaces based either on the number of employees or square footage of the use. 
Table 3: Minimum Off-Street Parking Requirements - California Avenue

\begin{tabular}{|c|c|c|c|}
\hline \multicolumn{4}{|c|}{ For California Avenue Parking Assessment District: } \\
\hline Automobile Service Stations & $\begin{array}{l}1 \text { per } 310 \text { square feet of } \\
\text { gross enclosed floor area, } \\
\text { plus queue capacity } \\
\text { equivalent to the service } \\
\text { capacity of gasoline pumps }\end{array}$ & $\begin{array}{l}1 \text { per } 10 \\
\text { employees }\end{array}$ & $100 \%-\mathrm{ST}$ \\
\hline Automotive Services & $\begin{array}{c}1 \text { per } 150 \text { square feet of gross } \\
\text { floor area, display, or storage } \\
\text { on site }\end{array}$ & $\begin{array}{l}1 \text { per } 10 \\
\text { employees }\end{array}$ & $100 \%-\mathrm{ST}$ \\
\hline \multicolumn{4}{|l|}{ Eating and Drinking Services: } \\
\hline (a) With drive-in or take-out facilities & $\begin{array}{c}3 \text { per } 100 \text { sf of gross floor } \\
\text { area }\end{array}$ & 3 per $400 \mathrm{sf}$ & $\begin{array}{l}40 \%-\mathrm{LT} \\
60 \%-\mathrm{ST}\end{array}$ \\
\hline (b) All others & $\begin{array}{c}1 \text { per } 155 \text { sf of gross floor } \\
\text { area }\end{array}$ & 1 per $1,550 \mathrm{sf}$ & \\
\hline \multicolumn{4}{|l|}{ Financial services: } \\
\hline $\begin{array}{l}\text { (a) Bank, savings and loan offices with } \\
7,500 \text { square feet of floor area or } \\
\text { less: }\end{array}$ & $\begin{array}{c}1 \text { per } 180 \text { sf of gross floor } \\
\text { area }\end{array}$ & $\begin{array}{c}1 \text { per } 1,800 \\
\text { sf }\end{array}$ & $\begin{array}{l}40 \%-\mathrm{LT} \\
60 \%-\mathrm{ST}\end{array}$ \\
\hline $\begin{array}{l}\text { (b) Banks, savings and loan offices with } \\
\text { more than } 7,500 \text { square feet of floor } \\
\text { area: }\end{array}$ & $\begin{array}{c}1 \text { per } 310 \text { sf of gross floor } \\
\text { area }\end{array}$ & & \\
\hline (c) Others & $\begin{array}{c}1 \text { per } 180 \text { sf of gross floor } \\
\text { area }\end{array}$ & $\begin{array}{c}1 \text { per } 1,800 \\
\text { sf }\end{array}$ & \\
\hline \multicolumn{4}{|l|}{ General Business Services: } \\
\hline (a) Enclosed & $\begin{array}{c}1 \text { per } 360 \text { sf of gross floor } \\
\text { area }\end{array}$ & 1 per $3,600 \mathrm{sf}$ & $\begin{array}{l}80 \%-\mathrm{LT} \\
20 \%-\mathrm{ST}\end{array}$ \\
\hline (b) Open lot & $\begin{array}{c}1 \text { per } 500 \text { sf of sales, display } \\
\text { or storage site area }\end{array}$ & $\begin{array}{c}1 \text { per } 5,000 \\
\text { sf }\end{array}$ & $100 \%-\mathrm{ST}$ \\
\hline $\begin{array}{l}\text { Medical, professional, and general } \\
\text { business offices }\end{array}$ & $\begin{array}{c}1 \text { per } 310 \text { sf of gross floor } \\
\text { area }\end{array}$ & $\begin{array}{c}1 \text { per } 3,100 \\
\text { sf }\end{array}$ & $\begin{array}{l}60 \%-\mathrm{LT} \\
40 \%-\mathrm{ST}\end{array}$ \\
\hline Personal Services & $\begin{array}{l}1 \text { per } 450 \text { sf of gross floor } \\
\text { area }\end{array}$ & $\begin{array}{c}1 \text { per } 4,500 \\
\text { sf }\end{array}$ & $\begin{array}{l}20 \%-\mathrm{LT} \\
80 \%-\mathrm{ST}\end{array}$ \\
\hline Use & Vehicle Parking & \multicolumn{2}{|c|}{$\begin{array}{l}\text { Bicycle Parking } \\
\text { Requirement }\end{array}$} \\
\hline & & Spaces & Class $^{1}$ \\
\hline \multicolumn{4}{|l|}{ Retail: } \\
\hline (a) Intensive & $\begin{array}{l}1 \text { per } 240 \text { sf of gross floor } \\
\text { area }\end{array}$ & 1 per $2,400 \mathrm{sf}$ & $\begin{array}{l}20 \%-\mathrm{LT} \\
80 \%-\mathrm{ST}\end{array}$ \\
\hline (b) Extensive & $\begin{array}{c}1 \text { per } 350 \text { sf of gross floor } \\
\text { area }\end{array}$ & 1 per $3,500 \mathrm{sf}$ & \\
\hline (c)Open lot & $\begin{array}{c}1 \text { for each } 500 \text { square feet of } \\
\text { sales, display, or storage site } \\
\text { area. }\end{array}$ & 1 per $5,000 \mathrm{sf}$ & $100 \%-\mathrm{ST}$ \\
\hline \multicolumn{4}{|l|}{ OTHER USES } \\
\hline Any use not specified & See 7 & able 1 & \\
\hline
\end{tabular}

Source: City of Palo Alto, Title 18.52 of the Palo Alto Municipal Code: Zoning Ordinance, (2006), 14. 
While the PTOD regulations employ the standard required parking tables that apply throughout the city, there are some additional parking adjustments which are unique to the PTOD district. After determining the minimum number of required parking spaces for a new development, an applicant may request a parking adjustment (at the Planning Department Director's discretion). In order for the director to approve a parking adjustment, it must fall within the limitations prescribed in the PTOD regulations. In addition, the director must make the findings that "in his or her opinion, such adjustment will be consistent with the purposes of the chapter, will not create undue impact on existing or potential uses adjoining the site or in the general vicinity, and will be commensurate with the reduced parking demand created by the development, including for visitors and accessory facilities where appropriate."235 In this manner, there is additional flexibility in regard to required parking.

In addition, a Transportation Demand Management (TDM) program may be prepared by a transportation consultant in order to justify a parking adjustment. A TDM may also be a condition of approval of a requested parking adjustment or may be required as through a California Environmental Quality Act (CEQA) mitigation measure to address a potentially significant parking impact. ${ }^{236}$ Frequently, TDM programs require the provision of transit passes for some or all of the residents or occupants of new buildings. These are the primary means by which the PTOD regulations ensure that new development is truly transit-oriented and meets the goal of supporting the use of public transportation.

\subsection{Current PTOD Project and Topics}

\section{Birch}

The 2650 Birch Street PTOD project is one of only two PTOD projects that have been initiated under the PTOD regulations. As currently proposed, it consists of offices on the ground floor with eight townhome-style condominium units on the floors above.

One issue on this project is the ratio of commercial floor area to residential floor area. ${ }^{237}$ The building has been designed in such a way that it would require a Senate Bill 1818 (SB 1818) affordable housing exception. The project is eligible for the exception because it is providing a certain amount of affordable housing above what would normally be required. $^{238}$

The exception would allow 2650 Birch Street to have more commercial square footage on the ground floor than would normally be allowed by the PTOD regulations. This is because while the PTOD regulations are fairly open, they do have specific floor

\footnotetext{
${ }^{235}$ City of Palo Alto, Title 18.52 of the Palo Alto Municipal Code: Zoning Ordinance, (2006), 14.

${ }^{236}$ Ibid., 17.

${ }^{237}$ Lee, interview by author.

${ }^{238}$ Ibid.
} 
area ratios for residential and nonresidential uses. ${ }^{239}$ In order to comply with the PTOD regulations, the applicant would need to put one housing unit on the ground floor. They are asking for an exception in order to have only commercial floor area on the ground floor, which would result in the commercial portion of the project exceeding the maximum allowable ratio in relation to residential floor area. The City Council will make the final decision on whether or not that is acceptable. ${ }^{240}$

In the case of the 2650 Birch Street project, which has a close proximity to the California Avenue Caltrain station, the applicant is asking for mixed-use and proximity to transit parking adjustments, which combined would result in the provision of 30 percent less parking than would normally be required. A 30 percent reduction represents the maximum parking reduction available under Chapter $18.52 .{ }^{241}$ In addition, some of the residential parking spaces are tandem spaces, so they are squeezing in as many parking spaces as they can on the site.

The zoning code does not allow tandem parking spaces to count toward the commercial use's parking requirements. This requirement is meant to keep people from blocking in other customers or workers. There are also a maximum number of tandem parking spaces that are allowed to count toward the residential use's parking requirements. The total number of proposed parking spaces technically exceeds the required number. However, the project only gets credit for a lesser amount because staff can only count a certain number of tandem spaces toward the residential use, and cannot count the additional tandem spaces toward the commercial use at all. So the result is the project is just meeting the minimum required parking for all of the uses if the 30 percent reduction is allowed. ${ }^{242}$

In addition, the applicant is proposing to use TDM strategies to further redistribute the induced demand of the project. If the project is approved, TDM will be employed and future occupants of the building will be provided with Go Passes for free or reduced cost travel on Caltrain and / or VTA buses. ${ }^{243}$ This will also serve one of the stated purposes of the PTOD regulations: supporting the use of public transportation.

In the case of the project at 2650 Birch Street, the applicant is proposing to combine five separate parcels that are zoned RM-40 (multifamily residential, with a maximum residential density of $40 \mathrm{du} / \mathrm{ac}$ ). The three single-family homes that currently occupy the site would be demolished to facilitate the development of the project. ${ }^{244}$ The project at 2650 Birch Street must also use the Context-Based Design Criteria described in the PTOD regulations. ${ }^{245}$ These regulations deal with the built form and the relation to surrounding structures and the street.

\footnotetext{
${ }^{239}$ Ibid.

${ }^{240}$ Ibid.

${ }^{241}$ Ibid.

${ }^{242}$ Ibid.

${ }^{243}$ Ibid.

${ }^{244}$ Ibid.

${ }^{245}$ Ibid.
} 
The review process for 2650 Birch began with the applicant developing initial designs for the project. In order to use the PTOD development standards, the property owner first had to initiate a rezoning process to rezone the site from its underlying zoning designation (RM-40) to PTOD. As a part of the rezoning process, the City Council adopted general guidelines for the project including density (residential and commercial), use ratios, setbacks, etc., which their approval is contingent upon. ${ }^{246}$

After the rezoning to PTOD is approved by the City Council, the project will go to the Architectural Review Board (ARB) for the board's review and approval. The applicant may also request a preliminary review by the ARB, prior to City Council review, which the applicant for the 2650 Birch Street project did. The ARB was satisfied with the design so they recommended approval with just minor comments. ${ }^{247}$ The 2650 Birch Street project was reviewed and approved by the City Council in November. The applicant will likely submit plans to the ARB before spring 2011.

\section{Senate Bill 1818}

Within the PTOD regulations, there are some opportunities for adjustments to the development standards such as the parking requirements. Also, beyond the city's allowed parking adjustments, there is Senate Bill 1818 (SB 1818: SB 1818 [Hollingsworth] Changes to Density Bonus Law - 2005), which says the more affordable housing units a developer provides the more concessions and / or incentives from the city or county they receive. These could include waivers and / or modifications to development standards such as a reduction in the number of required parking spaces, increased FAR, an openspace requirement reduction, and/or funding waivers of fees. ${ }^{248}$

It is possible to exceed the city's maximum du/ac limits through the use of SB 1818. On top of the density bonus, it is possible to earn additional concessions and incentives. If a jurisdiction does not have a specific ordinance, then the developer can generally apply for whatever he or she wants. The City of Palo Alto is working on a draft Density Bonus Ordinance, but it still must go to the PTC and City Council for review and approval. The city's density bonus ordinance is meant to prevent developers from requesting too many concessions. ${ }^{249}$ This is a significant loophole that could inadvertently undermine many of the benefits of mixed-use and transit-oriented development.

\subsection{Affordable Housing Requirements}

Palo Alto has an inclusionary housing or affordable housing requirement in its municipal code. It says that if a project consists of building five units or more, it must

\footnotetext{
${ }^{246}$ Ibid.

${ }^{247}$ Ibid.

${ }^{248}$ Babiera, interview by author.

${ }^{249}$ Ibid.
} 
provide at least 15 percent of those units as affordable units. The city may require that the developer meet this requirement either through the provision of affordable units on site, or through the payment of in-lieu fees. Also, there are housing impact fees, which are charged for new development, which go into a pot for the city to use to fund BMR affordable housing projects. ${ }^{250}$

It is very challenging in Palo Alto to develop affordable housing because land is so expensive. Oftentimes, developers need help funding affordable housing projects and the city has limited funding with which to help them. The average cost per unit to develop a Single Room Occupancy (SRO) or one-bedroom unit in Palo Alto is approximately $\$ 350,000-\$ 400,000 .^{251}$

Most of the time, developers start with the city to see if there are any available resources and then they go outside of the city to state and federal agencies to ask for tax credit allocations. Many times, affordable housing projects must pull together at least five to six sources of funding from various governmental agencies and nonprofits. That is one reason why affordable housing takes longer and is more complicated than developing market rate housing with private investors or capital. It is possible to build a mixedincome development, but one only receives credit or financial support for the percentage or number of units that are affordable. ${ }^{252}$

While there is some public sentiment against new multifamily housing, and affordable housing in general, it is not unique to Palo Alto. It is not so much the affordability of the units; it is more about the perceived impact to the neighborhood in terms of increased traffic, among other concerns. ${ }^{253}$ In other jurisdictions, impacts to schools are a big concern. That is not as much the case in Palo Alto because of how schools in Palo Alto are funded.

Palo Alto's schools receive money based on property taxes. They do not get funding from the state, based on enrollment, as most other cities in the state do. This is because Palo Alto is a basic aid district. Conversely, revenue-limit districts get more funding, for more students, so they actually want more students. ${ }^{254}$ Palo Alto schools funding comes from property taxes; so when there are more kids, schools do not get additional funding, yet their classrooms get more crowded.

Also, some residents say they do not want those people in their neighborhood. This sentiment is likely based on past affordable housing or public housing projects, which were not done very well. Public perception based on these failed projects has resulted in a stigma attached to affordable housing projects, in general, for some

\footnotetext{
${ }^{250}$ Ibid.

${ }^{251}$ Ibid.

${ }^{252}$ Ibid.

${ }^{253}$ Ibid.

${ }^{254}$ Ibid.
} 
people. ${ }^{255}$ This is another obstacle that must be overcome when planning for a variety of housing types.

However, nonprofit developers have learned a great deal from those past experiences, and because of what they have learned, they are now able to develop more pleasant and acceptable housing projects. It is human nature to be wary of change. Existing residents can become concerned when they see people who they perceive as being new in their community. However, the reality is that the majority of the people who move into affordable housing units are already living within the city where the project is located. ${ }^{256}$ As with many public perception issues, they may be addressed most effectively with increased public outreach.

Unfortunately, many people hold these ill-founded perceptions and it can be difficult to change their minds. Another strategy that developers may use to influence public perception is to bring neighbors of past projects to speak before decision-making bodies. ${ }^{257}$ The neighbors can explain that while they may have been against a project in their neighborhood at the beginning, now that a few years have gone by, they see it is really a good project. Sharing a positive affordable housing experience can help influence neighbors' perceptions.

The primary characteristic of the people who move into affordable housing developments are those who are paying more than 30 percent of their income on housing (where 30 percent to 35 percent is considered normal). Affordable housing enables these people to have more disposable income, which they can in turn use to generate economic activity in the city, which adds to the tax basis. To a market rate landlord, they may pay as much as 50 percent to 75 percent of their income, which means they do not have any money left to generate economic activity. ${ }^{258}$

In terms of affordable housing, the easiest type to build is usually senior housing, for older adults, age 62 and above. This may be because there is more funding and public acceptance for seniors. Also, seniors do not usually drive as much, and do not own as many cars. Building parking structures, especially underground, is extremely costly. ${ }^{259}$ So by building affordable senior housing, developers can get by with building fewer costly parking spaces.

Developers typically want to maximize the number of units in a development in order to bring their per-unit costs down. In Palo Alto's case, it is up to the City Council to make the final decision on projects; many times it comes down to the views of individual council members and whether or not they are strong supporters of affordable housing. ${ }^{260}$
${ }^{255}$ Ibid.
${ }^{256}$ Ibid.
${ }^{257}$ Ibid.
${ }^{258}$ Ibid.
${ }^{259}$ Ibid.
${ }^{260}$ Ibid. 


\subsection{City of Palo Alto Staff Members Interviewed for this Report}

Some of the information contained in this chapter was compiled during in-person interviews with the following City of Palo Alto Planning and Community Environment Department staff members:

Ronlando Babiera is a senior planner who works as the Housing Coordinator for the city. In this roll, Ron is the authority on housing matters as well as being responsible for updating the housing element of the City of Palo Alto's Comprehensive Plan. The interview was conducted on September 9, 2010 at Palo Alto City Hall.

Clare Campbell is a planner who works within the Current Planning section. In addition to this role, Clare is the primary planner assigned to most city-initiated projects. Clare has been with the city for nearly 10 years and was involved with the Zoning Ordinance Update (ZOU). The interview was conducted on August 31, 2010 at Palo Alto City Hall.

Elena Lee is a senior planner who works within the Current Planning section. In addition to this role, Elena was the project manager for the PTOD project at 2650 Birch Street. She has also contributed to the development of numerous policies and plans, including the California Avenue Specific Area Plan. The interview was conducted on September 9, 2010 at Palo Alto City Hall.

Roland Rivera is a senior planner who works within the Advanced Planning section. In addition to this role, Roland is an expert in quantitative analysis and is responsible for compiling much of the data that the department uses for planning and reporting activities, including the RHNA. Roland has been with the city for more than 10 years and is currently involved with the comprehensive plan update. The interview was conducted on August 31, 2010 at Palo Alto City Hall.

Curtis Williams is the Director of the City of Palo Alto Planning and Community Environment Department. This department includes staff organized under the Current Planning, Advanced Planning, Building, Transportation, and Code Enforcement sections. In his role as Director, Curtis is responsible for the day-to-day operations of the department as well as coordinating numerous special projects. The interview was conducted on September 27, 2010 at Palo Alto City Hall. 


\section{CHAPTER 6: FINDINGS, RECOMMENDATIONS, AND CONCLUSION}

The main purpose of this report is to recommend how the City of Palo Alto should revise its California Avenue PTOD Combining District regulations to more effectively support public transit use and provide a wider variety of housing types, commercial, retail, and limited office uses.

The findings and recommendations contained in this chapter are based on the best practices in TOD as determined by a review of existing studies on TOD. In addition, interviews were conducted with City of Palo Alto staff to ensure that recommendations are relevant and applicable to Palo Alto's unique conditions. This chapter begins with a review of the public perception toward development in Palo Alto in general. One must first understand local perceptions to ensure the intent of this report's recommendations are appropriate and valid. Next, the findings of this report are reviewed, followed by a list of specific recommendations for changes to current city policies and programs. Finally, the conclusion section closes the report.

\section{Public Perception}

There is a history of negative public perception toward new development in Palo Alto. Much of the sentiment against new development may be based on the skyrocketing growth the city (like elsewhere in the Bay Area and the country) experienced in the 1950s and 1960s. Since that time, the city has initiated efforts to restrict growth such as placing a cap on commercial square footage and height in the downtown area.

There is still some concern about runaway growth, but there is also a growing public acceptance of the benefits of higher-density, mixed-use and transit-oriented development. These benefits include creating communities that are livelier, with mixed uses, that reduce travel trips and increase opportunities for affordable housing and housing of all types, including for seniors and young professionals. ${ }^{261}$ The Palo Alto Central mixed-use development shown in Figure 8 abuts the California Avenue Caltrain station and is an example of this form.

${ }^{261}$ Williams, interview by author. 


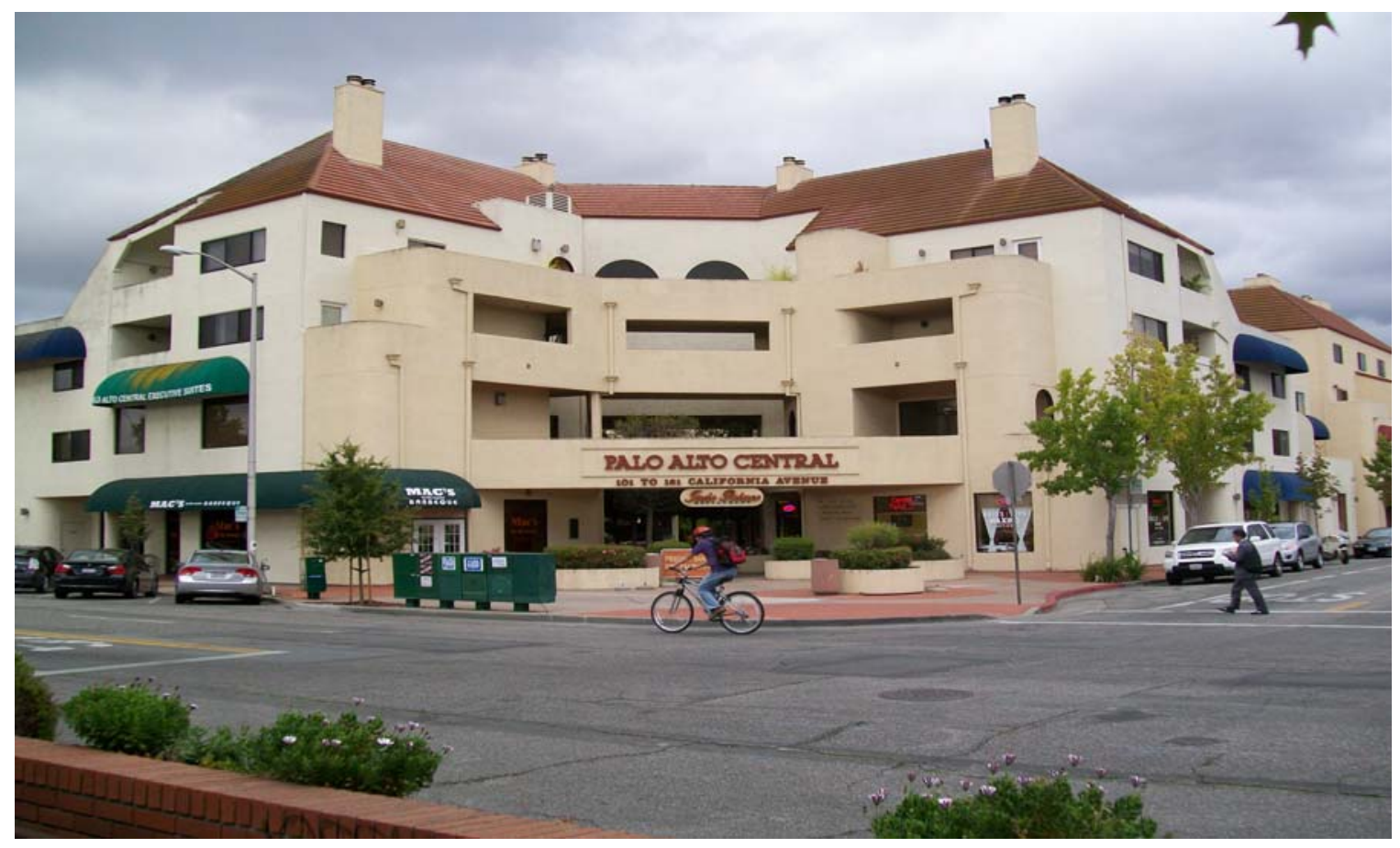

Figure 8: Palo Alto Central mixed-use development abutting the California Avenue station. Photograph by author.

The California Avenue area has experienced rapid change and growth in the past decade. As should be expected, there is some polarization that is occurring within the community. Residents at community meetings have said things such as, I used to run and play in the fields that were here (indicating the built-up area surrounding California Avenue). Some of them believe that that memory is what California Avenue should always be. For example, they perceive the California Avenue area as a lower-density, semi-rural, place with eclectic shops and mom and pop shops, not the big franchises, and that is the way they like it. ${ }^{262}$ However, this may not reflect the realities of the changing neighborhood and region.

Historically, Mayfield and its residents were perceived as somewhat of a poor cousin to Palo Alto. The newest, most popular, retail shops would always go to University Avenue or the Stanford Shopping Center and lesser shops would locate at Mayfield. Also, there were more industrial businesses near Mayfield and the train depot, as opposed to the downtown University Avenue area. ${ }^{263}$ It is important to be aware of these perceptions to ensure that plans and policies will result in future development that respects the community's history and builds on the sense of place as opposed to destroying it.

Parking is another topic that holds strong public perceptions. The city owns many of the largest vacant parcels (in the form of surface parking lots) in the California Avenue

\footnotetext{
${ }^{262}$ Rivera, interview by author.

${ }^{263}$ Staiger, interview by author.
} 
area. There is a fear from some merchants that if the city redevelops the surface parking lots, then customers will not come because they do not like parking in structured parking. They feel their customers perceive parking garages as being less convenient, which will result in fewer customers. ${ }^{264}$ However, putting in structured parking and other infrastructure could help to facilitate redevelopment in the area and could attract more businesses and customers.

That sentiment is not only from area business owners. Staff also hears from community members in the surrounding residential neighborhoods who see California Avenue as a neighborhood center. They feel that California Avenue is intended for local residents and local employees to use, and it was not intended to be a regional draw like the downtown Palo Alto (University Avenue) area. That is another reason some members of the community are against rapid redevelopment and a higher intensity of uses, because they do not want to see the character of the California Avenue area change. That presents another policy question: Does the city want to maintain the California Avenue area as a neighborhood shopping area, or does the city want to make it more of a regional draw because of its proximity to Caltrain? ${ }^{265}$

The way the PTOD was written, there seems to be a disconnect between what some current community members think California Avenue is and what the PTOD regulations allow. ${ }^{266}$ There will always be some resistance to change and growth, but the main point of contention for those who have a negative opinion of development seems to involve perceived impacts to schools, parks, and libraries. For example, they may say, If more people move here, they will crowd my schools, they will crowd my parks, they will crowd my libraries, and I do not want to have overcrowded facilities. ${ }^{267}$ Many of these perceived impacts can be addressed through carefully crafting zoning regulations and development standards that improve upon the conditions instead of making them worse.

Some community members have expressed the opinion that they do not want any additional growth and additional cars parking on their streets. But there are also community members who do see the potential for transit-oriented development in the area, provided that it does not impact the existing established community negatively. ${ }^{268}$ The public perception also varies in regard to the particular housing product being proposed, especially with smaller housing types such as studio or SRO units.

With the SRO housing type, the conversation usually turns to, What kind of people (undesirables) will start living in these small units? They are definitely not family oriented. But at the same time, people in the community say, If housing units must be built, then let's build these smaller units that may not be appropriate to families with kids, so that our schools, parks, and libraries are not impacted. ${ }^{269}$ There is a growing

\footnotetext{
${ }^{264}$ Lee, interview by author.

${ }^{265}$ Ibid.

${ }^{266}$ Rivera, interview by author.

${ }^{267}$ Ibid.

${ }^{268}$ Lee, interview by author.

${ }^{269}$ Rivera, interview by author.
} 
realization of the tradeoffs involved with TOD as opposed to the predominant singlefamily residential form.

Addressing public perception of development is a challenge because there are at least two distinct sides. There are the minority (housing advocates) and the majority in Palo Alto (anti-housing or slow-growth advocates who are usually existing SFR residents). ${ }^{270}$ There are other issues that cloud the discussion as well. Staff have heard comments from existing community members who express concerns that development might attract different populations to the area. ${ }^{271}$ But, increasingly, California Avenue is beginning to reinvent itself as a lively and inclusive, transit-oriented destination.

Staff worked with several consultants on the ZOU and PTOD regulations who provided current studies about TOD from up and down the peninsula. These studies were used to educate staff and the public about how other jurisdictions in the region were approaching TOD. In addition, these studies helped to appease a public which, at times, felt that what Palo Alto was proposing was something unusual or out of the ordinary. ${ }^{272}$ For many people, higher density has a negative connotation and just equates to more people coming into their communities. ${ }^{273}$ However, there does seem to be growing recognition of the benefits of a more urban built form.

\subsection{Findings}

Based on the research conducted in this report, several findings can be made. Perhaps the most important to acknowledge is TOD, when successfully implemented, can be a valuable tool to help cities achieve many of their goals including supporting the use of public transit, providing a variety of housing types (including affordable housing), economic vitality, a balanced job-to-housing ratio, GHG emissions reduction, and an enhanced pedestrian and bicyclist environment.

While there are many potential components of successful TOD that are available to planners, it is important to acknowledge that a cookie-cutter approach to TOD should be avoided. TOD holds the greatest potential when it is employed with a personalized approach, which respects an area's unique history and the values and ideals of its residents. Finally, as public perception of TOD shifts, it is important for a city to continually update its plans to ensure that they reflect the community's sentiment.

The findings of this report are generally consistent with the frequently cited TOD benefits (discussed in more detail in the literature review) that many practicing planners and academics accept. While there is agreement on the benefits and most important components of successful TOD, the final decisions on what standards are included in a jurisdiction's policy documents are ultimately up to the elected officials. For this reason,

\footnotetext{
${ }^{270}$ Ibid.

${ }^{271}$ Campbell, interview by author.

${ }^{272}$ Ibid.

${ }^{273}$ Staiger, interview by author.
} 
a decision maker may decide to break with a widely accepted planning principle for various political reasons.

For example, some of the recommendations that will be made in the following section of this report were proposed for inclusion in the original PTOD regulations. However, due to the political climate at the time the PTOD regulations were created, they were identified as going too far and, as a result, not being politically palatable.

Ultimately, they were removed at the direction of the decision makers at the time.

For this reason, it is important to ensure that the community and its representative elected officials are committed to actually implementing the more hard-line TOD principles. This commitment will help to ensure that the most important principles are not watered down, and that they are included in the final draft. Community opposition must be understood and addressed, to ensure that both the community and elected officials can support the most promising components of TOD. During the policy formation process, there are many stakeholders with a variety of agendas. It is important to acknowledge this fact and build consensus before pressing forward with a policy that may be viewed as outside of the norm.

Another important finding of this report is that developers are more assured of a project's prospect when a city's vision or goals for an area are clearly defined within the city's general plan and zoning ordinance. Developers must carefully evaluate local conditions, policies, and perceptions in order to execute TOD successfully. For example, developers generally would like to build less parking than zoning codes allow, especially for affordable housing projects. In the case of the PTOD district, the parking requirements are the same as for other areas of the city, and parking adjustments are at the discretion of the director. While it is possible to achieve up to a 30 percent to 40 percent reduction in required parking through this process, it provides an additional degree of uncertainty. Having a specific set parking standard within the PTOD regulations themselves could clarify the requirements.

An additional finding is that only smaller projects have been proposed, thus far, under the PTOD district regulations. Of these, it seems like the residential component has been more of an afterthought to the office or retail component. This mirrors most of the new development projects in the city, which are generally below the maximum allowed residential density. There are many reasons why developers do this. For example, some might be concerned by escalating building costs associated with building taller buildings, more stringent building code requirements, and increased limitations on other development standards. Also, developers have been reluctant to build SRO or affordable housing. The sentiment is that Manhattan-style 400 square-foot studios are not marketable in Palo Alto. To the contrary, 2,000 square-foot condos have proven to be marketable in Palo Alto.

In regards to the fact that the PTOD regulations have only been invoked twice since they were enacted, there are several findings that can be made. First, a primary reason for this is due to the recession and the economic downturn in general. The 
financial events of the past several years have dealt a blow to the housing industry and the economy in general. Secondly, many of the parcels in the California Avenue district are smaller and already developed with one- or two-story buildings. This parcel configuration and established form present obstacles to redevelopment. Developers may need to obtain several parcels to make a project work; even then, the result may not represent a very large net increase in floor area.

Furthermore, many of the parcels in the California Avenue district are currently zoned Community Commercial (CC [2]), which already affords fairly liberal FAR allowances. In that regard, the FAR standards in the PTOD regulations may not go far enough to encourage or promote redevelopment. Finally, the overlay nature of the PTOD regulations (as opposed to by right) presents another obstacle to project proponents. Developers have been reluctant to undertake the longer process of initiating a rezoning of their property to PTOD instead of just having the project reviewed by the Architectural Review Board.

In addition to promulgating regulations for the California Avenue area, the city also controls and owns most of the existing surface parking lots that are located there. These city-owned parking lots make up the majority of large vacant parcels in the area. They will play an important role in any large-scale redevelopment in the area, and the city should consider and formulate policies on how these parcels could provide momentum to private development in the area. Also, existing commercial uses on California Avenue have a hard time parking during certain hours. The city-owned surface parking lots will play an important role in addressing parking issues for existing and future businesses in the area.

\subsection{Recommendations}

Based on the research conducted in this report, the following recommendations are made on how the City of Palo Alto should revise its California Avenue PTOD Combining District regulations to further implement two of the stated goals of the PTOD regulations: (1) support use of public transportation and (2) encourage a variety of housing types, commercial, retail, and limited office uses.

The city should review and revise the land use, transportation, and housing elements of its comprehensive plan to ensure they are internally consistent with the zoning ordinance and consistent with the desires of the community, citywide. More specifically, the city should continue to work with the California Avenue neighborhood to determine if the California Avenue area will stay a neighborhood shopping area or transition to a regional center. In the case of the latter, Palo Alto should continue to plan on accommodating additional growth within the California Avenue PTOD district. This growth should be managed through the incremental revision of the development standards, where appropriate. 
If California Avenue is designated to accommodate future growth, some of the more aggressive transit-oriented standards should be reviewed for inclusion in the PTOD regulations. These include minimum residential-density requirements and/or maximum unit-size requirements to facilitate the development of a variety of smaller units, as well as maximum parking requirements. In addition, the regulations could be revised to provide even greater incentives to further encourage the provision of housing for older adults. The Parking Adjustments section should allow additional reductions in required parking. This will further support the use of public transportation (e.g., Caltrain, bus, and shuttle service).

The city should revise the PTOD regulations to further encourage the provision of housing for older adults. Older adults drive less and use transit more than the rest of the population. They require less parking, do not have as large an impact on some city services like schools, and could benefit from the close proximity of the PTOD district to Stanford's medical facilities and services. The provision of housing and facilities for older adults should be further prioritized.

The city should use the current economic climate and resulting development slowdown as an opportunity to revise policies to ensure that when development picks up, the city will be heading in the right direction. By having a clear vision and policies in place, a kneejerk reaction to a future development boom can be avoided; instead, the growth can move in the desired direction.

The city should revisit the boundary of the California Avenue PTOD district to determine if it could be adjusted to be larger or smaller in light of the high affinity for walking and bicycling present in the local population. The city may also consider extending the district boundary to capture both sides of El Camino Real. The existing zoning already allows increased density for mixed-use projects, and the VTA's Bus Rapid Transit Line 522 has been identified for future incremental expansion.

The city should consider making the PTOD regulations by right as opposed to an overlay. This would result in a greatly streamlined review process that would save developers time and money and provide a clearer roadmap through the entitlement process. A streamlined process would not necessarily result in less community involvement and control for the decision makers; it would only mean the development standards contained within the PTOD regulations would need to be more carefully crafted. As always, there should be plenty of room for discretion to ensure that there is flexibility within the regulations to provide for differences in sites.

The city should jumpstart redevelopment by revising the zoning ordinance to stimulate investment in targeted locations, investing in public spaces, and offering incentives for private developers. Also, the city can take the lead by applying for grants from other agencies to help pay for the cost of upgrading public infrastructure and possibly by funding public parking structures. Throughout this process, the city should actively work to keep the community informed of current planning topics, and to manage 
the public perception of redevelopment, through a robust public participation and education program.

The City of Palo Alto should continue to work closely with its longtime neighbor, Stanford University, to synergize land use, transportation planning, development efficiencies, and other collaboration to ensure that future growth is mutually beneficial and sustainable. This will include a continual evaluation of residential parking permit policies to determine if they may work to address neighbors' concerns about spillover parking by employees and customers of the California Avenue area and Stanford Research Park.

Most importantly, any new development in the California Avenue area should embrace Mayfield's eclectic culture and historic roots, perhaps through the further provision of public art, including murals. The California Avenue area has a separate and distinct history from Palo Alto proper; it should be embraced, not concealed or played down.

\subsection{Conclusion}

Transit-oriented development holds great promise for being a tool which can be successfully employed to bring about positive changes to the built environment. While it is clear that certain aspects of TOD, such as increased density and decreased environmental impacts, provide quantifiable benefits, there are other aspects that are more difficult to interpret. For example, with increased density there often comes community opposition from existing neighbors.

The City of Palo Alto has already taken many steps toward making a transitoriented district a reality for the California Avenue area. It is important to acknowledge all of the work that has gone into the effort thus far. Projects using the California Avenue PTOD regulations can successfully accomplish two of its stated purposes: (1) supporting the use of public transportation, and (2) providing a wide variety of housing types. This new construction can be accomplished while also respecting the current community's desires of maintaining the same level of service at schools, parks, and libraries.

However, it is important to acknowledge the fact that planners' best intentions are always at the mercy of the elected decision makers. Decision makers are accountable and held responsible by the public, which can sometimes lead to kneejerk reactions. In that way, the PTOD regulations could be described as having been developed at a bad time, or under an unfortunate political climate. Therefore, it is important for developers to have a clear picture of whether there is support for a project, or not, before they get too far along. The leanings of individual decision makers can mean everything if a specific project or proposal makes it through the process. No matter how good a project may be, a commissioner or council member could be totally opposed. 
Another essential part of the solution will include leveraging the redevelopment of the city-owned surface parking lots in the California Avenue area. It will be difficult to provide more parking at California Avenue until the city can facilitate some of these infrastructure improvements in the area via grants and other funding. The city will eventually need to address its lack of workforce housing through providing incentives to developers to build smaller housing units that may not have as many impacts as larger units. Perhaps the model needs to change a little bit as far as the housing type's people have come to expect as being developed and desired in Palo Alto and elsewhere.

While TOD certainly results in lower automobile trip generation rates, VMT, and emissions, there are still reasons that TOD may not be the best solution in all cases. For example, many low-density or remote areas do not readily lend themselves to this development form. Also, some communities are based specifically on the opposite ideals as TOD. When dealing with development and people, it is hard to reach a conclusion that fits every circumstance, every time. Perhaps the biggest lesson we learn from the existing research on TOD is that more often than not, the best way to proceed is to look to past experiences as a starting point and try to tailor a specific solution for the particular community's needs.

The big limitation of this paper is that it only provides a snapshot of the current status of the City of Palo Alto's PTOD regulations. As Palo Alto and its residents change and grow over time, public perceptions and desires also change. In this way, there will be an almost limitless opportunity for future research and revision to the city's comprehensive plan, PTOD regulations, and municipal code. 


\section{BIBLIOGRAPHY}

Air Resources Board. “Air Quality and Transportation Planning.” Air Resources Board. http://www.arb.ca.gov/planning/planning.htm (accessed May 13, 2010).

. "ARB Mission and Goals.” Air Resources Board.

http://www.arb.ca.gov/html/mission.htm (accessed May 13, 2010).

_. "Climate Change Program." Air Resources Board.

http://www.arb.ca.gov/cc/cc.htm (accessed May 13, 2010).

. "Introduction to the Air Resources Board." Air Resources Board.

http://www.arb.ca.gov/html/brochure/arb.htm (accessed May 13, 2010).

—_. "Senate Bill 375 - Regional Targets.” Air Resources Board.

http://www.arb.ca.gov/cc/sb375/sb375.htm (accessed May 13, 2010).

Arrington, G. B., and Robert Cervero. "Effects of TOD on Housing, Parking, and Travel.” Transit Cooperative Research Program 128 (2008): 1-67.

Association of Bay Area Governments. "ABAG History.” Association of Bay Area Governments. http://www.abag.ca.gov/overview/history.html (accessed May 13, 2010).

. "ABAG Overview.” Association of Bay Area Governments.

http://www.abag.ca.gov/overview (accessed May 13, 2010).

__ "ABAG Projections 2007: Executive Summary.” Association of Bay Area Governments. http://www.abag.ca.gov/planning/currentfcst/summary1.html (accessed January 15, 2009).

_ _ "Bay Area Challenges.” Association of Bay Area Governments. http://www.abag.ca.gov/overview/challenges.html (accessed May 13, 2010).

_. "Latest News." Association of Bay Area Governments. http://www.abag.ca.gov/planning/housingneeds/ (accessed May 13, 2010).

Babiera, Ronlando, Senior Planner. Interview by author. City of Palo Alto Planning and Community Environment Department, Palo Alto, CA. September 9, 2010.

Badoe, Daniel A., and Eric J. Miller. "Transportation Land-Use Interaction: Empirical Findings in North America, and their Implications for Modeling." Transportation Research D 5 (2000): 235-263. 
Bay Area Air Quality Management District. “Bicycle Facility Program.” Bay Area Air Quality Management District. http://www.baaqmd.gov/Divisions/StrategicIncentives/Bicycle-Facility-Program.aspx (accessed May 13, 2010).

_. "Planning, Rules and Research Division." http://www.baaqmd.gov/Divisions/Planning-and-Research.aspx (accessed May 13, 2010).

__. "Smart Growth.” Bay Area Air Quality Management District. http://www.baaqmd.gov/Divisions/Planning-and-Research/Smart-Growth.aspx (accessed May 13, 2010).

_. "The Air District.” Bay Area Air Quality Management District. http://www.baaqmd.gov/The-Air-District.aspx (accessed May 13, 2010).

Bhat, Chandra R., and Jessica Y. Guo. "A Comprehensive Analysis of Built Environment Characteristics on Household Residential Choice and Auto Ownership Levels.” Transportation Research B 41(2007): 506-526.

Blanco, Hilda, Marina Alberti, Ann Forsyth, Kevin Krizek, Daniel A. Rodriguez, Emily Talen, and Cliff Ellis. "Hot, Congested, journal Crowded and Diverse: Emerging Research Agendas in Planning.” Progress in Planning 71 (2009): 153-205.

Boarnet, Marlon, and Nicholas S. Compin. "Transit-Oriented Development in San Diego County: The Incremental Implementation of a Planning Idea." Journal of the American Planning Association 65 (Winter 1999): 1-37.

Bort, Joseph P. "Fact Sheet.” Metropolitan Transportation Commission. http://www.mtc.ca.gov/legislation/SB375_Fact_Sheet.pdf (accessed May 13, 2010).

California Department of Transportation. "Statewide Transit-Oriented Development Study: Factors for Success." http://transitorienteddevelopment.dot.ca.gov/PDFs/Statewide\%20TOD\%20Study \%20Final\%20Report\%20Sept.\%2002.pdf (accessed January 15, 2009).

California High Speed Rail Authority. "News and Facts." State of California. http://www.cahighspeedrail.ca.gov/news.asp?type=faqs (accessed May 13, 2010).

Caltrain. "Caltrain 2025 (Electrification)." Caltrain. http://www.caltrain.com/caltrain2025.html (accessed May 13, 2010).

Caltrans. “About Caltrans.” California Department of Transportation. http://www.dot.ca.gov/aboutcaltrans.htm (accessed May 13, 2010). 
_ . "California Transportation Plan (CTP)." California Department of Transportation. http://www.dot.ca.gov/hq/tpp/offices/osp/ctp.html (accessed May 13, 2010).

__ . "Caltrans Mission and Goals.” California Department of Transportation. http://www.dot.ca.gov/hq/paffairs/about/mission.htm (accessed May 13, 2010).

__ . "Community Based Transportation Planning." California Department of Transportation. http://www.dot.ca.gov/hq/tpp/offices/ocp/cbtp.html (accessed May 13, 2010).

_ . "Office of Regional and Interagency Planning." California Department of Transportation. http://www.dot.ca.gov/hq/tpp/offices/orip/index.html (accessed May 13, 2010).

_ . "Regional Blueprints." California Department of Transportation. http://calblueprint.dot.ca.gov/ (accessed May 13, 2010).

Campbell, Clare, Planner. Interview by author. City of Palo Alto Planning and Community Environment Department, Palo Alto, CA. August 31, 2010.

Cervero, Robert. "Built Environments and Mode Choice: Toward a Normative Framework.” Transportation Research D 7 (2002): 265-284.

_ . "Efficient Urbanization: Economic Performance and the Shape of the Metropolis.” Urban Studies 38 (2001): 1651-1671.

_ . "Jobs-Housing Balance Revisited.” Journal of the American Planning Association 62 (Autumn 1996): 492-511.

_ . "Rail Transit and Joint Development." Journal of the American Planning Association 60 (Winter 1994): 83-94.

—_ "Road Expansion, Urban Growth, and Induced Travel: A Path Analysis." Journal of the American Planning Association 69 (Spring 2003): 145-163.

_ . "Transit-Oriented Development in the United States: Experiences, Challenges, and Prospects.” Transit Cooperative Research Program 102 (2004): 1-534.

Cervero, Robert, Christopher Ferrell, and Steven Murphy. "Transit-Oriented Development and Joint Development in the United States: A Literature Review.” Transit Cooperative Research Program 52 (October 2002): 1-144.

Cervero, Robert, and Michael Duncan. "Neighborhood Composition and Residential Land Prices: Does Exclusion Raise or Lower Values?” Urban Studies 41 (February 2004): 299-315. 
—. "Which Reduces Vehicle Travel More: Jobs Housing Balance or Retail-Housing Mixing?” Journal of the American Planning Association 72 (Autumn 2006): 475490.

Cervero, Robert, and Roger Gorham. "Commuting in Transit Versus Automobile Neighborhoods.” Journal of the American Planning Association 61 (Spring 1995): 210-226.

Chatman, D. G. "Deconstructing Development Density: Quality, Quantity and Price Effects on Household Non-Work Travel.” Transportation Research A 42 (2008): 1008-1030.

City of Palo Alto Planning and Community Environment Department. Enhancing the New Century: Palo Alto Comprehensive Plan 1998-2010. (1998).

- Title 18 of the Palo Alto Municipal Code: City of Palo Alto Zoning Ordinance. (2006).

- Title 18.34 of the Palo Alto Municipal Code: Pedestrian and Transit-Oriented Development Combining District Regulations. (2006).

—. Staff Report: 2650 Birch Street, by Elena Lee. August 2010.

Davis, Amelie Y., Bryan C. Pijanowski, Kimberly Robinson, and Bernard Engel. “The Environmental and Economic Costs of Sprawling Parking Lots in the United States.” Land Use Policy 27 (2010): 255-261.

Focus. “About Focus.” Focus. http://www.bayareavision.org/initiatives/ (accessed May 13, 2010).

Gomez-Ibanez, Jose A., Marlon G. Boarnet, Dianne R. Brake, Robert B. Cervero, Andrew Cotugno, Anthony Downs, Susan Hanson, Kara M. Kockelman, Patricia L. Mokhtarian, Rolf J. Pendall, Danilo J. Santini, and Frank Southworth. "Driving and the Built Environment: The Effects of Compact Development on Motorized Travel, Energy Use, and CO2 Emissions.” National Research Council. Transportation Research Board 298 (2009): 1-240.

Gordon, Peter, and Harry W. Richardson. “Are Compact Cities a Desirable Planning Goal?” Journal of the American Planning Association 63 (Winter 1997): 95-107.

Handy, Susan. "Regional Transportation Planning in the US: An Examination of Changes in Technical Aspects of the Planning Process in Response to Changing Goals.” Transport Policy 15 (2008): 113-126. 
_. "Smart Growth and the Transportation Land-Use Connection: What Does the Research Tell Us?” International Regional Science Review 28 (April 2005): 146167.

Handy, Susan, Xinyu Cao, and Patricia Mokhtarian. "Correlation or Causality between the Built Environment and Travel Behavior? Evidence from Northern California." Transportation Research D 10 (2005): 427-444.

Hendricks, Sara J., and Julie Goodwill. "Building Transit-Oriented Development in Established Communities.” National Center for Transit Research. http://www.nctr.usf.edu/pdf/473-135.pdf (accessed January 15, 2009): 1-76.

Iacono, Michael, Kevin Krizek, and Ahmed El-Geneidy. “Access to Destinations: How Close is Close Enough? Estimating Accurate Distance Decay Functions for Multiple Modes and Different Purposes.” Minnesota Department of Transportation. http://www.lrrb.org/PDF/200811.pdf (accessed January 15, 2009): $1-76$.

Inam, Aseem, Jonathan Levine, and Richard Werbel. "Developer-Planner Interaction in Transportation and Land Use Sustainability.” Mineta Transportation Institute 0121 (June 2002): 1-70.

Karash, Karla H., Matthew A. Coogan, Thomas Adler, Chris Cluett, Susan A. Shaheen, Icek Aizen, and Monica Simon. "Understanding How Individuals Make Travel and Location Decisions: Implications for Public Transportation.” Transit Cooperative Research Program 123 (2008): 1-147.

Khattak, Asad J., and Daniel Rodriguez. "Travel Behavior in Neo-Traditional Neighborhood Developments: A Case Study in USA.” Transportation Research A 39 (2005): 481-500.

Lee, Elena, Senior Planner. Interview by author. City of Palo Alto Planning and Community Environment Department, Palo Alto, CA. September 9, 2010.

Levine, Jonathan, and Aseem Inam. "The Market for Transportation Land-use Integration: Do Developers Want Smarter Growth than Regulations Allow?" Transportation 31 (November 2004): 409-427.

Li, Chia-Nung, and Tsung-Yu Lai. "Why Should Cities Change from DOT to TOD?" Institution of Civil Engineers. Transport 162 (May 2009): 71-78.

Lin, J. J., and C. C. Gau. "A TOD Planning Model to Review the Regulation of Allowable Development Densities around Subway Station.” Land Use Policy 23 (2006): 353-360. 
Lund, Hollie. "Reasons for Living in a Transit-Oriented Development, and Associated Transit Use.” Journal of the American Planning Association 72 (Summer 2006): $1-144$.

Lund, Hollie, Richard W. Willson, and Robert Cervero. "A Re-evaluation of Travel Behavior in California TODS.” Journal of Architectural and Planning Research 23 (Autumn 2006): 247-263.

Metropolitan Transportation Commission. “About MTC.” Metropolitan Transportation Commission. http://www.mtc.ca.gov/about_mtc/about.htm (accessed May 13, 2010).

_. "Glossary of Transportation Planning Acronyms and Terms.” Metropolitan Transportation Commission. http://www.mtc.ca.gov/library/glossary.htm (accessed May 13, 2010).

—_ "Smart Growth / Transportation for Livable Communities." Metropolitan Transportation Commission. www.mtc.ca.gov/planning/smart_growth/ (accessed May 13, 2010).

One Bay Area. "Background.” One Bay Area. http://www.onebayarea.org/background.htm (accessed May 13, 2010).

__. "Spotlight.” One Bay Area. http://www.onebayarea.org/spotlight.htm (accessed May 13, 2010).

Renne, John L. "From Transit-Adjacent to Transit-Oriented Development.” Local Environment 14 (January 2009): 1-15.

Renne, John L., and Jan S. Wells. “Transit-Oriented Development: Developing a Strategy to Measure Success.” National Cooperative Highway Research Program 294 (February 2005): 1-32.

Rhindress, Mindy, Frank Lynch, Susan Bregman, Rose E. Reichman, Nancy J. Coopersmith, and John A. Dunning. "Understanding How to Motivate Communities to Support and Ride Public Transportation.” Transit Cooperative Research Program 122 (2008): 1-92.

Rivera, Roland, Senior Planner. Interview by author. City of Palo Alto Planning and Community Environment Department, Palo Alto, CA. August 31, 2010.

Salon, Deborah, Daniel Sperling, Alan Meier, Sinnott Murphy, Roger Gorham, and James Barrett. "City Carbon Budgets: A Proposal to Align Incentives for Climate Friendly Communities.” Energy Policy 38 (2010): 2032-2041. 
San Francisco Bay Conservation and Development Commission. "BCDC’s Mission.” State of California. http://www.bcdc.ca.gov/mission.shtml (accessed May 13, 2010).

Shore, William B. "Land-Use, Transportation and Sustainability.” Technology in Society 28 (2006): 27-43.

Southworth, Frank. "On the Potential Impacts of Land Use Change Policies on Automobile Vehicle Miles of Travel.” Energy Policy 29 (2001): 1271-1283.

Staiger, Steve, City Historian. Interview by author. City of Palo Alto Library Department, Palo Alto, CA. August 12, 2010.

Stone Jr., Brian, Adam C. Mednick, Tracey Holloway, and Scott N. Spak. “Is Compact Growth Good for Air Quality?” Journal of the American Planning Association 73 (2007): 404-418.

VTA. "El Camino.” Santa Clara Valley Transportation Authority. http://www.vta.org/brt/el_camino.html (accessed May 13, 2010).

—_ "History.” Santa Clara Valley Transportation Authority. http://www.vta.org/inside/about/index.html (accessed May 13, 2010).

__ "Memorandum.” Santa Clara Valley Transportation Authority. http://www.vta.org/projects/CDT_Capital_Application.pdf (accessed May 13, 2010).

_ . “Transit-Oriented Development (TOD) Program.” Santa Clara Valley Transportation Authority. http://www.vta.org/projects/tod.html (accessed May 13, 2010).

Weinstein-Agrawal, Asha, Marc Schlossberg, and Katja Irvin. "How Far, by Which Route and Why? A Spatial Analysis of Pedestrian Preference.” Journal of Urban Design 13 (February 2008): 81-98.

White, Mark S., and James B. McDaniel. “The Zoning and Real Estate Implications of Transit-Oriented Development.” Transit Cooperative Research Program 12 (January 1999): 1-51.

Wikipedia. “California High-Speed Rail.” Wikipedia. http://en.wikipedia.org/wiki/California_High-Speed_Rail (accessed May 13, 2010).

_ . "Caltrain.” Wikipedia. http://en.wikipedia.org/wiki/Caltrain (accessed May 13, 2010). 
—_. “Global Warming Solutions Act of 2006.” Wikipedia. http://en.wikipedia.org/wiki/Global_Warming_Solutions_Act_of_2006 (accessed May 13, 2010).

Williams, Curtis, Department Director. Interview by author. City of Palo Alto Planning and Community Environment Department, Palo Alto, CA. September 27, 2010.

Winslow, Ward. Palo Alto: A Centennial History. Palo Alto, CA: Palo Alto Historical Association, 1993.

Winston, Clifford, and Vikram Maheshri. "On the Social Desirability of Urban Rail Transit Systems.” Journal of Urban Economics 62 (2007): 362-382. 
APPENDIX 1

CALIFORNIA AVE. PTOD DISTRICT BOUNDARY MAP. Map by Roland Rivera.

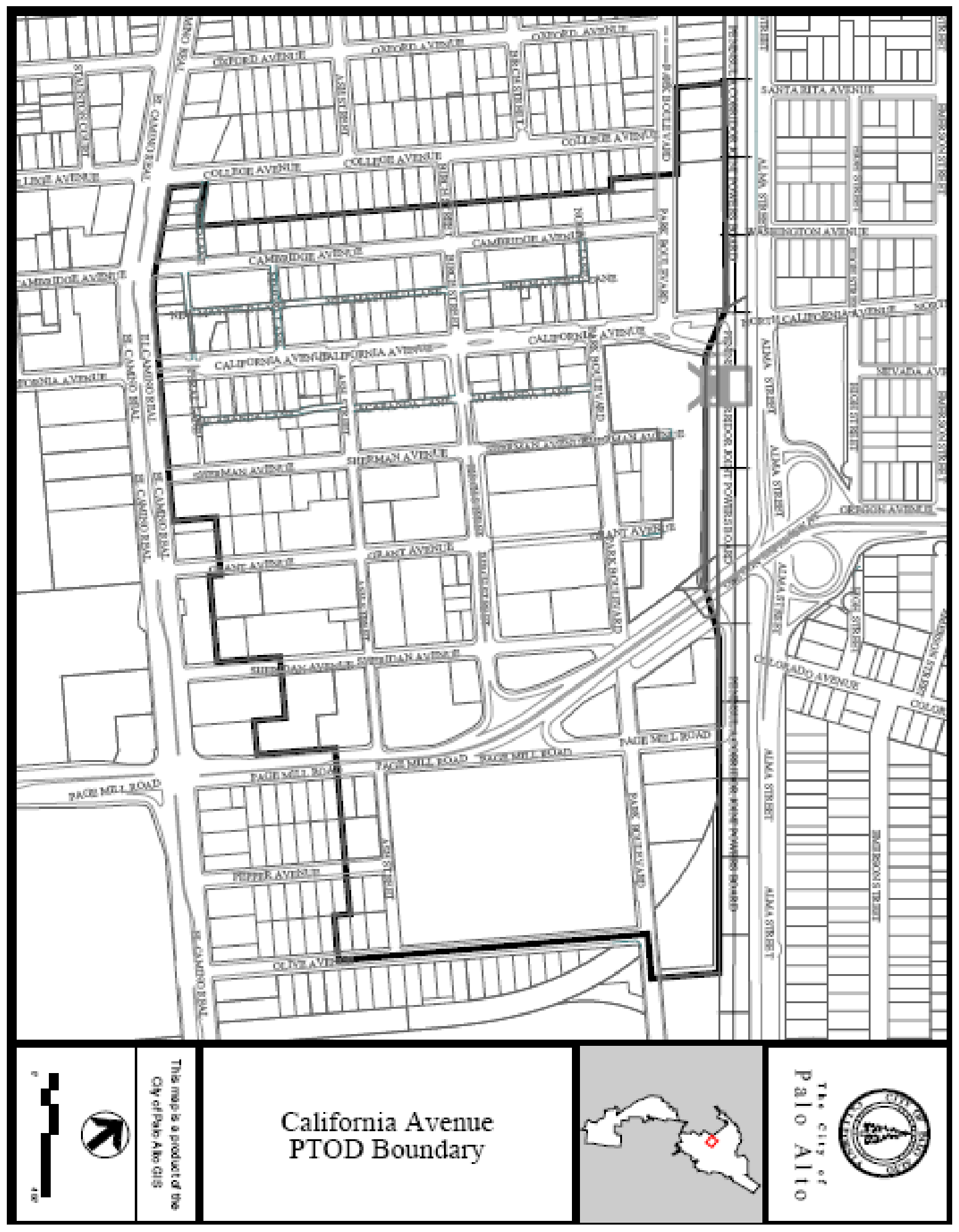




\section{APPENDIX 2}

\section{ACRONYMS}

AB 32 - Assembly Bill 32

ABAG - Association of Bay Area Governments

APS - Alternative Planning Strategy

ARB - Architectural Review Board

BAAQMD - Bay Area Air Quality Management District

BCDC - Bay Conservation and Development Commission

BFP - Bicycle Facility Program

BMR - Below Market Rate

BRT - Bus Rapid Transit

CARB - California Air Resources Board

CBTP - Community Based Transportation Planning

CDT - Community Design and Transportation

CEQA - California Environmental Quality Act

CHSRA - California High-Speed Rail Authority

CMA - Congestion Management Agency

COG - Councils of Governments

CTC - California Transportation Commission

CUP - Conditional Use Permit

EMU - Electric Multiple Unit

EPA - Environmental Protection Agency

FAR - Floor Area Ratio

GHG - Green House Gases

HCD - California Department of Housing and Community Development

ISTEA - Intermodal Surface Transportation Efficiency Act

LOS - Level of Service

MPO - Metropolitan Planning Organization

MTC - Metropolitan Transportation Commission

PAMC - Palo Alto Municipal Code

PC - Planned Community

PCJPB - Peninsula Corridor Joint-Powers Board

PDA - Priority Development Area

PTC - Planning and Transportation Commission

PTOD - Pedestrian and Transit-Oriented Development

RHNA - Regional Housing Needs Assessment

RTP - Regional Transportation Plan

RTPA - Regional Transportation Planning Agency

SAFETEA-LU - Safe, Accountable, Flexible, Efficient Transportation Equity Act: A Legacy for Users

SB 375 - Senate Bill 375

SB 1818 - Senate Bill 1818

SCS - Sustainable Communities Strategy

SJSU - San José State University 
SRO - Single Room Occupancy

STIP - State Transportation Improvement Program

TDM - Transportation Demand Management

TEA 21 - Transportation Equity Act for the 21st Century

TIP - Transportation Improvement Program

TLC - Transportation for Livable Communities

TOD - Transit-Oriented Development

TRB - Transportation Research Board

TRIS - Transportation Research Information Service

VHT - Vehicle Hours Traveled

VMT - Vehicle Miles Traveled

VTA - Valley Transportation Authority

ZOU - Zoning Ordinance Update 


\section{APPENDIX 3}

\section{IN-PERSON INTERVIEW QUESTIONS}

1. Can you tell me anything about the CPA or Mayfield's history and, more specifically, about the expansion/growth that has occurred there? Can you tell me anything about the public perception of transportation, transit, growth, and development?

2. Are you familiar with the concept of Transit-Oriented Development (TOD)?

3. Are you familiar with the CPA's PTOD regulations and Comprehensive Plan directives?

4. Can you provide any background information on the CPA's PTOD regulations?

5. Can you tell me anything about the rezoning process to allow PTOD?

6. One of the stated purposes of the CPA's PTOD regulations is, "encourage a variety of housing types, commercial, retail, and limited office uses." Do you think this stands in opposition to the current anti-development sentiment of some residents of the city? If so, has the anti-growth sentiment always been present in Palo Alto? When did it come about and why?

7. Do you think city residents would have a more favorable view of PTOD in the vicinity of the California Avenue train station or the University Avenue train station,, and why?

8. Are you familiar with the CPA's Comprehensive Plan, housing element, or other special area plans?

9. Do you have any suggestions on how the city could improve the public perception of development and TOD specifically? Are there any parallels from the historical perspective?

10. Palo Alto residents' views on transit, transportation, and growth have changed over time. Are you aware of any events that may have facilitated these changed perceptions or public sentiment shift?

11. Do you know of any datasets, or specific charts, graphs, or illustrations that may be available and pertinent to this research?

12. Do you know of any other people who may be able to tell me more about this topic?

13. Would it be okay to contact you again in the future as my research progresses? 
14. I understand that you were involved with the development of the PTOD regulations. Can you talk about what the political climate was at the time and what the impetus was for PTOD? Was it a Comprehensive Plan directive?

15. Where the PTOD regulations say "a variety of housing types," does that refer to housing product type (condo, SFR, apartments, etc.), income levels, or differentsized units? The code does not appear to be very specific in that regard. Is this on purpose, to allow greater flexibility?

16. One aspect of the PTOD regulations is that you have to apply for it as opposed to by right. What was the thinking behind this?

17. For this RHNA cycle, the city has been allocated 2,860 units, which the Council has specified should be near transit and fixed rail stations as well as El Camino Real. Do you know if a similar direction was given to staff in the past?

18. Was there any talk about establishing minimum densities or maximum parking allowances?

19. The California Avenue area is already fairly built up and there are primarily smaller parcels there. Do you think that presents a challenge to redevelopment there?

20. The Fry's site has historically been a job center, packing center, soda bottling, supermarket, Fry's. It is currently zoned residentially, but does the city want it to revert to residential? Do we want to maintain the California Avenue area as a neighborhood shopping area or do we want to make it more of a regional draw because of its proximity to Caltrain?

21. The city owns most of the surface parking lots in the area. How might they factor into California Avenue's future?

22. Was there much pushback from community members at the time of PTOD or in general in the city? Do you think traffic really is the main concern for new development in general?

23. Do you think there will be opportunities to revisit the PTOD regulations sometime in the future? How big a role do you think the political climate played, at the time, as far as the conversion of commercial/industrial sites to housing with the effectiveness of the PTOD regulations?

24. Almost all negative perceptions of growth during this time (1950-1960) were traffic related. Do you think this is still true today? 